\title{
Research Commons
}

\section{http://researchcommons.waikato.ac.nz/}

\section{Research Commons at the University of Waikato}

\section{Copyright Statement:}

The digital copy of this thesis is protected by the Copyright Act 1994 (New Zealand).

The thesis may be consulted by you, provided you comply with the provisions of the Act and the following conditions of use:

- Any use you make of these documents or images must be for research or private study purposes only, and you may not make them available to any other person.

- Authors control the copyright of their thesis. You will recognise the author's right to be identified as the author of the thesis, and due acknowledgement will be made to the author where appropriate.

- You will obtain the author's permission before publishing any material from the thesis. 


\title{
LONG TERM NITRATE REMOVAL IN A DENITRIFICATION WALL
}

\author{
A thesis \\ submitted in fulfilment \\ of requirements for the degree \\ of
}

Master of Philosophy in Earth and Ocean Sciences

at

The University of Waikato

by

LAUREN M. LONG



THE UAVERSITY OF WAIKATO

Te Whare Wananga o Waikato

The University of Waikato

2011 


\begin{abstract}
Nitrogen $(\mathrm{N})$ inputs to groundwater are one of the most widespread environmental problems globally. However, as $\mathrm{N}$ is important for crop production to support the current global population, it is difficult to limit $\mathrm{N}$ input to an extent where groundwater contamination is completely avoided. Researchers have been testing new ways to remove $\mathrm{N}$ (in the form of nitrate $\left(\mathrm{NO}_{3}{ }^{-}\right)$) from groundwater, primarily through enhancing microbial denitrification. One technology utilizing this microbial process is a denitrification wall, which is an inexpensive, low-maintenance technology compared to other options to treat $\mathrm{NO}_{3}{ }^{-}$-contaminated groundwater.

Denitrification walls have been shown to be effective for removing $\mathrm{NO}_{3}{ }^{-}$from groundwater through denitrification for seven years in New Zealand, nine years in Iowa, and 15 years in Canada; however, long-term data on the efficacy of denitrification walls remain limited. In order to understand how these systems function in the long term, the performance of a New Zealand denitrification wall installed in 1996 was examined. Field sampling was carried out during the winter of 2010 at the denitrification wall at Bardowie Farm in Cambridge, New Zealand. This farm had received relatively high $\mathrm{N}$ inputs from spray-irrigation of effluent from the nearby Hautapu Dairy Factory for over 30 years.
\end{abstract}

The denitrification wall was originally constructed by mixing $40 \mathrm{~m}^{3}$ Pinus radiata sawdust with soil down to a depth of $1.5 \mathrm{~m}$ where it intercepted groundwater flow. Groundwater samples were collected from wells installed upslope and within the wall and samples were analyzed for $\mathrm{NO}_{3}{ }^{-}$concentrations on five occasions. Soil samples were collected on four occasions from below the water table and analyzed for denitrifying enzyme activity (DEA), total carbon (C), available C, and microbial biomass $\mathrm{C}$. Results were compared to previous measurements.

Groundwater $\mathrm{NO}_{3}{ }^{-}$concentrations entering the wall averaged $2.6 \mathrm{mg} \mathrm{N} \mathrm{L}^{-1}$, which was a decrease from 2002 where $\mathrm{NO}_{3}{ }^{-}$entered the wall at an average of $9 \mathrm{mg} \mathrm{N} \mathrm{L}^{-1}$. Despite this decrease, $\mathrm{NO}_{3}{ }^{-}$concentrations within the wall averaged $0.2 \mathrm{mg} \mathrm{N} \mathrm{L}^{-1}$, which corresponded to $92 \% \mathrm{NO}_{3}{ }^{-}$removal. DEA rates in the wall were nearly as high as the first year of construction. In contrast, total $\mathrm{C}$ and microbial biomass $\mathrm{C}$ had decreased by half, while available $\mathrm{C}$ remained the same as measured two years after construction. Denitrification in the wall remained $\mathrm{NO}_{3}{ }^{-}$limited suggesting that $\mathrm{C}$ was still sufficiently available to the denitrifiers. These data indicated that the denitrification wall was still effective after 14 years.

To predict denitrification wall longevity, a first-order decay curve was fitted to the total $\mathrm{C}$ data through time $\left(\mathrm{R}^{2}=0.92 ; \mathrm{p}<0.05\right)$. The decay curve was used to predict the time until total $\mathrm{C}$ reached $0.1 \%$, although it is unclear at what $\% \mathrm{C}$ denitrification will become $\mathrm{C}$ limited. Using this decay curve, it was estimated that $\mathrm{C}$ in the wall would not be depleted for 66 years, although it is possible that $\mathrm{C}$ will become limiting to denitrifiers before that time. This long-term study suggested that denitrification walls are cost-effective solutions to removing $\mathrm{NO}_{3}{ }^{-}$from groundwater as they can be effective for a number of years without any maintenance. 


\section{Acknowledgements}

First and foremost I would like to thank my supervisor, Dr. Louis Schipper, for all of his advice, help and support throughout my thesis. I would also like to think Dr. Denise Bruesewitz for her statistics help, reading drafts of my thesis, and also for all of her support when I first arrived in New Zealand. I also express my appreciation to Dr. Susanna Rutledge and Stewart Cameron for reading a draft of my main chapter and providing valuable input.

I would like to thank Chris McKinnon for his many hours spent helping me in the field. I would also like to thank Annette Rodgers, Louise Fisk, and Craig Hosking for filling in as my field helper when needed. Jacinta Parenzee was a huge help in the lab and I thank her for introducing me to the lab and helping me learn the various methods I needed to perform. A special thanks to Yvonne Tay for taking time away from her own research to teach me how to use the FIA to analyze my water samples. A thank you must be extended to Anjana Rajendram and Alex McGill for running analyses on my soil samples. I acknowledge Ray Littler for assistance in statistical analysis.

To Fulbright New Zealand, thank you for funding my stay in New Zealand; this has been a truly worthwhile experience and I have learned much about myself as well as New Zealand culture and academia. I acknowledge Landcare Research Ltd. contract C09X0705 for providing support for this research.

Finally, I would like to thank my family, especially my parents, for their support in my moving to New Zealand. I would like to thank my friends, especially Sam, for keeping me sane and providing occasional welcome distractions. 
Table of Contents

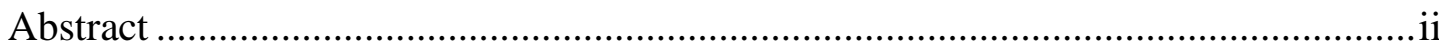

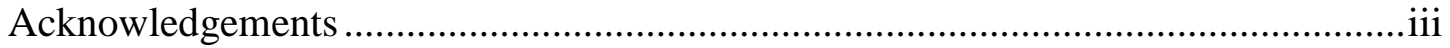

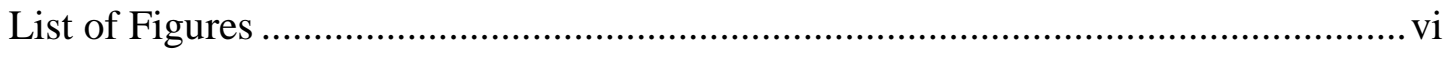

List of Tables.....................................................................................................

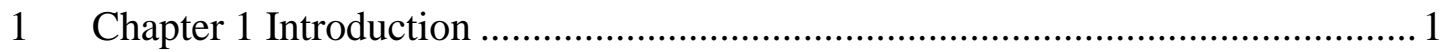

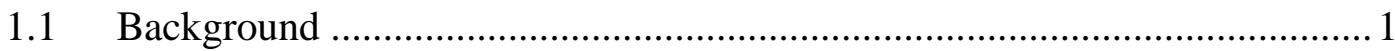



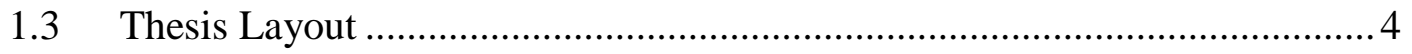



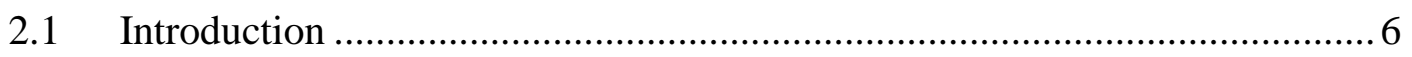

2.2 Structure of Literature Review ........................................................... 6

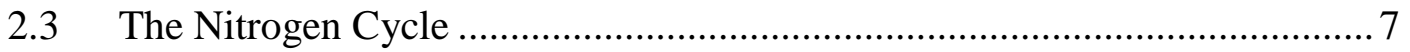

2.4 Nitrogen as an Environmental Contaminant ........................................... 8

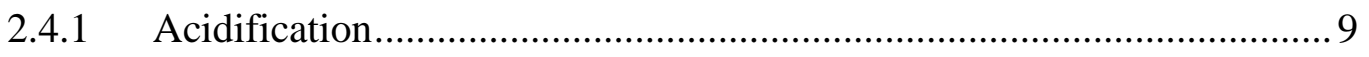



2.4.3 Health Effects........................................................................... 10



2.4.5 Nitrogen in Groundwater ............................................................ 11

2.5 Nitrate Management in New Zealand .................................................. 12

2.6 Methods of Removing Nitrate through Denitrification ............................. 14

2.6.1 Land Application..................................................................... 15

2.6.1.1 Principles of Land Application ................................................ 15

2.6.1.2 Land Based Effluent Treatment Systems in New Zealand ............ 16



2.6.3 Water Table Management ................................................................ 20

2.6.4 Agricultural Ditches and Streams ................................................... 21

2.6.5 Addition of Simple Carbon Sources to Groundwater .........................2 23

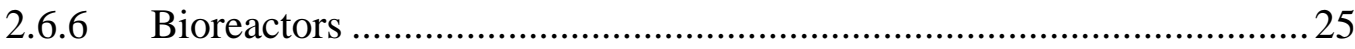

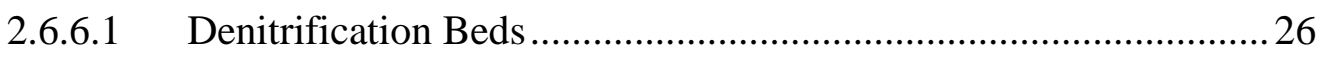

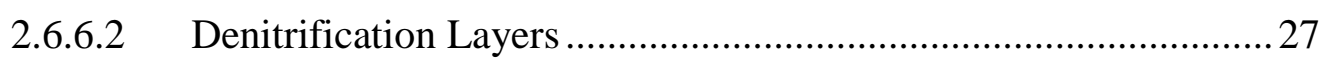

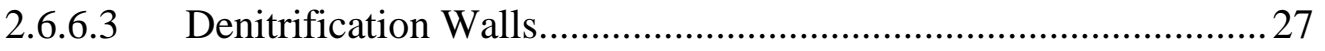


3 Chapter 3 Long Term Nitrate Removal in a Denitrification Wall ......................34

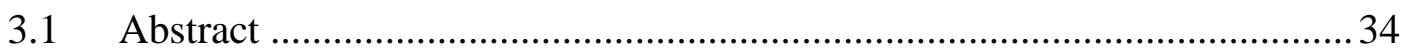

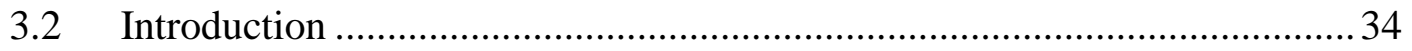

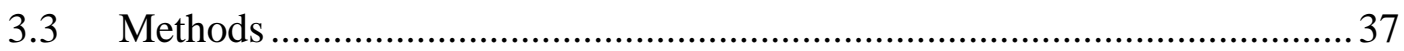

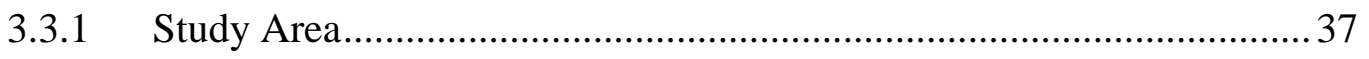

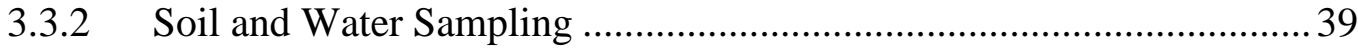

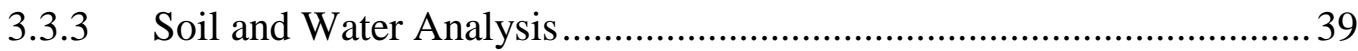

3.3.4 Loss of Carbon over Time............................................................. 41

3.3.5 Statistical Analysis ..................................................................... 41

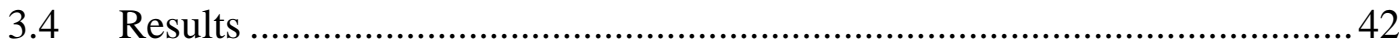

3.4.1 Nitrate Removal and Biochemistry ................................................. 42

3.4.2 Depth Profiles ....................................................................... 47

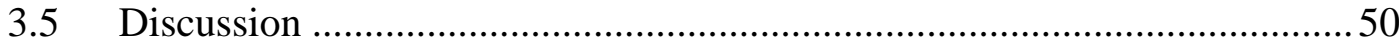

3.5.1 Nitrate Removal and Biochemistry .................................................50

3.5.2 Longevity of Denitrification Walls ................................................. 51

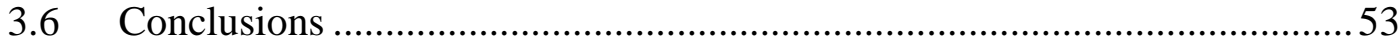



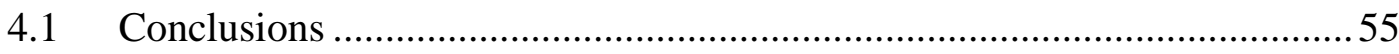

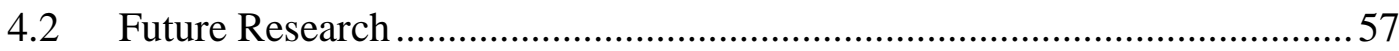

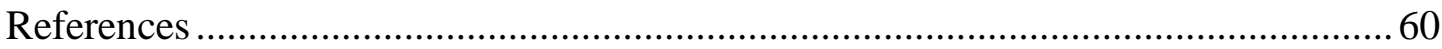



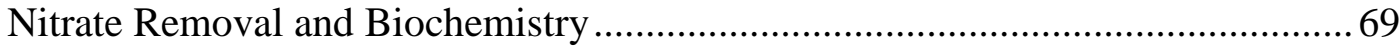

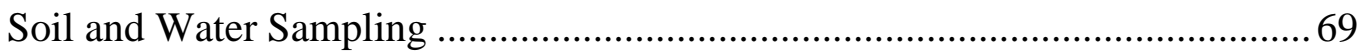

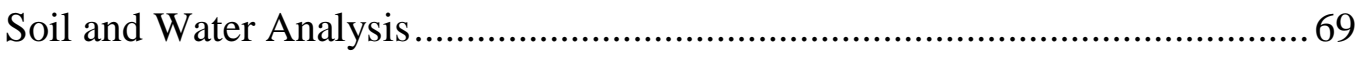

Loss of Carbon over Time.................................................................... 72

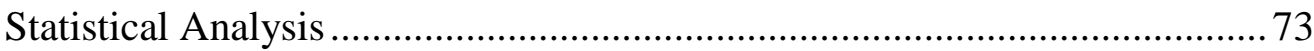

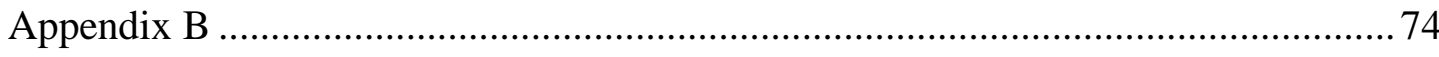






\section{List of Figures}

Figure 2.1: A simplified version of the Nitrogen Cycle.

Figure 2.2: A simple diagram demonstrating a two-stage channel; a two-stage channel is an agricultural ditch designed to maintain physical stability while preserving function in terms of removing water quickly from agricultural fields. 23

Figure 2.3: A diagram of a denitrification wall, a permeable reactive barrier designed to remove nitrate $\left(\mathrm{NO}_{3}{ }^{-}\right)$from groundwater. 28

Figure 3.1 A. Photo of the New Zealand denitrification wall taken from the side. The set of wells to the left are the upslope wells, the wells in the middle are within the wall, and the wells to the right are downslope of the wall. B. A diagram showing the layout of the groundwater wells in association with the denitrification wall. .38 Figure 3.2 Nitrate concentrations (averaged through time) upslope, within, and downslope of the wall over a two month period in $2010(\mathrm{n}=4$ and data are presented +/- 1 SE). Samples were taken on 20 July, 18 August, 23 August, and 30 August. The wells are arranged along the length of the wall at approximately $2 \mathrm{~m}$ intervals with the first and last well approximately $1 \mathrm{~m}$ from the edge of the denitrification wall.

Figure 3.3 Nitrate input to the denitrification wall and nitrate within the wall since installation in $1996(\mathrm{n}=10$ and data presented are $+/-1 \mathrm{SE})$. Note that there was a period of 9 years where no samples were taken and that the time scale is 30 days after the break in the $\mathrm{x}$-axis.

Figure 3.4 Denitrifying enzyme activity (DEA) rates over time in the denitrification wall since installation in 1996. Note that there was a period of 9 years where no samples were taken and that the time scale is 30 days after the break in the $\mathrm{x}$-axis. DEA data are presented $\log$-transformed $(n=6$ and data presented are $+/-1 \mathrm{SE}) \ldots . .45$ Figure 3.5 Total carbon, available carbon, and microbial biomass carbon over time in the denitrification wall since installation in $1996(\mathrm{n}=6$ and data presented are $+/-1$ $\mathrm{SE})$. Note that there was a period of 9 years where no samples were taken and that the time scale is 30 days after the break in the $\mathrm{x}$-axis. 46 
Figure 3.6 Increases in denitrifying enzyme activity (DEA) compared with increases in available $\mathrm{C}$ measured under aerobic conditions. Samples were taken at $0.5 \mathrm{~m}$ and 1

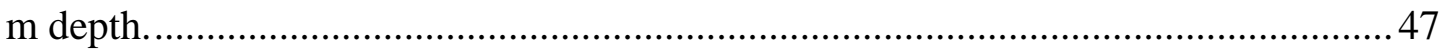

Figure 3.7 Depth profile sampling taken on 23 August 2010 for total carbon, available carbon, microbial biomass carbon, and denitrifying enzyme activity within the denitrification wall $(\mathrm{n}=6$ and data presented are $+/-1 \mathrm{SE})$. 


\section{List of Tables}

Table 2-1: The efficiency of various simple $\mathrm{C}$ substrates that have been tested in

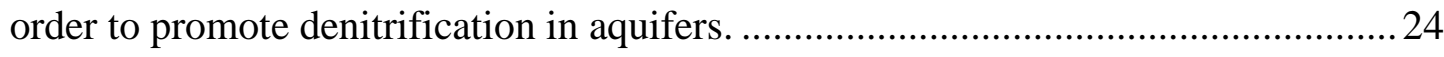

Table 3-1 Depth to water table and soil temperature on dates of sampling. Depth to water table is an average of 10 measurements. *n.m. means not measured. . 39

Table 3-2 ANOVA output for the denitrifying enzyme activity (DEA) amendment experiment. Potential denitrification rates were measured on soil samples that were amended with (i) nitrate $(\mathrm{N})$ only, (ii) carbon $(\mathrm{C})$ only, or (iii) both $\mathrm{N}+\mathrm{C}$. Values with $\mathrm{p}<0.05$ are considered significant. $\mathrm{N}+\mathrm{C}$ is the interaction component to determine co-limitation. 


\section{Chapter 1 Introduction}

\subsection{Background}

Nitrogen $(\mathrm{N})$ is one of the five major elements necessary for life, and it is the most abundant of those elements both in the atmosphere and on earth (Galloway et al., 2003). However, more than $99 \%$ of $\mathrm{N}$ on earth is dinitrogen gas $\left(\mathrm{N}_{2}\right)$, which is unavailable to more than $99 \%$ of organisms (Galloway et al., 2003). The two N atoms in $\mathrm{N}_{2}$ gas are held together by a triple bond, which is extremely energy intensive to break. $\mathrm{N}$ only becomes available through fixation by microbes in symbiosis with specific plants or abioticaly with lightening (Galloway et al., 2003). $\mathrm{N}$ fixation is the transformation of $\mathrm{N}_{2}$ to the biologically available form of ammonium $\left(\mathrm{NH}_{4}^{+}\right)$(Vitousek et al., 1997). As a result of short supply, biologically available $\mathrm{N}$ (referred to as reactive $\mathrm{N}$ ) often controls primary production (Gruber and Galloway, 2008). This paradox has led to increased cultivation of $\mathrm{N}$-fixing plants and development of the Haber-Bosch process in 1910, which converts $\mathrm{N}_{2}$ to ammonia $\left(\mathrm{NH}_{3}\right)$, to be used as a fertilizer (Galloway et al., 2003).

Prior to anthropogenic $\mathrm{N}$ fixation, the rate of $\mathrm{N}$ produced by biological $\mathrm{N}$ fixation was roughly in balance with the amount of $\mathrm{N}$ removed from the ecosystem through denitrification (Galloway et al., 2003). Denitrification is an anaerobic process of microbial respiration that converts nitrate $\left(\mathrm{NO}_{3}{ }^{-}\right)$to $\mathrm{N}_{2}$ gas (Galloway, 1998). Consequently, there was little redistribution or accumulation of $\mathrm{N}$ in the environment (Galloway, 1998). The global population boom over the past two centuries has led to an increase in fossil fuel consumption as well as food production supported by $\mathrm{N}$ fertilizer and increased $\mathrm{N}$ fixation, all of which have led to ever increasing amounts of reactive $\mathrm{N}$ added to the environment (Vitousek et al., 1996). In 1970, anthropogenic $\mathrm{N}$ inputs accounted for $70 \mathrm{Tg} \mathrm{N}$ year ${ }^{-1}$, and by the mid-1990s, that number had doubled to $140 \mathrm{Tg} \mathrm{N}$ year $^{-1}$ (Galloway, 1998). This trend of increasing anthropogenic $\mathrm{N}$ inputs must increase as long as population increases, because there is no alternative to reactive $\mathrm{N}$ in food production unless agricultural $\mathrm{N}$-use efficiency is increased (Galloway, 1998). 
In addition to increasing $\mathrm{N}$ fixation, humans have also mobilized large pools of $\mathrm{N}$ through biomass burning, land clearing, and drainage of wetlands (Vitousek et al., 1996). This is particularly worrisome because the rate that humans are adding $\mathrm{N}$ is faster than the removal through denitrification within many ecosystems, leading to the movement of $\mathrm{N}$ to downstream receiving environments such as lakes or estuaries (Galloway et al., 2003). N is so mobile because it has many different species along the redox gradient $(-3$ to +5$)$ and therefore readily transformed (Robertson and Vitousek, 2009). Of particular concern is that $\mathrm{N}$ transformations often lead to multiple effects, referred to as the $\mathrm{N}$ cascade (e.g. reactive $\mathrm{N}$ can lead to eutrophication in the water, but can subsequently be released as the greenhouse gas nitrous oxide $\left(\mathrm{N}_{2} \mathrm{O}\right)$ as a byproduct of denitrification) (Galloway et al., 2003).

It is important to remediate $\mathrm{N}$ at the source in order to avoid adverse impacts of the $\mathrm{N}$ cascade. Promoting denitrification is one way to remediate N. Denitrification is a microbial respiration process, performed by facultative denitrifying microbes, that uses $\mathrm{NO}_{3}{ }^{-}$rather than oxygen $\left(\mathrm{O}_{2}\right)$ as an electron acceptor (Tiedje, 1988; Seitzinger et al., 2006). To promote denitrification, there needs to be an absence of $\mathrm{O}_{2}, \mathrm{NO}_{3}{ }^{-}$ available as an electron acceptor, and labile carbon (C) to act as an energy source for the denitrifying microbes (Soares, 2000). Denitrification is a permanent removal of $\mathrm{N}$ from ecosystems, but the increased movement of $\mathrm{N}$ away from the site of input typically results in denitrification occurring distally from the initial input (Galloway et al., 2003). This spatial disconnect between input and output of $\mathrm{N}$ causes problems in the intermediate ecosystems that $\mathrm{N}$ moves through, leading to the need for active management at the source of $\mathrm{N}$ input in order to denitrify $\mathrm{N}$ before it moves downstream.

One technique that has been studied to treat excess $\mathrm{NO}_{3}{ }^{-}$by enhancing denitrification at its source is a denitrification wall (Robertson and Cherry, 1995; Schipper and Vojvodic-Vukovic, 1998; Jaynes et al., 2008). Denitrification walls are permeable reactive barriers (a solid $\mathrm{C}$ source mixed with soil) installed within the groundwater table. As groundwater flows through the wall, the $\mathrm{C}$ acts as an energy source for 
denitrifiers to transform $\mathrm{NO}_{3}{ }^{-}$in the groundwater to $\mathrm{N}_{2}$ gas. Denitrification walls are low-cost and low-maintenance, but a key factor in terms of wide spread adoption is how long they will be effective at $\mathrm{NO}_{3}{ }^{-}$removal. They have been shown to continue to remove $\mathrm{NO}_{3}{ }^{-}$for 7 years (Robertson et al., 2000; Schipper and Vojvodic-Vukovic, 2005), 9 years (Moorman et al., 2010), and in the only decadal study, up to 15 years (Robertson et al., 2008). Robertson et al. (2008) took cores from the denitrification wall and then ran $\mathrm{NO}_{3}{ }^{-}$through them in a lab; a full field sampling was not undertaken. More information is needed on long-term performance in wide variety of settings.

\subsection{Objectives}

The overall aim of this study was to further understanding of the ability and limitations of denitrification walls in the removal of $\mathrm{NO}_{3}{ }^{-}$from groundwater.

The specific objectives were:

- To determine whether a denitrification wall installed at Cambridge, New Zealand, continued to support denitrification and $\mathrm{NO}_{3}{ }^{-}$removal 14 years after installation.

- To determine if $\mathrm{C}$ substrate and denitrification rates vary throughout the vertical soil profile within the denitrification wall.

This study takes advantage of a denitrification wall constructed in Cambridge, New Zealand in 1996. Since the last study on this wall (Schipper et al., 2005), available C will likely have decreased as anaerobic respiration will have consumed some of the sawdust. However, the decrease of available $\mathrm{C}$ from sawdust has shown to be a slow process (Schipper and Vojvodic-Vukovic, 2001), and the 2005 study found the microbial biomass $\mathrm{C}$ to be stable throughout the first seven years since installation (Schipper et al., 2005). Therefore, I expected to find a sufficient amount of $\mathrm{C}$ and denitrifying microbes present to continue to support denitrification. Alternatively, it is possible that the water table had dropped below the wall for a sufficient amount of time to allow aerobic respiration, which would greatly increase sawdust decomposition (Schipper and Vojvodic-Vukovic, 2001). Although previous work 
showed a substantial decline in denitrifying enzyme activity (DEA) after $5-7$ years in this wall, (Schipper and Vojvodic-Vukovic, 2001; Schipper et al., 2005), they also found that denitrification rates in the wall remained high enough to support significant $\mathrm{NO}_{3}{ }^{-}$removal.

Overall, I hypothesized that the denitrification wall will support denitrification and $\mathrm{NO}_{3}{ }^{-}$removal 14 years after installation.

Moorman et al. (2010) found that $\mathrm{C}$ at depth decayed slower than $\mathrm{C}$ closer to the soil surface in a denitrification wall in Iowa, USA. I hypothesize that a similar result will be found in the New Zealand denitrification wall. Approximately the first $50 \mathrm{~cm}$ in the soil profile can become quite dry and aerobic during summer months which would increase sawdust decomposition (Schipper and Vojvodic-Vukovic, 2001), while deeper soils appear to retain some moisture. I would expect to find more C below $50 \mathrm{~cm}$ in the denitrification wall and consequently, higher denitrification rates.

\subsection{Thesis Layout}

Chapter 2 reviews literature on the effects of $\mathrm{N}$ in the environment as well as methods for removal, with a specific focus on denitrifying bioreactors. The review will be centred on global as well as New Zealand systems.

Chapter 3 is the main component of the thesis and presents the data and discussion on the long-term effectiveness of a denitrification wall that was constructed 14 years ago. Chapter 3 has been written as a paper and was submitted to Agriculture, Ecosystems \& Environment. It was accepted with moderate revisions on 20 January 2010. Consequently, some repetition of introductory and literature material is necessary.

Chapter 4 presents a summary and conclusions for the thesis as well as recommendations for further research. 
Appendix A provides detailed methods for all sampling and analyses undertaken for this thesis.

Appendix B provides the data I collected and used in this thesis.

Appendix C presents the reviewer's comments and my responses for the manuscript (Chapter 3) I submitted to Agriculture, Ecosystems \& Environment. 


\section{Chapter 2 Literature Review}

\subsection{Introduction}

Nitrogen $(\mathrm{N})$ is central to biology; it is the primary constituent of nucleotides and proteins. However, most $\mathrm{N}$ is biologically unavailable in the form of $\mathrm{N}$ gas $\left(\mathrm{N}_{2}\right)$, therefore limiting plant production and affecting the structure and function of both terrestrial and aquatic ecosystems (Robertson and Vitousek, 2009). N is important for agricultural systems as the addition of $\mathrm{N}$ increases crop yields and displaces $\mathrm{N}$ fixing plants (Robertson and Vitousek, 2009). The reliance on anthropogenic $\mathrm{N}$ inputs to agricultural systems has greatly increased the amount of $\mathrm{N}$ being introduced to downstream ecosystems; this has caused dramatic changes to the $\mathrm{N}$ cycle leading to various environmental and health risks (Galloway et al., 2003). Over the past few decades, more research has been undertaken to develop methods for removing excess $\mathrm{N}$ from ecosystems. Among the most promising technologies are those enhancing denitrification, as the conversion to $\mathrm{N}_{2}$ gas is a permanent removal of $\mathrm{N}$.

\subsection{Structure of Literature Review}

This literature review explores the topic $\mathrm{N}$ in the environment and is broken into two main sections: (i) $\mathrm{N}$ cycling and (ii) approaches for removing reactive $\mathrm{N}$ (all biologically and chemically active $\mathrm{N}$ compounds). The first section is devoted to $\mathrm{N}$ cycling and the effects of excess $\mathrm{N}$ on the environment; it will discuss the potential ways $\mathrm{N}$ naturally enters and exits ecosystems as well as transformations within ecosystems. It is followed by a review of anthropogenic changes to the $\mathrm{N}$ cycle and how these changes have impacted the environment and human health. The second section discusses methods of removing excess reactive $\mathrm{N}$ from ecosystems via denitrification, with a focus on agricultural systems. It will discuss the role of denitrification in permanent $\mathrm{N}$ removal, the environmental factors that often limit denitrification, and the different technologies that have been developed on the premise of enhancing denitrification. The section ends with a segment on denitrifying bioreactors, a low-cost and low-maintenance technology for promoting denitrification in shallow ground water. 


\subsection{The Nitrogen Cycle}

Nitrogen is the most abundant element in the atmosphere and it is also ubiquitous in terrestrial and aquatic ecosystems. Understanding how $\mathrm{N}$ cycles through the atmosphere as well as aquatic and terrestrial ecosystems is important to understand in terms of environmental quality. For this reason, the $\mathrm{N}$ cycle (Figure 2.1) has been studied by numerous researchers.

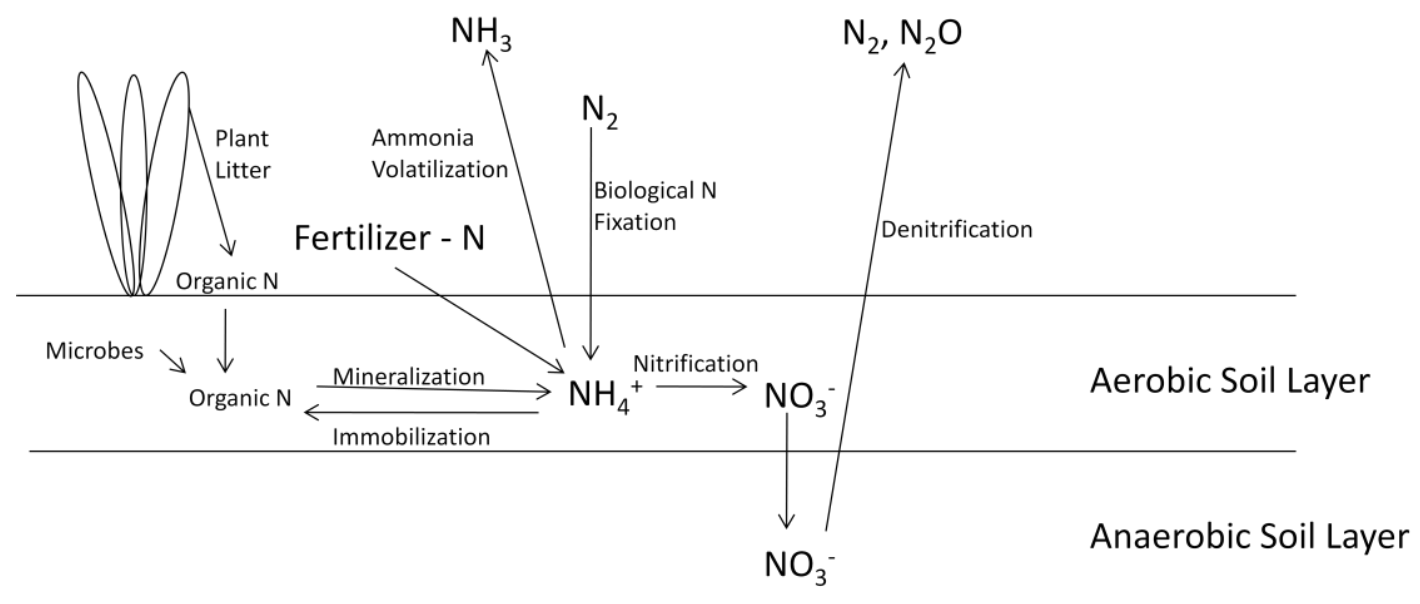

Figure 2.1: A simplified version of the Nitrogen Cycle.

Nitrogen comprises $78 \%$ of Earth's atmosphere, but it is mostly in the biologically unavailable form of $\mathrm{N}_{2}$ gas (Smil, 1997). In order to be utilized by plants and other organisms, $\mathrm{N}_{2}$ must be transformed into a bio-available form. This occurs through the process of $\mathrm{N}$ fixation where $\mathrm{N}$-fixing microbes transform $\mathrm{N}_{2}$ to ammonium $\left(\mathrm{NH}_{4}{ }^{+}\right)$which is then readily available for use by plants or bacteria (Vitousek et al., 1997). The mineral forms of $\mathrm{N}$ (collectively known as dissolved organic N (DIN): $\mathrm{NH}_{4}^{+}, \mathrm{NO}_{3}{ }^{-}, \mathrm{NO}_{2}{ }^{-}$) also becomes available to organisms when organic $\mathrm{N}$ in living tissues degrade (Myrold, 2004). $\mathrm{NH}_{4}{ }^{+}$can be released to the atmosphere as ammonia $\left(\mathrm{NH}_{3}\right)$ through abiotic ammonia volatilization (Vitousek et al., 1997), or oxidized to nitrite $\left(\mathrm{NO}_{2}{ }^{-}\right)$and nitrate $\left(\mathrm{NO}_{3}{ }^{-}\right)$through the aerobic process of nitrification (Falkowski, 1997). $\mathrm{NO}_{3}{ }^{-}$can be taken up by plants or microbes, accumulate in the ecosystem, or leach from the system to be subsequently transported to a downstream system (Falkowski, 1997). $\mathrm{NO}_{3}{ }^{-}$can also be transformed through dissimilatory $\mathrm{NO}_{3}{ }^{-}$ 
reduction to ammonium (DNRA), the complete reduction of $\mathrm{NO}_{3}{ }^{-}$to $\mathrm{NH}_{4}{ }^{+}$under anaerobic conditions (Myrold, 2004). Alternative pathways for permanent $\mathrm{NO}_{3}{ }^{-}$ removal are denitrification, the microbial conversion to $\mathrm{N}$ gases, and anaerobic $\mathrm{NH}_{4}{ }^{+}$ oxidation (anammox), by which $\mathrm{NH}_{4}{ }^{+}$is combined with $\mathrm{NO}_{2}{ }^{-}$to produce $\mathrm{N}_{2}$ (Burgin and Hamilton, 2007).

Denitrification is a pathway of permanent removal of reactive $\mathrm{N}$ from terrestrial and aquatic systems and therefore this microbial process is extremely important in terms of protection of environmental quality. Denitrification is the dissimilatory reduction of $\mathrm{NO}_{3}{ }^{-}$to $\mathrm{N}_{2}$ by bacteria (Seitzinger et al., 2006). Denitrification is a respiratory process, where the bacteria use $\mathrm{NO}_{3}{ }^{-}$as a terminal electron acceptor; these bacteria are facultative anaerobes which will also use oxygen $\left(\mathrm{O}_{2}\right)$ when it is present (Soares, 2000). Denitrification can be incomplete resulting in $\mathrm{N}_{2} \mathrm{O}$ production, a potent greenhouse gas (Galloway et al., 2003). The process can be summarized as follows:

$\mathrm{NO}_{3}{ }^{-} \rightarrow \mathrm{NO}_{2}{ }^{-} \rightarrow \mathrm{NO} \rightarrow \mathrm{N}_{2} \mathrm{O} \rightarrow \mathrm{N}_{2}$

\subsection{Nitrogen as an Environmental Contaminant}

Excess $\mathrm{N}$ in the environment has led to four major environmental problems: acidification of freshwater bodies; eutrophication and associated hypoxic zones; adverse health effects for aquatic organisms as well as humans; and $\mathrm{N}_{2} \mathrm{O}$ production (Camargo and Alonso, 2006). $\mathrm{NO}_{3}{ }^{-}$concentrations in the environment (specifically groundwater) have increased throughout the world in recent decades due to the use of synthetic-N fertilizers and cultivation of $\mathrm{N}$-fixing crops (Rupert, 2008; Vitousek et al., 1997). Elevated amounts of $\mathrm{N}$ in the environment lead to higher concentrations of reactive $\mathrm{N}$ which can then cascade through multiple ecosystems (Galloway et al., 2003). Galloway et al. (2003) describes an example of the $\mathrm{N}$ cascade: reactive $\mathrm{N}$ (as $\mathrm{NH}_{3}$ ) is created industrially and then applied to agricultural fields as fertilizer. $\mathrm{NH}_{3}$ can be transformed to $\mathrm{NO}_{3}{ }^{-}$through nitrification which then becomes mobile and causes eutrophication or hypoxia in downstream ecosystems. Agricultural practices require a high energy input and fossil fuel combustion releases $\mathrm{N}$ oxides $\left(\mathrm{NO}_{\mathrm{x}}\right)$ into 
the atmosphere. $\mathrm{NO}_{\mathrm{x}}$ can combine with volatile organic carbon $(\mathrm{C})$ compounds in the atmosphere leading to higher concentrations of ozone and other photochemical oxidants. $\mathrm{NO}_{x}$ can then be converted to $\mathrm{HNO}_{3}$ (nitric acid) in the atmosphere and then either deposited on land or surface waters leading to acidification of water bodies. There are extensive reviews on this subject (e.g. Rabalais, 2002; Galloway et al., 2003; Camargo and Alonso, 2006; Robertson and Vitousek, 2009) and the following is a synopsis.

\subsubsection{Acidification}

Nitrogen dioxide $\left(\mathrm{NO}_{2}\right)$ and nitrogen oxide $(\mathrm{NO})$ are both known acidifiers of freshwater bodies (Camargo and Alonso, 2006). These gases have been released into the atmosphere at increasing rates over the last few decades, and when they reach the atmosphere, they transform into $\mathrm{HNO}_{3}$ (Camargo and Alonso, 2006). The $\mathrm{HNO}_{3}$ can then enter water bodies via wet deposition. Since freshwater bodies have limited acid-neutralizing abilities (Rabalais, 2002), the increase in hydrogen ion $\left(\mathrm{H}^{+}\right)$ concentration due to $\mathrm{HNO}_{3}$ can significantly lower the $\mathrm{pH}$ of the water. Certain fish are acid-sensitive and therefore direct mortality ensues after acidification (Camargo and Alonso, 2006). Additionally, as $\mathrm{pH}$ decreases, aluminium (Al) concentrations increase, causing direct toxicity to fish (Rabalais, 2002). A lower $\mathrm{pH}$ can also lead to enhanced heavy metal mobility, inhibit microbial processes, reduce net algal productivity, and slow development of fish and amphibian embryos (Camargo and Alonso, 2006).

\subsubsection{Eutrophication}

Since many water bodies are $\mathrm{N}$ limited, eutrophication caused by $\mathrm{N}$ is one of the most common threats to water bodies globally (Spalding and Exner, 1993; Carpenter et al., 1998; Galloway et al., 2003). Human activities have caused recent and widespread eutrophication in New Zealand water bodies due to increased agricultural land use change and intensification (Hamilton, 2005; Edgar, 2009). Eutrophication causes increased algal growth, $\mathrm{O}_{2}$ shortages (hypoxia), and fish kills in surface waters (Carpenter et al., 1998). Oxygen depletion due to eutrophication is most dramatically manifested in the hypoxic zones of the Gulf of Mexico, Chesapeake 
Bay, and the Baltic and Black Seas (Rabalais, 2002). These hypoxic zones have been coined "dead zones" due to the extensive kills of fishes and invertebrates. Other symptoms of eutrophication include formation of toxic, reduced chemical compounds and loss of algal diversity (Camargo and Alonso, 2006). Reduction of light penetration due to turbidity is another effect of eutrophication, which limits submerged aquatic vegetation (SAV) growth (Rabalais, 2002). Lower SAV leads to less refuge, feeding, and nursery areas for fish. Eutrophication also leads to a loss of diversity both in benthic organisms (due to a lack of light penetration) and among planktonic organisms (due to stimulated algal blooms) (Vitousek et al., 1996).

\subsubsection{Health Effects}

The third major environmental problem due to increased $\mathrm{N}$ availability is adverse health effects for aquatic organisms. $\mathrm{NH}_{4}{ }^{+}, \mathrm{NH}_{3}, \mathrm{NO}_{2}{ }^{-}$, and $\mathrm{NO}_{3}{ }^{-}$are four inorganic forms of $\mathrm{N}$ that can be toxic to organisms. As $\mathrm{pH}$ increases, the concentration of $\mathrm{NH}_{3}$ also increases (Randall and Tsui, 2002). $\mathrm{NH}_{3}$ is toxic to the bacteria responsible for nitrification, Nitrosomonas and Nitrobacter, and therefore inhibits the transformation of $\mathrm{NH}_{4}{ }^{+}$to $\mathrm{NO}_{3}{ }^{-}$(Camargo and Alonso, 2006). Reduced nitrification results in $\mathrm{NH}_{4}{ }^{+}$ and $\mathrm{NH}_{3}$ in the water body. The toxicity of $\mathrm{NH}_{3}$ causes damage to fish gills, mussels, and other macroinvertebrates, suppression of the Krebs cycle and suppression of the immune system (Camargo and Alonso, 2006).

As with $\mathrm{NH}_{3}, \mathrm{NO}_{2}{ }^{-}$also increases with increasing $\mathrm{pH}$ (Camargo and Alonso, 2006). The main problem with increased concentrations of $\mathrm{NO}_{2}{ }^{-}$is the conversion of $\mathrm{O}_{2}{ }^{-}$ carrying pigments in blood to forms that are not able to carry $\mathrm{O}_{2}$, therefore leading to hypoxia or even death in humans (Jensen, 2003). $\mathrm{NO}_{3}{ }^{-}$has the same effect and high levels of $\mathrm{NO}_{3}{ }^{-}$in drinking water have been implicated in "blue baby syndrome", or methaemoglobinemia, where the $\mathrm{O}_{2}$ carrying capability of haemoglobin is blocked (Camargo and Alonso, 2006), although Powlson et al. (2008) presents evidence that $\mathrm{NO}_{3}{ }^{-}$may not cause methaemoglobinemia in humans. There is limited evidence that increased $\mathrm{NO}_{3}{ }^{-}$concentrations may also cause cancers in the digestive tract, coronary heart disease, contribute to the risks of non-Hodgkin's lymphoma, and respiratory tract infections (Camargo and Alonso, 2006). 


\subsection{4 $\mathrm{N}_{2} \mathrm{O}$ Emission}

$\mathrm{N}_{2} \mathrm{O}$ is produced during both nitrification and denitrification. Under aerobic conditions $\mathrm{N}_{2} \mathrm{O}$ production accounts for less than $1 \%$ of $\mathrm{N}$ transformed during nitrification, while the amount produced during denitrification is variable (Myrold, 2004). The addition of $\mathrm{N}$ to agricultural land has led to increasing $\mathrm{N}_{2} \mathrm{O}$ emissions as rates of both nitrification and denitrification increase with additional $\mathrm{N}$ inputs (Galloway et al., 2003). For thousands of years, $\mathrm{N}_{2} \mathrm{O}$ concentrations in the atmosphere had been stable at $270 \mathrm{ppbv}$ (parts per billion by volume), but have increased to $320 \mathrm{ppbv}$ over the last 200 years, primarily due to altered agricultural practices (Robertson and Vitousek, 2009). $\mathrm{N}_{2} \mathrm{O}$ is accumulating in the atmosphere at about $0.3 \%$ per year (Schlesinger, 2009). $\mathrm{N}_{2} \mathrm{O}$ is a potent greenhouse gas in the troposphere, where is has a residence time of 100 years, and when present in the stratosphere decreases the concentration of ozone (Galloway et al., 2003). As a greenhouse gas, $\mathrm{N}_{2} \mathrm{O}$ absorbs infrared radiation in spectral windows that other gases do not cover (Vikousek et al., 1997). As a result, accumulation of $\mathrm{N}_{2} \mathrm{O}$ in the atmosphere can greatly influence climate change as it is 300 times more potent as a greenhouse gas than $\mathrm{CO}_{2}$ (Robertson and Vitousek, 2009).

\subsubsection{Nitrogen in Groundwater}

In the United States, more than $20 \%$ of rural wells have $\mathrm{NO}_{3}{ }^{-}$concentrations above the drinking water limit of $10 \mathrm{mg} \mathrm{N} \mathrm{L}^{-1}$ (Rupert, 2008). Because this problem also occurs in many other nations, $\mathrm{NO}_{3}{ }^{-}$is considered the most widespread groundwater contaminant in the world (Spalding and Exner, 1993). This issue is important in New Zealand where $50 \%$ of community water supplies and many domestic wells in rural communities use groundwater as the sole or partial drinking water source (Close et al., 2001). The transport of $\mathrm{N}$ to groundwater generally occurs through leaching from agricultural systems, although in some nations, human waste can also be an important source (Galloway et al., 2003). As fertilizer use expands, N leaching will increase leading to larger amounts of $\mathrm{N}$ being transported through fluvial systems away from the point of application (Schlesinger, 2009). The distribution of $\mathrm{NO}_{3}{ }^{-}$in groundwater is controlled by hydrology, dissolved $\mathrm{O}_{2}$ concentrations, and electron donor availability (Spalding and Exner, 1993). While the best approach to decrease 
groundwater contamination is preventing $\mathrm{NO}_{3}{ }^{-}$from reaching the groundwater in the first place by changing $\mathrm{N}$ fertilizer application practices or enhancing $\mathrm{N}$ uptake in the agricultural system, groundwater $\mathrm{NO}_{3}{ }^{-}$pollution is on the rise in developing countries and will continue to increase as large-scale fertilization increases (Soares, 2000). It is critical to treat $\mathrm{N}$ contamination near the source before it moves through downstream ecosystems and causes more environmental problems. Because of this, it is paramount that low-cost, low-maintenance solutions for removing $\mathrm{N}$ from groundwater continue to be developed.

\subsection{Nitrate Management in New Zealand}

In general, there is much to be determined on the fate of applied $\mathrm{N}$ to landscapes, except that most of the $\mathrm{N}$ is transported from the point of application through various processes (Schlesinger, 2009). Globally, approximately $10 \%$ of $\mathrm{N}$ added to agricultural fields is retained in food, while the rest is released to the environment through leaching, denitrification, and ammonia volatilization (Schlesinger, 2009).

Ecosystems that are especially susceptible to suffering damage from $\mathrm{N}$ inputs are systems that are $\mathrm{N}$-limited; addition of a limiting nutrient to an ecosystem will rapidly increase production ultimately leading to eutrophication if increasing amounts of the limiting nutrient are available (Koerselman and Meuleman, 1996). New Zealand is a low $\mathrm{N}$ environment as evidenced by low $\mathrm{N}$ concentrations in mountain streams (Stenzel and Herrmann, 1990) as well as rainwater (Nichol et al., 1997). The ambient concentration of $\mathrm{N}$ in New Zealand aquifers has not been studied in detail, but the high flow rates in aquifers and the high rates of rainfall in many parts of the country suggest that ambient $\mathrm{N}$ levels are low, less than $1 \mathrm{~g} \mathrm{~N} \mathrm{~m}^{-3}$ (Close et al., 2001). The low concentrations of $\mathrm{N}$ suggest that the environment is $\mathrm{N}$ limited and especially susceptible to anthropogenic $\mathrm{N}$ inputs. In fact, increasing agricultural development has been linked to the degradation of New Zealand's lakes, primarily due to $\mathrm{N}$ fertilizer and animal waste (Hamilton, 2005; Edgar, 2009). New Zealand's low N environment tends to promote $\mathrm{N}$-fixing legumes, but in areas of high application of $\mathrm{N}$ fertilizer, grasses tend to dominate (Ledgard, 2001). Grazed legume pastures, which have less $\mathrm{N}$ in the soil than agricultural systems that use fertilizer, have the potential 
to sustain moderate to high levels of productivity in the long-term, but production still tends to be limited by $\mathrm{N}$ availability (Ledgard, 2001). Because of this, some New Zealand dairy practices have become increasingly reliant on $\mathrm{N}$ fertilizer inputs.

In New Zealand, $\mathrm{NO}_{3}{ }^{-}$contamination in groundwater is associated with intensive pasture grazing and fertilization of cropland (Close et al., 2001). As of 2002, New Zealand had a total of 13,600 dairy farms and agricultural land use is continuing to increase (Wang et al., 2004). New Zealand dairy grazing generates large amounts of effluent, which contain $\mathrm{N}$ as well as other nutrients and heavy metals (Wang et al., 2004). On New Zealand farms, $\mathrm{N}$ fertilizer use has intensified over recent years from $50 \mathrm{Gg}$ in 1989 to $342 \mathrm{Gg}$ in 2003 in order to increase production from a fixed land area (Parfitt et al., 2006). Not only is land use intensification occurring in terms of fertilizer inputs, but also in terms of energy and water for irrigation (PCE, 2004).

Parfitt et al. (2006) estimated the annual N budget for New Zealand, and in doing so, demonstrated the importance of denitrification to the New Zealand environment. The total annual $\mathrm{N}$ input was estimated to be $976 \mathrm{Gg}$, with the largest input being $503 \mathrm{Gg}$ from $\mathrm{N}$-fixation by pasture legumes. The output of $\mathrm{N}$ was approximately $1079 \mathrm{Gg}$ per year, with the largest component being $307 \mathrm{Gg}$ from soil leaching to groundwater. Denitrification accounted for $153 \mathrm{Gg}$ and $35 \mathrm{Gg}$ of $\mathrm{N}$ losses in soil and waters respectively, or approximately $17 \%$ of total $\mathrm{N}$ output. Outputs of $\mathrm{N}$ exceed inputs by 102 Gg and Parfitt et al. (2006) attributed the discrepancy between inputs and outputs to uncertainties in estimating $\mathrm{NH}_{3}$ and $\mathrm{N}_{2}$ gas losses. The $\mathrm{N}$ budget was revisited in Parfitt et al. (2008) where the inputs and outputs were distributed in the order: leaching $>$ ammonia volatilization $>$ erosion $>$ produce $=$ denitrification .

Parfitt et al. (2008) delved further into the New Zealand $\mathrm{N}$ budget by estimating the future of the $\mathrm{N}$ budget under three percent growth of production from agriculture and a cap and trade system for $\mathrm{N}$. Under the three percent growth scenario, the increase in $\mathrm{N}$ input and output comes almost entirely from the increase in pastoral farming. The increased $\mathrm{N}$ loss to the environment under the three percent growth scenario is much more alarming than the cap and trade scenario. In fact, it appears that a three 
percent growth into the future would be unsustainable without changes in the current farming system. The agricultural industry is very important to New Zealand's economy and so it is important to manage $\mathrm{N}$ inputs at the source while maintaining production.

Like many countries around the world, New Zealand suffers from elevated $\mathrm{N}$ inputs from agriculture, mainly livestock farming. It is imperative to implement new technologies that would minimize excess $\mathrm{N}$ release to the environment, preferably utilizing denitrification as it is a permanent removal of $\mathrm{N}$ from ecosystems. These technologies should also be low-cost and low-maintenance in order to make these processes economically feasible to farmers in New Zealand as well as those around the world.

\subsection{Methods of Removing Nitrate through Denitrification}

Up to $75 \%$ of $\mathrm{N}$ added to soils can be removed before reaching the oceans, primarily through transformation of $\mathrm{N}$ and increased $\mathrm{N}$ storage (Burgin and Hamilton, 2007). Biological removal of $\mathrm{NO}_{3}{ }^{-}$occurs through assimilation by algae or microbes or through denitrification and DNRA, which are considered primary removal mechanisms (Camargo and Alonso, 2006; Burgin and Hamilton, 2007).

In order for denitrification to occur, $\mathrm{NO}_{3}{ }^{-}$must be present, there needs to be labile $\mathrm{C}$ available to act as an energy source for bacterial respiration, and there must be an absence of $\mathrm{O}_{2}$ because it is more energetically favourable than $\mathrm{NO}_{3}{ }^{-}$as an electron acceptor (Tiedje, 1988: Seitzinger et al., 2006). Most denitrifying bacteria are heterotrophic (the most common are in the genus Pseudomonas) and can use a wide range of $\mathrm{C}$ as an energy source (Hiscock et al., 1991). Denitrification occurs under an optimal $\mathrm{pH}$ range of $7.0-8.0$, and rates significantly decrease as temperature decreases (Hiscock et al., 1991). $\mathrm{N}_{2}$ gas production can also be supported using reduced iron, sulphides, or manganese as electron donors (rather than $\mathrm{NO}_{3}{ }^{-}$) (Seitzinger et al., 2006). 
Biological denitrification has been researched over the past few decades as a viable option to treat $\mathrm{NO}_{3}{ }^{-}$-laden groundwater. Examination of denitrification in a range of ecosystems, suggests that the right conditions exist in shallow groundwater to promote denitrification, except that there is insufficient organic $\mathrm{C}$ available to stimulate dissolved $\mathrm{O}_{2}$ and $\mathrm{NO}_{3}{ }^{-}$reduction (Seitzinger et al., 2006). A number of approaches have been investigated to increase the availability of $\mathrm{C}$ to denitrifying bacteria in soils and shallow aquifers (Schipper et al., 2010a). The main approaches are: land application, treatment wetlands, water table management, agricultural ditch management, addition of simple $\mathrm{C}$ sources to groundwater, and bioreactors.

\subsubsection{Land Application}

\subsubsection{Principles of Land Application}

Traditionally dairy farmers use waste stabilization ponds to treat farm effluent. These ponds operate through the anaerobic breakdown of the organic effluent followed by a facultative pond, with an aerobic layer over an anaerobic base (Bolan et al., 2004). This process removes a significant amount of contaminants, but unfortunately is not fully effective in nutrient removal. When ultimately discharged to receiving waterways, the high concentrations of $\mathrm{N}$ and phosphorus $(\mathrm{P})$ potentially lead to eutrophication (Wang et al., 2004). As a potential solution to this problem, land application of farm effluents is being encouraged in New Zealand and the waste stabilization ponds are slowly being phased out (Wang et al., 2004).

Land application is an alternative to releasing effluent to downstream waterways. This alternative is potentially beneficial because excess nutrients are used on fields as an alternative fertilizer. Regulations have been created in New Zealand to limit the amount of effluent that can be applied to pastures; $150-200 \mathrm{~kg} \mathrm{~N} \mathrm{ha}^{-1} \mathrm{yr}^{-1}$ is the maximum application to minimize potential leaching loss of $\mathrm{NO}_{3}{ }^{-}$to the groundwater (Wang et al., 2004). However, there is generally much more manure generated by livestock that either ends up being applied in excess to farmlands or ends up in groundwater and downstream water bodies. In general, the manure from livestock operations is applied to lands in the near vicinity of the farm dairy shed, which tends to lead to high frequency and high rates of application to the same land (Whalen et 
al., 2001). Furthermore, the chemical, physical, and biological properties of soil are changed by long-term manure applications, which could alter nutrient release patterns (Whalen et al., 2001). Bolan et al. (2004) observed that irrigation of dairy effluents

up to $150-200 \mathrm{~kg} \mathrm{~N} \mathrm{ha}^{-1}$ can result in large amounts of potassium $(\mathrm{K})$ being added to the soil, in turn increasing $\mathrm{K}$ uptake by pasture; this results in calcium and magnesium deficiencies increasing the occurrence of milk fever and grass staggers in livestock. Despite these issues, appropriate land application of wastes at dairy farms is wholly encouraged in New Zealand.

New Zealand also has a small pig operation that produces approximately 700,000 pigs (Wang et al., 2004). While $\mathrm{N}$ in dairy farm effluent is in the organic form, effluent from piggeries is in the form of $\mathrm{NH}_{4}{ }^{+}$. $\mathrm{NH}_{4}{ }^{+}$is highly volatile and waste application can lead to $\mathrm{N}$ loss through $\mathrm{NH}_{3}$ volatilization (Wang et al., 2004). Through the process of nitrification, $\mathrm{NH}_{4}{ }^{+}$is oxidized to $\mathrm{NO}_{3}{ }^{-}$, which can potentially be leached into downstream water bodies causing eutrophication or it can lead to $\mathrm{N}_{2} \mathrm{O}$ emissions, a greenhouse gas (Camargo and Alonso, 2006).

\subsubsection{Land Based Effluent Treatment Systems in New Zealand}

The soils of a commercial pine forest in Rotorua, New Zealand have been sprayirrigated with treated municipal wastewater from the city since 1991 (Tozer et al., 2005). The original design allowed for $312 \mathrm{~kg} \mathrm{~N} \mathrm{ha}^{-1} \mathrm{yr}^{-1}$ to be applied to the forest, but loading rates were increased up to a maximum of $399 \mathrm{~kg} \mathrm{~N} \mathrm{ha}^{-1} \mathrm{yr}^{-1}$; the forest is, on average, sprayed daily for 2 hours (Tozer et al., 2005). The application was designed to enhance $\mathrm{N}$ uptake by the trees and soil denitrification (Barton et al., 1999). The upland treatment plan, called the Rotorua Land Treatment System (RLTS), was designed to improve the water quality of Lake Rotorua, which has been eutrophic for many years (Tozer et al., 2005). However, soil denitrification accounted for less than $1 \%$ of total wastewater $\mathrm{N}$ applied annually (Barton et al., 1999). Denitrification at this site was limited by low-moisture content of the soil because there should have been enough $\mathrm{C}$ present for denitrification to occur (Barton et al., 1999). The soils are free-draining and are not able to hold sufficient moisture to limit $\mathrm{O}_{2}$ diffusion into the soil, which limited denitrification despite large amounts 
of $\mathrm{N}$ added to the soil (Barton et al., 1999; Tozer et al., 2005). Since the soils are free draining and do not hold much water, the water filled pore space (WFPS) is likely to be lower at this site and therefore not much denitrification is expected to occur (Lowrance et al., 1998).

Due to the overestimation of the denitrification potential of the forest soils, there has been an increase in $\mathrm{N}$ export to the Waipa stream and eventually to Lake Rotorua as a result of the spray-irrigation practice. Despite the increase in N export, the RLTS meets the water right requirement of $169 \mathrm{~kg} \mathrm{~N} \mathrm{ha}^{-1} \mathrm{yr}^{-1}$ leaving the Waipa stream (Tozer et al., 2005). An $\mathrm{N}$ budget of the system measured with natural abundance ${ }^{15} \mathrm{~N}$ tracers showed that about $50 \%$ of the added $\mathrm{N}$ was stored in the forest, the majority in the soil, while $13 \%$ was stored in wetland biomass, and only $2 \%$ was denitrified (Tozer et al. 2005).

Although denitrification rates have not been widely reported for other land-based systems, this case study illustrates upland denitrification rates do not contribute significant $\mathrm{N}$ removal if the upland soils are free-draining (Barton et al., 1999). However, upland soils with higher moisture contents do support higher denitrification rates (Lowrance et al., 1998). On an experimental field containing a year-round forage production system, liquid manure was applied onto four quadrants at different rates $\left(246,427,643\right.$, and $\left.802 \mathrm{~kg} \mathrm{~N} \mathrm{ha}^{-1} \mathrm{yr}^{-1}\right)$; high denitrification rates were found on the quadrants with the highest soil moisture and high rates of manure application (i.e. high $\mathrm{N}$ loads and DOC) (Lowrance et al., 1998). In this case, the two year average rate of denitrification ranged from $11-37 \%$ of the applied $\mathrm{N}$, however, the higher rates of denitrification also coincided with higher rates of $\mathrm{N}_{2} \mathrm{O}$ evolution; the average $\mathrm{N}_{2} \mathrm{O}$ production over the four quadrants was $29 \%$ of denitrification.

\subsubsection{Treatment Wetlands}

For many years, treatment wetlands have been used for the treatment of agricultural, residential, and municipal wastewaters due to the low cost and simple design (Kadlec and Knight, 1996). Treatment wetlands can either be constructed wetlands for the purpose of treatment or natural wetlands and riparian buffers that receive point source 
inputs (Kadlec, 2009). Constructed treatment wetlands offer a low-energy (i.e. lowmaintenance and operation costs) alternative to other waste treatment technologies for livestock and other agricultural farms (Knight et al., 2000). Waste tends to be concentrated in livestock farms and can easily be diverted and subjected to treatment in wetlands (Knight et al., 2000). C is often the limiting factor for denitrification in wetlands, because the organic C content of the wetland soils can be low (Leverenz et al., 2010). Denitrification can also be limited due to competition with wetland plants for groundwater $\mathrm{NO}_{3}{ }^{-}$(Hanson et al., 1994). Decomposition of plant litter high in $\mathrm{N}$ leads to mineralization and subsequent nitrification releasing the temporarily stored $\mathrm{N}$ back to the water column. However, wetlands can support high rates of denitrification. For example, in a swine lagoon wastewater treatment wetland in North Carolina, very high rates of denitrification were measured, particularly in the suspended sludge layer (Hunt et al., 2009). Similarly, denitrification accounted for up to $59 \%$ of $\mathrm{NO}_{3}{ }^{-}$removal in a riparian wetland receiving $\mathrm{NO}_{3}{ }^{-}$-laden groundwater in Kingston, Rhode Island (Hanson et al., 1994) and was also the main mechanism for $\mathrm{NO}_{3}{ }^{-}$removal in a riparian wetland receiving sewage that was spray-irrigated onto a nearby forest in Whangamata, New Zealand (Schipper et al., 1993).

Although $\mathrm{NO}_{3}{ }^{-}$tends to be the limiting factor for denitrification in natural wetlands, if the input of $\mathrm{NO}_{3}{ }^{-}$to the wetland is high while the $\mathrm{C}$ content of the wastewater is low, then an energy source for denitrifying bacteria can be the limiting factor. This is particularly true in subsurface treatment wetlands, which are typically designed with a rock medium that inhibits the $\mathrm{C}$ from plant debris reaching the subsurface water (Leverenz et al., 2010). To combat this problem, additional $\mathrm{C}$ can be added to treatment wetlands in order to promote denitrification. Artificial marshes were created near a water reclamation facility in Santee, California to treat excess $\mathrm{NO}_{3}{ }^{-}$not removed by the treatment facility (Gersbert et al., 1983). Methanol was added to the marshes to supplement $\mathrm{C}$ supply for denitrifiers, and this raised $\mathrm{NO}_{3}{ }^{-}$removal efficiencies to $97 \%$. Plant biomass as an additional source of $\mathrm{C}$ for denitrification was also tested in the artificial marshes (Gersberg et al., 1983). While $\mathrm{NO}_{3}{ }^{-}$removal was lower than when methanol was added at 91\%, the biomass was produced on site and reduced costs. Similarly, Songliu et al. (2009) added $25 \mathrm{mg} \mathrm{L}^{-1}$ glucose to a 
treatment wetland in Beijing, China and demonstrated that the $\mathrm{C}$ source was a controlling factor in denitrification. The added glucose caused an additional $10 \%$ of $\mathrm{NO}_{3}{ }^{-}$removal but also promoted the accumulation of $\mathrm{NO}_{2}{ }^{-}$, which is toxic to plants and microorganisms. With the additional labile $\mathrm{C}$ source, the transformation rate of $\mathrm{NO}_{3}{ }^{-}$to $\mathrm{NO}_{2}{ }^{-}$occurs rapidly, while the denitrification process is slower and leads to excess $\mathrm{NO}_{2}{ }^{-}$in the wetland. While addition of soluble sources of $\mathrm{C}$ can increase denitrification, there remain questions about practicality and costs.

Not all $\mathrm{N}$ removed in wetlands should be attributed to denitrification. For example, $\mathrm{NO}_{3}{ }^{-}$concentrations in the water decreased with time in a seepage wetland receiving groundwater inputs from a grazed dairy catchment in Waikato, New Zealand (Zaman et al., 2009). However, the rate of $\mathrm{NO}_{3}{ }^{-}$removal was substantially higher than $\mathrm{N}_{2} \mathrm{O}$ and $\mathrm{N}_{2}$ gas production, which suggested that denitrification was not the primary $\mathrm{NO}_{3}{ }^{-}$ removal pathway (Zaman et al., 2009). Since gas production only accounted for 6 $7 \%$ of removal, the majority of $\mathrm{NO}_{3}{ }^{-}$was most likely taken up by plants, immobilized by microbes, or removed through DNRA. The wetland also acted as a source of $\mathrm{N}_{2} \mathrm{O}$ during the initial few hours of the study when $\mathrm{NO}_{3}{ }^{-}$concentrations were high. As $\mathrm{NO}_{3}{ }^{-}$decreased, microbes may then have used $\mathrm{N}_{2} \mathrm{O}$ as an electron acceptor and further reduced $\mathrm{N}_{2} \mathrm{O}$ to $\mathrm{N}_{2}$. This suggested that wetlands can act as a source of $\mathrm{N}_{2} \mathrm{O}$ when $\mathrm{NO}_{3}{ }^{-}$concentrations are high.

While it appears that wetlands can be effective in removing $\mathrm{NO}_{3}{ }^{-}$from wastewater, there are also disadvantages in utilizing wetlands for such purposes. Besides denitrification, wetlands remove $\mathrm{N}$ by $\mathrm{NH}_{4}{ }^{+}$volatilization, adsorption, assimilation, and sedimentation (Hunt et al., 2009). These pathways are not permanent $\mathrm{N}$ sinks; only denitrification or anammox completes the cycle back to $\mathrm{N}_{2}$ gas. Assimilation of $\mathrm{NO}_{3}{ }^{-}$into plant biomass will eventually be released as mineral $\mathrm{N}\left(\mathrm{NH}_{4}{ }^{+}\right.$and $\left.\mathrm{NO}_{3}{ }^{-}\right)$ unless the plant biomass is harvested and removed. The $\mathrm{NO}_{3}{ }^{-}$may be released from the sediment back into the water if not assimilated by microbes or plants with adsorption and sedimentation. $\mathrm{N}$ uptake in wetlands decreases with time as plants become N saturated unless harvested and new plants added (Brix, 1997). 
Denitrification is the only way to permanently remove $\mathrm{NO}_{3}{ }^{-}$from ecosystems, although the production of $\mathrm{N}_{2} \mathrm{O}$ during the process can contribute to atmospheric problems. Wetlands promote denitrification, but incomplete denitrification can lead to increased $\mathrm{N}_{2} \mathrm{O}$ emissions when $\mathrm{NO}_{3}{ }^{-}$concentrations are high, thereby shifting the problem from water pollution to greenhouse gas emission (Zaman et al., 2008). It is important to further study the role of denitrification in wetlands since some studies have reported that denitrification only accounts for a small percentage of $\mathrm{NO}_{3}{ }^{-}$ removal concurrent with high levels of $\mathrm{N}_{2} \mathrm{O}$ production.

\subsubsection{Water Table Management}

Artificial drainage of agricultural fields can increase crop yields and reduce the risk of saturated soils and ponding on fields (Strock et al., 2007), but the drainage water tends to be high in nutrients from fertilizer application. Drainage systems are typically shallow, direct pipelines to surface waters, discharging high nutrient water directly to streams and downstream ecosystems (Dinnes et al., 2002). The drainage water can be controlled so that the soils in the outflow ditch stay wetter, which then promotes denitrification and reduces $\mathrm{NO}_{3}{ }^{-}$concentrations (Gilliam and Skaggs, 1986). There are several techniques for managing these drainage systems to reduce elevated nutrient discharges, including keeping the water table at a stable and elevated height or managing the drainage water as it leaves the field.

Tillage of agricultural fields aerates the soil, which increases microbial activity and $\mathrm{N}$ mineralization rates in the soil (Dinnes et al., 2002). One way to slow the mineralization process is by raising the water table close to the soil surface. Increasing the height of the water table restricts $\mathrm{O}_{2}$ diffusion into soil pores creating anaerobic conditions suitable for denitrification (Elmi et al., 2002). Two different approaches to water table management can be undertaken; keeping the water table stable and close to the surface, or managing the water table at different depths. In a study on a corn/soybean rotation in Iowa, controlling drainage through water table management decreased $\mathrm{N}$ flux by $70 \%$ without affecting yield (Woli et al., 2010). Similarly, keeping the water table stable within $0.6 \mathrm{~m}$ of the soil surface has been 
shown to reduce $\mathrm{NO}_{3}{ }^{-}$concentrations significantly without affecting corn yield on a field in Quebec, Canada (Elmi et al., 2002).

Although water table management appears to be a viable tool to reduce $\mathrm{NO}_{3}{ }^{-}$in drainage waters, there are several disadvantages. (i) In years of heavy rain, the treatment must be discontinued to allow drainage of the fields or crop yields will substantially reduce. This problem could potentially be solved by more rigorous management or by automating the drainage system. (ii) Managing $\mathrm{N}$ by raising and lowering the water table requires that the water table be near the surface during the growing season because this is also the seasonal period of high denitrification rates (Jacinthe et al., 1999). The disadvantage in terms of crop production is that while a high water table may stimulate denitrification, the anaerobic conditions can damage plant roots and decrease yields (Jacinthe et al., 1999). (iii) Denitrification can increase $\mathrm{N}_{2} \mathrm{O}$ production. Rates of $\mathrm{N}_{2} \mathrm{O}$ production have been examined in comparison to $\mathrm{N}_{2}$ production. $\mathrm{N}_{2}$ generally comprises a much larger portion of the denitrification end product than $\mathrm{N}_{2} \mathrm{O}$ under water table management, but this was not the case under free drainage (Elmi et al., 2005). (iv) Water table management is only economically feasible on fields that have a $1 \%$ slope or less (Dinnes et al., 2002). At

a $1 \%$ slope, the difference in water table height would be $1 \mathrm{~m}$ leading to the need for multiple drainage control structures or increased management time (Dinnes et al., 2002).

\subsubsection{Agricultural Ditches and Streams}

Agricultural ditches are drainage ditches that divert water away from agricultural fields and agricultural streams are streams that receive runoff from agriculture. In this review, they are both referred to as agricultural streams. $\mathrm{NO}_{3}{ }^{-}$removal from agricultural streams occurs through denitrification as well as microbial and plant uptake (Strock et al., 2007). While streams have a high capacity for denitrification, they often have low denitrification efficiency during the period of the year where they receive high flow and high $\mathrm{NO}_{3}{ }^{-}$(Royer et al., 2004; Mulholland et al., 2008).

Denitrification in agricultural streams tends to be $\mathrm{C}$ limited as $\mathrm{NO}_{3}{ }^{-}$concentrations are generally high (Inwood et al., 2007). 
In agricultural streams, denitrification most likely occurs in the benthic sediments (Arango et al., 2007). In fact, denitrification associated with plants was an order of magnitude less than denitrification associated with benthic sediments (Schaller et al., 2004). Denitrification in benthic sediments is positively related to $\mathrm{NO}_{3}{ }^{-}$ concentrations within the stream, suggesting that as $\mathrm{NO}_{3}{ }^{-}$concentrations increase, denitrification will increase as well (Arango et al., 2007; Inwood et al., 2007). Denitrification is highest in the upper $5 \mathrm{~cm}$ of benthic sediment and then largely decreases with depth (Inwood et al., 2007).

Mulholland et al. (2008) describes the effects of stream size and $\mathrm{N}$ loading rates: at low $\mathrm{N}$ loading rates, $\mathrm{N}$ removal is high in small streams, but is limited in large streams due to $\mathrm{N}$ availability. Under moderate loading rates, removal in small streams decreases because they are oversupplied with $\mathrm{N}$, but the larger streams begin to respond in terms of denitrification and $\mathrm{N}$ export decreases. At high loading rates, removal becomes ineffective across all stream sizes and the stream network exports most of the $\mathrm{N}$ input.

Traditional drainage ditches are maintained by removing woody vegetation and sediment deposits because the main priority is getting water off the field quickly. The disadvantage in terms of water quality is that when the sediment is excavated from the ditch, vegetation and microbial communities are also unintentionally removed, disrupting the $\mathrm{N}$ cycling process (Strock et al., 2007). After each maintenance activity, denitrification and $\mathrm{N}$ uptake will be greatly reduced for some period until the system is re-stabilized and re-vegetated.

Two-stage channel systems (Figure 2.2) have been developed to maximize physical stability of agricultural drainage ditches while maintaining function and capacity to remove water from fields. While maintenance of ditches usually includes removing benches (small stable floodplains), the two-stage design calls for a wider top portion of the ditch to allow for larger benches which will stabilize the channels during high flows (Powell et al., 2007). The approach consists of an inset channel (fluvial 
channel within the ditch) to convey bankfull discharge (the discharge that is just contained within the banks), a floodplain for the inset channel, and an adequate capacity above the benches to reduce the likelihood that flow will overtop the ditch banks (Powell et al., 2007). While these systems may provide greater stability, increased water flow capacity, increased denitrification, greater nutrient assimilation, and reduced maintenance, two-stage systems have not been widely studied.

Furthermore, there is a larger initial investment included in widening the channel and the volume of material that would need to be excavated to construct the floodplain (Powell et al., 2007).



Figure 2.2: A simple diagram demonstrating a two-stage channel; a two-stage channel is an agricultural ditch designed to maintain physical stability while preserving function in terms of removing water quickly from agricultural fields.

Streams receiving runoff from agriculture can be a source of $\mathrm{N}_{2} \mathrm{O}$. Generally, $<1 \%$ of $\mathrm{NO}_{3}{ }^{-}$denitrified in aquatic systems is released as $\mathrm{N}_{2} \mathrm{O}$, but it could be as high as $6 \%$ depending on high $\mathrm{NO}_{3}{ }^{-}$concentrations and low $\mathrm{pH}$ (Seitzinger, 1988). There are only a few studies which published measurements of $\mathrm{N}_{2} \mathrm{O}$ yields in aquatic systems. In one study, $\mathrm{N}_{2} \mathrm{O}$ production rates were shown to be higher in a study of 12 headwater streams in southwest Michigan, USA receiving agricultural runoff, than rates observed for rivers, lakes, and estuaries (Beaulieu et al., 2009). 


\subsubsection{Addition of Simple Carbon Sources to Groundwater}

Many aquifers are anaerobic as they are beneath the soil surface where they receive little $\mathrm{O}_{2}$ little $\mathrm{O}_{2}$ input. When $\mathrm{NO}_{3}{ }^{-}$concentrations are high and $\mathrm{O}_{2}$ low, labile $\mathrm{C}$ source is the main main limitation for denitrification. To promote denitrification in aquifers with high $\mathrm{NO}_{3}{ }^{-}$ $\mathrm{NO}_{3}{ }^{-}$concentrations, researches have injected a range of simple $\mathrm{C}$ sources into aquifers to act as aquifers to act as an energy source for the denitrifiers (

Table 2-1; Soares, 2000; Hiscock et al., 1991).

Table 2-1: The efficiency of various simple $C$ substrates that have been tested in order to promote denitrification in aquifers.

\begin{tabular}{llll}
\hline Carbon Source & $\begin{array}{l}\text { Nitrate Removal } \\
\text { Efficiency }\end{array}$ & Scale & Reference \\
\hline Methanol injection & $50 \%$ & Field & Kruithof et al., 1985 \\
Ethanol injection & $95 \%$ & Treatment Plant & Roennefahrt, 1986 \\
& $72 \%$ & Treatment Plant & Richard, 1989 \\
Ethanol in situ & $50 \%$ & Field & Janda et al., 1988 \\
Acetate injection & $92 \%$ & Field & Bockle et al., 1986 \\
& $75 \%$ & Field & Kahn and Spalding, 2004 \\
Vegetable oil in situ & $\begin{array}{l}93 \% \text { (not } \\
\text { sustainable } \\
\text { longer than 10 } \\
\text { weeks without } \\
\text { further } \\
\text { injections of oil) } \\
90 \%\end{array}$ & Field & Hunter, 2001 \\
& Field & \\
Cotton bioreactor & & Rocca et al., 2005 \\
\hline
\end{tabular}

Addition of methanol has been shown to remove $50 \%$ of $\mathrm{NO}_{3}{ }^{-}$in aquifers and is the least expensive of all the simple $\mathrm{C}$ sources, but it is not permitted for use as treatment in potable water supplies in some countries as it can be toxic to humans (Kruithof et al., 1985; Soares, 2000). Similarly, above ground systems that inject ethanol into aquifers have achieved $\mathrm{NO}_{3}{ }^{-}$removal rates of $95 \%$ (Roennefahrt, 1986) and $72 \%$ (Richard, 1989). In situ experiments with ethanol have also been tested and have been effective in removing up to $50 \% \mathrm{NO}_{3}{ }^{-}$(Janda et al., 1988). 
Acetate is another simple $\mathrm{C}$ source that has been studied as a potential energy source for denitrifying microbes. By amending aquifer water with acetate and passing it through a fixed bed of granulated reactive $\mathrm{C}$ before being re-injected back into the aquifer, $\mathrm{NO}_{3}{ }^{-}$concentrations were reduced to meet the required regulatory standards (Bockle et al., 1986). Through a series of injection wells, acetate was added to an aquifer and subsequent $\mathrm{NO}_{3}{ }^{-}$concentrations decreased by $75 \%$ over a two month period (Khan and Spalding, 2004). In situ use of vegetable oil-coated sand as a C source has also been shown to be very effective in $\mathrm{NO}_{3}{ }^{-}$removal, although efficiency declined with time (Hunter, 2001). Initially enough $\mathrm{NO}_{3}{ }^{-}$was removed to comply with EPA standards of $10 \mathrm{mg} \mathrm{N} \mathrm{L}^{-1}$, but by the end of the 30 week study, the majority of the oil was consumed suggesting that oil would have to be injected every $10-20$ weeks in order to remain effective (Hunter, 2001).

Solid $\mathrm{C}$ sources have also been tested for their effectiveness in $\mathrm{NO}_{3}{ }^{-}$removal. For example, water pumped through a heterotrophic denitrification reactor utilizing cotton removed $90 \%$ of the $\mathrm{NO}_{3}{ }^{-}$present in the water, although there were high levels of TOC output (Rocca et al., 2005).

One of the most prevalent problems in using simple $\mathrm{C}$ sources is clogging; for above ground reactors, the filters tend to clog if they are not flushed regularly and for in situ systems, the aquifer clogs with time (Soares, 2000). Previous studies have attributed clogging of filters to increased microbial biomass (Soares, 2000) or gas buildup (Soares et al., 1991).

While some success has been achieved using liquid and other simple $\mathrm{C}$ sources in groundwater treatment to promote denitrification, there are many disadvantages. These systems are complex and generally require above ground reactors or a system of pumps which require maintenance and continued operational costs. In many cases, not enough $\mathrm{NO}_{3}{ }^{-}$was removed to comply with the required environmental standards (e.g. Boussaid et al., 1988). There have also been issues with biofouling, gas build up, and clogging (Robertson et al., 2007). 


\subsubsection{Bioreactors}

The removal of $\mathrm{N}$ from groundwater can occur through denitrification or discharge of $\mathrm{NO}_{3}{ }^{-}$to surface waters (Galloway et al., 2003). Many technologies have been put into place to remove $\mathrm{NO}_{3}{ }^{-}$from groundwater, including anion exchange resins, reverse osmosis, and biological denitrification (reviewed in Hiscock et al., 1991 and Soares, 2000), however, these technologies are very complex and expensive to maintain. As an inexpensive, low-maintenance solution, in situ bioreactors within the groundwater have been developed using a permeable barrier with an organic $\mathrm{C}$ source.

Reactive porous media (e.g. sawdust, woodchips) has been used as an organic C source rather than a liquid carbon source in bioreactors (Schipper et al., 2010a). The advantages of using a reactive porous media barrier is that once installed, the barrier does not require any reservoirs or plumbing systems and require no energy or maintenance for long periods of time (Hunter, 2001; Robertson and Cherry, 1995). The three main bioreactors types are: denitrification beds, denitrification layers, and denitrification walls (Schipper et al., 2010a).

\subsubsection{Denitrification Beds}

A denitrification bed is a lined container filled with organic matter and high concentrations of $\mathrm{NO}_{3}{ }^{-}$as a point source is pumped through the bed and subsequently denitrified (Robertson et al., 2005). $\mathrm{NO}_{3}{ }^{-}$removal rates of $2-5 \mathrm{~g} \mathrm{~N} \mathrm{~m}^{-3} \mathrm{~d}^{-1}$ have been found at sites that received $\mathrm{NO}_{3}{ }^{-}$-rich groundwater plumes from septic tanks. However, the site was $\mathrm{N}$-limited, so this low rate accounted for $87-98 \%$ of the $\mathrm{NO}_{3}{ }^{-}$ entering the system (Robertson et al., 2005). Beds treating effluent from drainage tiles in Canada achieved $\mathrm{NO}_{3}{ }^{-}$removal rates of approximately $5-30 \mathrm{~g} \mathrm{~N} \mathrm{~m}^{-3} \mathrm{~d}^{-1}$, depending on temperature, corresponding to $58 \% \mathrm{NO}_{3}{ }^{-}$removal (Robertson et al., 2000). In Iowa, a denitrification bed receiving drainage from tiles removed $6.4 \mathrm{~g} \mathrm{~N}$ $\mathrm{m}^{-3} \mathrm{~d}^{-1}$ corresponding to $33 \%$ removal (Woli et al., 2010). Beds in stream banks had removal rates of $3.2-9.8 \mathrm{~g} \mathrm{~N} \mathrm{~m}^{-3} \mathrm{~d}^{-1}$, or $20-30 \%$ of the $\mathrm{NO}_{3}{ }^{-}$present (van Driel et al., 2006). $\mathrm{NO}_{3}{ }^{-}$removal rates were also reported for larger denitrification beds in New Zealand receiving various effluents (Schipper et al., 2010b). A denitrification bed receiving domestic effluent from a subdivision on Lake Taupo removed 
anywhere from 0 to $11 \mathrm{~g} \mathrm{~N} \mathrm{~m}^{-3} \mathrm{~d}^{-1}$, while a bed in Northland receiving dairy effluent removed on average $1.4 \mathrm{~g} \mathrm{~N} \mathrm{~m}^{-3} \mathrm{~d}^{-1}$, and a bed in Karaka, south of Auckland, receiving glasshouse effluent removed $5-10 \mathrm{~g} \mathrm{~N} \mathrm{~m}^{-3} \mathrm{~d}^{-1}$ (Schipper et al., 2010b).

Denitrification beds rely on wood chips as an inexpensive organic matter source because of its high hydraulic conductivity (Schipper et al., 2010a). A favourable hydraulic gradient is maintained by lowering the water table across the bed (Schipper et al., 2010a). In a recent study, $\mathrm{NO}_{3}{ }^{-}$removal rates were measured in experimental barrels of nine different $\mathrm{C}$ media over a two year period (Cameron and Schipper, 2010). Water was pumped through the $0.2 \mathrm{~m}^{3}$ barrels and the effluent was sampled for $\mathrm{NO}_{3}{ }^{-}$. The $\mathrm{C}$ media included five different particle sizes of softwood, hardwood chips, maize cobs, wheat straw, and green waste. $\mathrm{NO}_{3}{ }^{-}$removal was greatest in the barrels with maize cob, and in general, the more labile $\mathrm{C}$ sources removed greater amounts of $\mathrm{NO}_{3}{ }^{-}$than the wood media. After two years, the labile media continued to have higher $\mathrm{NO}_{3}{ }^{-}$removal rates than wood media, but it is unknown how long these rates could be sustained. Using labile $\mathrm{C}$ media may require more frequent replacement of the $\mathrm{C}$ source.

\subsubsection{Denitrification Layers}

Denitrification layers are horizontal layers of $\mathrm{C}$ material that have been installed under the soil surface (Robertson and Cherry, 1995). There has been little work on denitrification layers, but they are thought to be ideal for use under weeping tiles in septic tank drainage fields or under effluent-irrigated topsoils. A denitrification layer located in New Zealand under dairy effluent-irrigated topsoils found that denitrification was not high enough to significantly limit $\mathrm{NO}_{3}{ }^{-}$leaching (Schipper and McGill, 2008), while another study in Canada near a septic system showed removal rates of $2.6 \mathrm{~g} \mathrm{~N} \mathrm{~m}^{-3} \mathrm{~d}^{-1}$ or $80 \%$ of the $\mathrm{NO}_{3}{ }^{-}$input (Robertson et al., 2000).

\subsubsection{Denitrification Walls}

Denitrification walls are vertical walls of $\mathrm{C}$ material installed in the groundwater perpendicular to flow (Robertson and Cherry, 1995; Schipper and Vojvodic-Vukovic, 1998; Jaynes et al., 2008) (Figure 2.3). Walls may intercept the natural groundwater 
flow path or paths that have been altered by drainage systems (Schipper et al., 2010a). Denitrification walls have been created using sawdust (Robertson and Cherry, 1995; Schipper and Vojvodic-Vukovic, 1998) or woodchips (Jaynes et al., 2008). The C source should be selected based on site-specific characteristics, such as permeability requirements, hydraulic retention time, the acceptable frequency of maintenance, and availability of local C sources (Robertson et al., 2000). Denitrification walls are likely limited to land areas with high concentrations of $\mathrm{NO}_{3}{ }^{-}$including areas near septic tanks, sites where wastes are applied to land, or managed agricultural sites (e.g. tile drain systems) where N loading is high (Schipper and Vojvodic-Vukovic, 1998). Further constraining the use of walls is that the groundwater table must be near the surface and an inexpensive $\mathrm{C}$ source needs to be available.

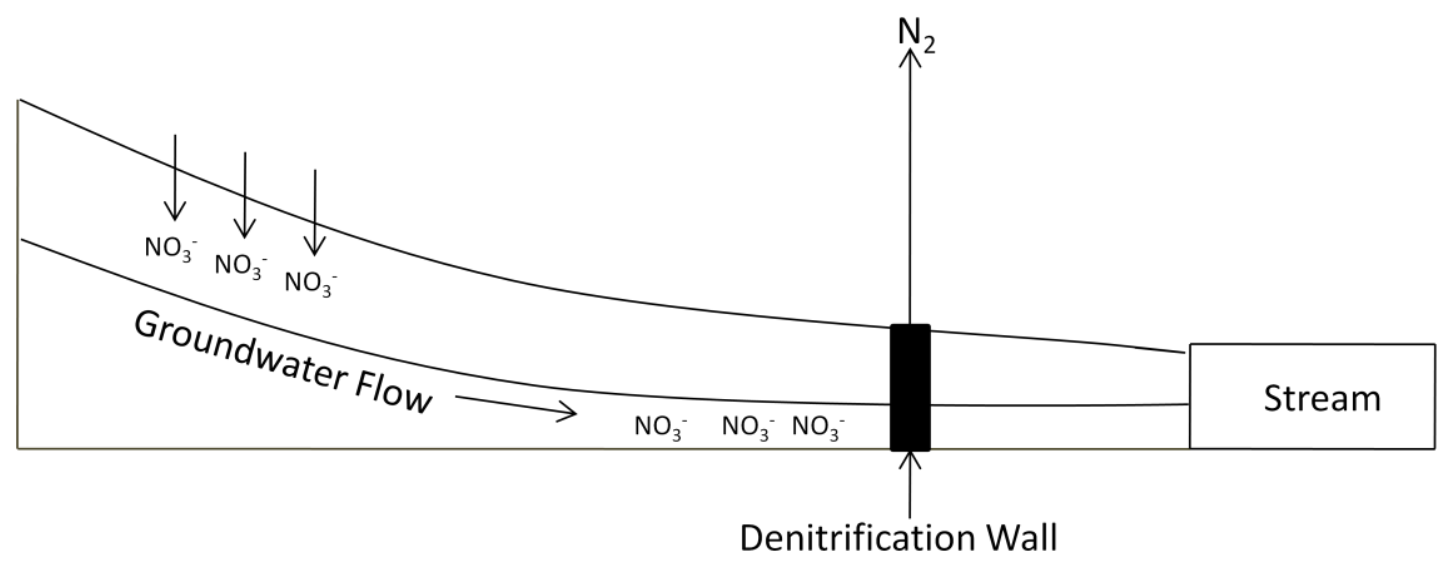

Figure 2.3: A diagram of a denitrification wall, a permeable reactive barrier designed to remove nitrate $\left(\mathrm{NO}_{3}{ }^{-}\right)$from groundwater.

\section{$N$ removal in denitrification walls}

Very few denitrification walls have been constructed and studied; the first wall was installed near a septic tank site to intercept the water table in Canada in 1992 (Robertson and Cherry, 1995). The wall was placed downgradient of the septic tank discharge and intercepted the plume flowpath, with $\mathrm{NO}_{3}{ }^{-}$concentrations up to $55 \mathrm{mg}$ $\mathrm{N} \mathrm{L}^{-1}$. Over the course of a year, the wall removed between $72 \%$ (during peak water usage in September) to $97 \%$ of $\mathrm{NO}_{3}{ }^{-}$, corresponding to a removal rate of $3.2-6 \mathrm{~g} \mathrm{~N}$ $\mathrm{m}^{-3} \mathrm{~d}^{-1}$. 
Schipper and Vojvodic-Vukovic (1998) also used sawdust as a C source to construct a denitrification wall in New Zealand on a dairy farm spray-irrigated with effluent from the nearby dairy factory. The New Zealand wall (35 m long, $1.5 \mathrm{~m}$ deep, and $1.5 \mathrm{~m}$ wide) was larger than the one described by Robertson and Cherry (1995) (1.2 $\mathrm{m}$ long, $0.8 \mathrm{~m}$ deep, and $0.6 \mathrm{~m}$ wide). Incoming groundwater contained $5-16 \mathrm{mg} \mathrm{N}$ $\mathrm{L}^{-1}$ while concentrations in the wall were $<2 \mathrm{mg} \mathrm{N} \mathrm{L}^{-1}$ thereby significantly reducing the amount of $\mathrm{NO}_{3}{ }^{-}$in the groundwater, by a rate of $0.252 \mathrm{~g} \mathrm{~N} \mathrm{~m}^{-3} \mathrm{~d}^{-1}$.

In contrast to sawdust, wood chips are also a possible $\mathrm{C}$ source in denitrification walls. Two walls using wood chips were constructed on either side of a tile drain which received drainage from an agricultural field in Iowa (Jaynes et al., 2008). Over a 5 year period of study, $\mathrm{NO}_{3}{ }^{-}$concentrations were reduced from $20-25 \mathrm{mg} \mathrm{N} \mathrm{L}^{-1}$ by approximately $60 \%$ to an average of $8.8 \mathrm{mg} \mathrm{N} \mathrm{L}^{-1}$, which is below the EPA standard of $10 \mathrm{mg} \mathrm{N} \mathrm{L}^{-1}$; this corresponds to a removal rate of $0.622 \mathrm{~g} \mathrm{~N} \mathrm{~m}^{-3} \mathrm{~d}^{-1}$. Although removal rates varied across these three studies, denitrification walls are typically $\mathrm{N}$ limited and so $\mathrm{NO}_{3}{ }^{-}$removal rates are functions of $\mathrm{NO}_{3}{ }^{-}$concentrations (Schipper and Vojvodic-Vukovic, 1998).

\section{Hydrology of denitrification walls}

Denitrification walls should be located downgradient of the $\mathrm{NO}_{3}{ }^{-}$source, so that flow through the wall is governed by Darcy's Law (Schipper et al., 2010a). Flow rates are likely to be $0.05-0.5 \mathrm{~m} \mathrm{day}^{-1}$ and retention times are likely to be $3-10$ days depending on wall width (Schipper et al., 2010a). The desired wall location must be investigated to determine the hydraulic gradient and the depth and extent of $\mathrm{NO}_{3}{ }^{-}$ plumes under all seasonal changes, because if the wall has a lower hydraulic conductivity than the aquifer, the plume will be rerouted under or around the wall rendering it ineffective (Schipper et al., 2004; Vogan et al., 1999). It can be difficult to accurately measure groundwater velocity, but in-well meters may be a solution (Vogan et al., 1999). Depth to the water table should also be noted during the site analysis as it is unlikely to be cost effective to place the $\mathrm{C}$ material deeper than a few meters (Schipper et al., 2010a). 
A few studies have noted problems associated with decreases in hydraulic conductivity in the wall compared to the aquifer. Schipper et al. (2004) constructed a second denitrification wall in Cambridge, New Zealand in 1999, but observed that the majority of groundwater flowed under the wall decreasing potential $\mathrm{NO}_{3}{ }^{-}$removal. This may have been a result of mixing of saturated sands during construction of the denitrification wall which caused a decline in aquifer hydraulic conductivity (Barkle et al., 2008).

\section{Adverse Effects of denitrification walls}

During the initial period of operation for denitrification walls, dissolved organic $\mathrm{C}$ (DOC) may be released decreasing the dissolved $\mathrm{O}_{2}$ in receiving waters (Robertson and Cherry, 1995). This is of less concern in walls where the aquifer may consume the DOC before discharge, in contrast to denitrification beds which directly discharge to receiving water. At sites where DOC leaching is not permissible, control measures may include installing additional treatment, collection of the effluent for disposal elsewhere, or maintaining high flow rates during start-up to minimize export of DOC (Schipper et al., 2010a).

A byproduct of denitrification is $\mathrm{N}_{2} \mathrm{O}$ (an important greenhouse gas), but very few studies have looked at the production and release of $\mathrm{N}_{2} \mathrm{O}$ in denitrification walls. Fluxes of $\mathrm{N}_{2} \mathrm{O}$ were observed over a two year period from a denitrification wall and the adjacent pasture; fluxes were greater from the wall (average $0.31 \mathrm{~g} \mathrm{~N} \mathrm{ha}^{-1} \mathrm{~h}^{-1}$ ) than the pasture $\left(0.05 \mathrm{~g} \mathrm{~N} \mathrm{ha}^{-1} \mathrm{hr}^{-1}\right)$ (Schipper et al., 2010a). It is expected that with complete or near-complete removal of $\mathrm{NO}_{3}{ }^{-}$in a denitrification wall, $\mathrm{N}_{2} \mathrm{O}$ production will be lower than what has been observed when $\mathrm{NO}_{3}{ }^{-}$removal is not complete (Schipper et al., 2010a). This has been observed in denitrification beds where $\mathrm{N}_{2} \mathrm{O}$ production accounted for $0.6 \%$ of the $\mathrm{NO}_{3}{ }^{-}$removed by the bed and that the rate was lower $(0.19 \%)$ during the summer months when there was complete $\mathrm{NO}_{3}{ }^{-}$removal (Elgood et al., 2010). The $\mathrm{N}_{2} \mathrm{O}$ production in the denitrification bed is less than some $\mathrm{N}$-polluted rivers and streams and in the same range as fertilized agricultural systems 
(Elgood et al., 2010). While bioreactors do produce $\mathrm{N}_{2} \mathrm{O}$, it is the ratio of $\mathrm{N}_{2} \mathrm{O}$ produced relative to $\mathrm{NO}_{3}{ }^{-}$removed that is important when examining potential impacts of the bioreactor. This is important because $\mathrm{N}_{2} \mathrm{O}$ production will also occur in other treatment systems utilizing denitrification, not just bioreactors.

\section{Sustainability of denitrification walls}

The long-term effectiveness of a denitrification wall is not known because there are no examples of a wall that has failed due to $\mathrm{C}$ depletion. Two factors will affect longevity; the availability of labile $\mathrm{C}$ and the maintenance of hydraulic conductivity (Schipper et al., 2010a).

A study on the wall in New Zealand (Schipper et al., 2005) showed that denitrification walls can operate for at least seven years. There were no measureable losses in C, similar to Robertson et al. (2000), who showed that less than $10 \%$ of C was lost after seven years. Microbial biomass and available $\mathrm{C}$ was found to decrease only slightly after seven years, indicating that $\mathrm{C}$ continued to be released from the decaying sawdust (Schipper et al., 2005). Moorman et al. (2010) presented data on wood loss in a previously described wood-chip denitrification wall (Jaynes et al., 2008) after nine years. Wood chips had been enclosed in mesh litter bags and buried at varying depths at the time of wall construction; the litter bags were recovered from depths of $90-100 \mathrm{~cm}$ and $155-170 \mathrm{~cm}$ in 2003 (four years after installation), 2004 (after five years), and 2008 (after nine years). The study showed that the loss of wood averaged around $50 \%$ after $4-5$ years and then increased to $75 \%$ after nine years at the $90-100 \mathrm{~cm}$ depth, but less than $13 \%$ of the wood was decomposed at the $155-170 \mathrm{~cm}$ depth after 9 years indicating that $\mathrm{NO}_{3}{ }^{-}$removal will continue to be supported at deeper depths. C decomposition was faster in the shallower layer most likely due to aerobic decomposition.

Robertson (2010) looked at $\mathrm{N}$ removal in woodchip media of varying age using laboratory column tests. Fresh pine and hardwood media were collected from local sawmills in Canada while aged samples were collected from two bioreactors: Avon, 
which was two years old (Robertson and Merkley, 2009) and Wildwood, which was seven years old (van Driel, et al., 2006). The study showed that $\mathrm{NO}_{3}{ }^{-}$removal rates in aged media $\left(9-12 \mathrm{~g} \mathrm{~N} \mathrm{~m}^{-3} \mathrm{~d}^{-1}\right)$ were up to $50 \%$ lower than the fresh woodchips $\left(15-23 \mathrm{mg} \mathrm{N} \mathrm{m}^{-3} \mathrm{~d}^{-1}\right)$.

Schipper and Vojvodic-Vukovic (2001) reported that denitrifying enzyme activity (DEA) declined after five years to $10 \%$ of the activity measured during the first year of installation. After seven years, the denitrification wall in New Zealand still showed declining DEA, although denitrification rates appeared to be sufficient for $\mathrm{NO}_{3}{ }^{-}$removal as $\mathrm{NO}_{3}{ }^{-}$concentrations continued to decline in the wall over time (Schipper et al., 2005). The only period of time that $\mathrm{NO}_{3}{ }^{-}$concentrations were elevated downslope of the wall was when $\mathrm{NO}_{3}{ }^{-}$did not contact sawdust because the water table was below the wall (Schipper et al., 2001). Moorman et al. (2010) found that denitrification potential of the wood chips in the denitrification wall after nine years was still 235-fold higher than the surrounding soils suggesting that the wall was still active in removing $\mathrm{NO}_{3}{ }^{-}$through denitrification.

To date, Robertson et al. (2008) presents the only decadal study of the performance of denitrification walls. This study revisited the wall installed downgradient of a septic tank in Canada after 15 years of use (Robertson and Cherry, 1995). During year 15, groundwater $\mathrm{NO}_{3}{ }^{-}$concentrations were at a background level of $0.2 \mathrm{mg} \mathrm{N} \mathrm{L}^{-1}$ (i.e. no loading was occurring to the tile bed from the septic tank). Although concentrations were low, the wall decreased $\mathrm{NO}_{3}{ }^{-}$concentrations to $<0.01 \mathrm{mg} \mathrm{N} \mathrm{L}^{-1}$ for a removal rate of $4 \mathrm{~g} \mathrm{~N} \mathrm{~m}^{-3} \mathrm{~d}^{-1}$. C was being depleted at a rate of about $1 \%$ per year and substantial C was still available for use as an energy source. A laboratory column test of the wall media showed that denitrification rates remained within $50 \%$ of the rates measured in year 1 . Taking all of the results into consideration, it was concluded that the wall continued to be successful in removing $\mathrm{NO}_{3}{ }^{-}$from groundwater after 15 years with the capability of continuing to work into the future.

Since Robertson et al. (2008) presents the only decadal study on denitrification walls, long-term studies of denitrification wall performance remain lacking. More 
information on sustainability is needed including bioreactors utilizing different $\mathrm{C}$ media and bioreactors installed in different climates, soils, and groundwater systems. Little is known about the sustainability of denitrification walls, in particular, how long it takes the organic $\mathrm{C}$ material to degrade and no longer be useful to denitrifiers. As of yet, no denitrification walls have failed with time and so research needs to continue to be done on existing walls to determine longevity. Longevity is important because it means that the wall does not need to be replenished with $\mathrm{C}$ (i.e. the costs are low). Not only are bioreactors low-maintenance, but installation costs are low (approximately NZ $\$ 4000$ or NZ\$3.20 - NZ $\$ 20.00$ per kg N removed) (Schipper et al., 2010a). The research presented in this thesis provides a decadal study on the denitrification wall in New Zealand; the data shows how well the wall is operating in terms of $\mathrm{NO}_{3}{ }^{-}$removal 14 years after construction. 


\section{Chapter 3 Long Term Nitrate Removal in a Denitrification Wall}

\subsection{Abstract}

Denitrification walls are a low-cost approach for removing excess nitrate $\left(\mathrm{NO}_{3}^{-}\right)$from shallow groundwater. Denitrification walls need to be maintenance-free for a number of years to remain cost effective, but little is known about the longevity of these walls. In this study, a denitrification wall constructed on a New Zealand dairy farm in 1996 was monitored to determine $\mathrm{NO}_{3}{ }^{-}$removal by the wall 14 years after installation. After 14 years, the denitrification wall removed $92 \%$ of $\mathrm{NO}_{3}{ }^{-}$input, which ranged from 2.2 to $3.7 \mathrm{mg} \mathrm{N} \mathrm{L}^{-1}$. The $\mathrm{NO}_{3}{ }^{-}$input to the wall had decreased since first constructed, which was attributed to a change in upslope irrigation practices on the farm. Denitrifying enzyme activity (DEA) remained high after 14 years and the wall remained $\mathrm{NO}_{3}{ }^{-}$limited. However, total $\mathrm{C}$ and microbial biomass $\mathrm{C}$ in the wall had decreased by approximately half, while available $\mathrm{C}$ remained relatively constant since year 2 . By applying a first order decay curve, it was determined that total $\mathrm{C}$ in the denitrification wall would not be depleted for 66 years, but it is unclear at what amount of total $\mathrm{C}$ that denitrification would become limited. This long-term study suggested that denitrification walls are cost effective solutions for remediating groundwater $\mathrm{NO}_{3}$ - pollution, as they can be effective for a number of years without any maintenance.

\subsection{Introduction}

Nitrogen $(\mathrm{N})$ is necessary for all life as the primary constituent of nucleotides and proteins (Robertson and Vitousek, 2009). However, more than $99 \%$ of $\mathrm{N}$ on earth is dinitrogen gas $\left(\mathrm{N}_{2}\right)$, which is unavailable to more than $99 \%$ of organisms (Galloway et al., 2003), thereby limiting autotrophic production and affecting ecosystem structure (Robertson and Vitousek, 2009). The need to overcome N limitation in agricultural food production to meet the demands of growing global population has led to increased cultivation of $\mathrm{N}$ fixing plants and development of the Haber-Bosch 
process, which converts $\mathrm{N}_{2}$ to ammonia $\left(\mathrm{NH}_{3}\right)$, the main fertilizer for agricultural systems (Galloway et al., 2003; Seitzinger et al., 2006).

While there are significant benefits of increased production with increased $\mathrm{N}$ inputs, excess $\mathrm{N}$ from agricultural systems enters groundwater and surface waters, and eventually flows to downstream water bodies. Excess $\mathrm{N}$ in the aquatic environment has led to many environmental problems including acidification of freshwater bodies, eutrophication and associated hypoxic zones, adverse health effects for humans and aquatic organisms, and $\mathrm{N}_{2} \mathrm{O}$ production, a greenhouse gas (Camargo and Alonso, 2006). It is important to remediate $\mathrm{N}$ at the source in order to avoid multiple adverse impacts as $\mathrm{N}$ travels to downstream water bodies (Galloway et al., 2003).

Denitrification is the process by which nitrate $\left(\mathrm{NO}_{3}{ }^{-}\right)$is reduced by microbes to the inert $\mathrm{N}_{2}$ gas (Seitzinger et al., 2006). It is the primary removal mechanism of $\mathrm{N}$ from ecosystems (with the exception in some cases of anammox; Burgin and Hamilton, 2007), and therefore is extremely important in terms of maintaining water quality. All other transformation processes keep reactive $\mathrm{N}$ (biologically active $\mathrm{N}$ species) within the terrestrial or aquatic system (Myrold, 2004). The primary controls on denitrification are availability of $\mathrm{NO}_{3}{ }^{-}$and labile $\mathrm{C}$ to act as an energy source, and an absence of oxygen $\left(\mathrm{O}_{2}\right)$ (Tiedje, 1988; Seitzinger et al., 2006). Denitrification tends to be constrained in most modern agricultural systems because agricultural practices are aimed at keeping the root zone aerobic, which indirectly reduces denitrification (Seitzinger et al., 2006). The result can be high levels of $\mathrm{NO}_{3}{ }^{-}$leaching into groundwater and drainage waters, making approaches for enhancing denitrification in agricultural groundwater and drainage waters critical.

One approach for promoting denitrification in groundwater is the installation of denitrification walls (Robertson and Cherry, 1995; Schipper and Vojvodic-Vukovic, 1998; Jaynes et al., 2008). A denitrification wall is constructed by mixing an organic $\mathrm{C}$ source into the soil below the water table in order to intercept groundwater flow (Robertson and Cherry, 1995; Schipper and Vojvodic-Vukovic, 1998). Denitrification walls can be $100 \%$ woodchips (Jaynes et al., 2008), or sawdust mixed 
with soil or sand (Robertson and Cherry, 1995; Schipper and Vojvodic-Vukovic, 1998). These walls are designed to sustain high hydraulic conductivities so that a substantial amount of groundwater flows through the wall and avoids re-routing of groundwater below the wall (Schipper et al., 2004; 2010). Nitrate removal rates supported by denitrification walls generally range from 0.014 to $3.6 \mathrm{~g} \mathrm{~N} \mathrm{~m}^{-3} \mathrm{~d}^{-1}$ (Schipper et al., 2010).

The continued supply of $\mathrm{C}$ to denitrifiers and the maintenance of elevated hydraulic conductivity are the two factors that will affect longevity of denitrification walls (Schipper et al., 2010). No denitrification walls have yet failed due to $\mathrm{C}$ depletion, because $\mathrm{C}$ in denitrification walls appears to decay slowly (Schipper and VojvodicVukovic, 2001; Moorman et al., 2010). However, the sustainability of denitrification walls is poorly understood. Using a stoichiometric approach, it was estimated that a $20 \%$ sawdust denitrification wall near a single-family septic system had enough C available to support 200 years of denitrification, assuming $100 \%$ of $\mathrm{C}$ would be used by denitrifiers (Robertson and Cherry, 1995). One problem with estimating C loss based on stoichiometric equations, such as this, is that they do not take into account the degradation of $\mathrm{C}$ when $\mathrm{O}_{2}$ is present due to water table fluctuations resulting in aerobic degradation of C (Schipper and Vojvodic-Vukovic, 2001). Periodic exposure to aerobic conditions could greatly reduce the longevity of $\mathrm{NO}_{3}{ }^{-}$removal in denitrification walls and could increase $\mathrm{N}_{2} \mathrm{O}$ emissions (Moorman et al., 2010).

Denitrification walls have been shown to maintain high levels of $\mathrm{NO}_{3}{ }^{-}$removal for at least 7 years (Robertson et al., 2000; Schipper et al., 2005), while Moorman et al. (2010) showed that a denitrification wall constructed in central Iowa, USA (Jaynes et al., 2008) sustained $\mathrm{NO}_{3}{ }^{-}$removal for 9 years. The only decadal study of $\mathrm{NO}_{3}{ }^{-}$ removal in a denitrification wall was performed in Canada, which showed continued effectiveness in $\mathrm{NO}_{3}{ }^{-}$removal after 15 years (Robertson et al., 2008). This study used laboratory column tests of the 15 year old wall material rather than direct field sampling of changes in groundwater $\mathrm{NO}_{3}{ }^{-}$concentrations. Therefore, long-term field studies remain sparse for establishing long-term effectiveness of denitrification walls. 
The objective of this study was to determine whether a denitrification wall installed in 1996 in New Zealand still removed $\mathrm{NO}_{3}{ }^{-}$from groundwater 14 years after

installation. We measured groundwater $\mathrm{NO}_{3}{ }^{-}$concentrations upslope, within the wall, and downslope of the wall. Denitrifying enzyme activity was also measured to determine potential $\mathrm{NO}_{3}{ }^{-}$removal within the wall. We also measured total and available $\mathrm{C}$, and microbial biomass $\mathrm{C}$ in the wall to further characterize $\mathrm{C}$ availability in the wall. We compared these data with previous publications (Schipper and Vojvodic-Vukovic, 1998; 2001) to evaluate long-term trends in C decline and to develop an estimation of the longevity of the wall.

\subsection{Methods $^{1}$}

\subsubsection{Study Area}

The denitrification wall was installed at the Bardowie farm in Cambridge, North Island, New Zealand in 1996 as originally described by Schipper and VojvodicVukovic (1998). Soils were poorly drained Aquandic Endoaquepts (USDA, 2010) with subsoil texture varying from sandy loam to silty clay (Schipper and VojvodicVukovic, 1998). The denitrification wall was constructed by digging a trench (35 m long, $1.5 \mathrm{~m}$ deep and $1.5 \mathrm{~m}$ wide) parallel to a stream and mixing the excavated soil with $40 \mathrm{~m}^{3}$ of Pinus radiata sawdust (5\% by weight). The background C content of the soil was $0.16 \%$ (Schipper and Vojvodic-Vukovic, 1998). The soil/sawdust mixture was then returned to the trench to create the denitrification wall, where it intercepted shallow groundwater. After installation, the soil surface above the wall was not actively maintained, but as grass started to re-grow, the cows grazed the area when they were in the paddock. Thirty $60 \mathrm{~mm}$ diameter slotted polyvinyl chloride (PVC) pipes were installed (10 upslope of the wall, 10 within the wall, and 10 downslope of the wall) to monitor groundwater $\mathrm{NO}_{3}{ }^{-}$concentrations (Figure 3.1). The denitrification wall was monitored over its first year of installation (Schipper and Vojvodic-Vukovic, 1998), as well as after five years (Schipper and VojvodicVukovic, 2001), and seven years (Schipper et al., 2005).

\footnotetext{
${ }^{1}$ For a detailed methods section, see Appendix A.
} 
A.

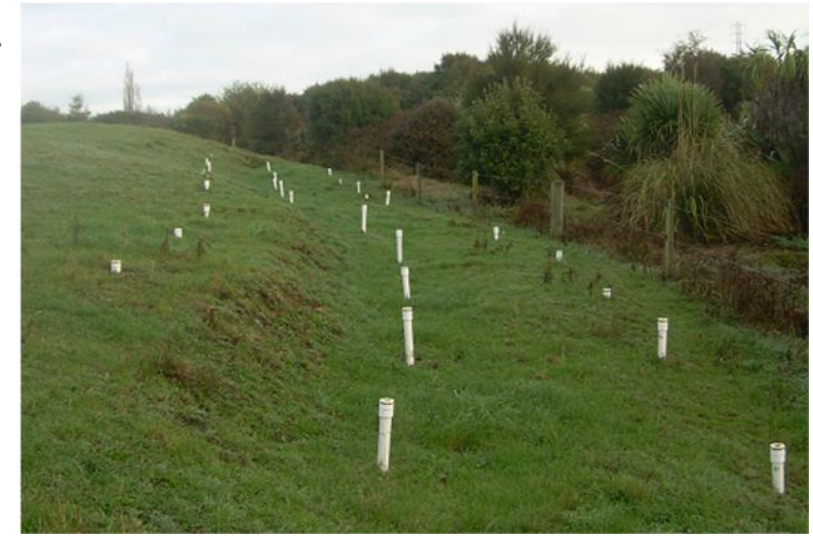

B.

- Groundwater wells

Denitrification wall

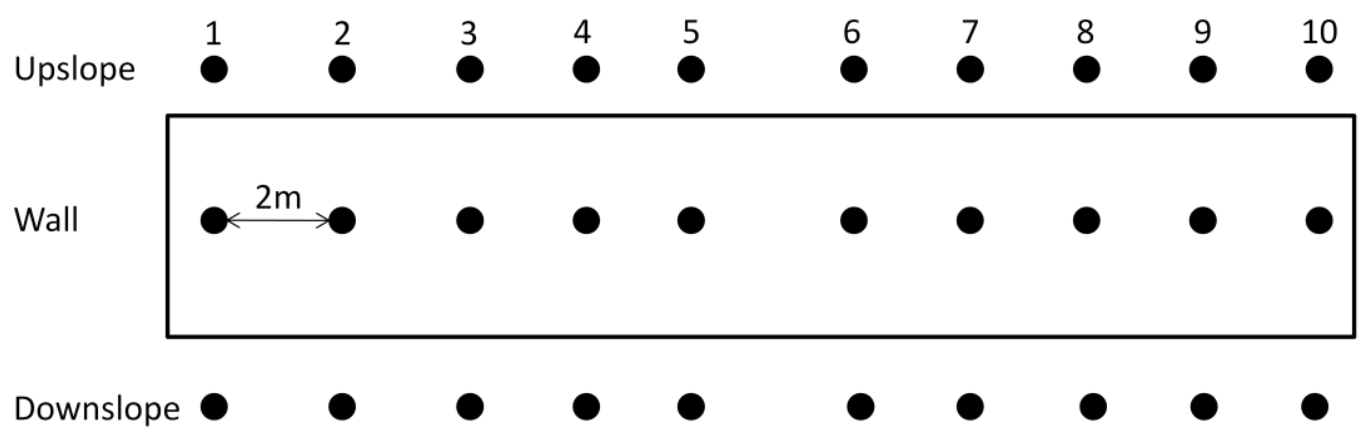

Figure 3.1 A. Photo of the New Zealand denitrification wall taken from the side. The set of wells to the left are the upslope wells, the wells in the middle are within the wall, and the wells to the right are downslope of the wall. $B$. A diagram showing the layout of the groundwater wells in association with the denitrification wall.

The mean annual rainfall for the area from $1971-2000$ was $1190 \mathrm{~mm}$ and mean annual temperature was $13.7^{\circ} \mathrm{C}$ (NIWA; http://www.niwa.co.nz). The Hautapu dairy factory has been spray-irrigating the Bardowie farm with effluent from the factory through a fixed sprinkler system for about 32 years (Sparling et al., 2001). The average $\mathrm{N}$ loading on the farm in 2009 was $400 \mathrm{~kg} \mathrm{~N} \mathrm{ha}^{-1} \mathrm{yr}^{-1}$ (Paul Cooke, Irrigation Team Leader Hautapu Dairy Factory, personal communication). The effluent was applied at a rate of $<5 \mathrm{~mm} \mathrm{hr}^{-1}$, with a maximum of $25 \mathrm{~mm} \mathrm{day}^{-1}$; the effluent was applied up to 4 consecutive days with a subsequent 16 day irrigation-free period (Cooke, personal communication). 


\subsubsection{Soil and Water Sampling}

The denitrification wall was sampled after a dry summer (December - March 2010) when the water table had been below the wall for a few months. In June, the water table rose rapidly and first sampling of the wall was taken within a few days of when water in the groundwater wells was sufficiently high enough to sample. Soil and groundwater samples, as well as soil temperature at $1 \mathrm{~m}$ depth, were taken 15 June, 20 July, 18 August, and 23 August 2010 with additional groundwater samples taken on 30 August (Table 3-1). On each date, six soil samples were taken at approximately $1 \mathrm{~m}$ within the wall using a Dutch auger $(6 \mathrm{~cm}$ diameter) and then stored at $4^{\circ} \mathrm{C}$ until analyzed, within 3 days. Groundwater was collected from the wells and stored on ice until returning to the laboratory where they were immediately filtered and then frozen until analyzed.

Table 3-1 Depth to water table and soil temperature on dates of sampling. Depth to water table is an average of 10 measurements. *n.m. means not measured.

\begin{tabular}{llll}
\hline Sampling date & $\begin{array}{l}\text { Time since } \\
\text { construction (days) }\end{array}$ & $\begin{array}{l}\text { Depth to watertable } \\
\text { from soil surface }(\mathrm{cm})\end{array}$ & $\begin{array}{l}\text { Soil temperature at 1 } \\
\text { m depth }\left({ }^{\circ} \mathrm{C}\right)\end{array}$ \\
\hline 15 June 2010 & 5245 & n.m. & 14 \\
20 July 2010 & 5280 & 55 & 11 \\
18 August 2010 & 5299 & 21 & n.m. \\
23 August 2010 & 5304 & 22 & n.m. \\
30 August 2010 & 5311 & 54 & n.m. \\
\hline
\end{tabular}

Additional depth profile sampling within the wall was undertaken on 23 August 2010 to determine if there had been greater changes in soil biochemistry in the shallow soils compared to deeper soils due to the fluctuating water table. Six sites within the wall were sampled down to a depth of $120 \mathrm{~cm}$ at intervals of $20 \mathrm{~cm}$ to give a total of 6 samples per site. The soil samples were placed in plastic Ziploc bags and stored at $4^{\circ} \mathrm{C}$ in the laboratory until analysis within 7 days.

\subsubsection{Soil and Water Analysis}

Denitrifying enzyme activity (DEA) in the soil samples were measured using a modified method from Tiedje et al. (1989) by placing fresh soil (35 g) and a $70 \mathrm{~mL}$ 
solution containing both $0.2 \mathrm{~g} \mathrm{~L}^{-1}$ glucose and $0.1 \mathrm{~g} \mathrm{~L}^{-1} \mathrm{KNO}_{3}{ }^{-}$into a glass jar. To determine whether $\mathrm{NO}_{3}{ }^{-}, \mathrm{C}$, or both limited the rate of denitrification, each soil sample was partitioned into an additional 3 jars: one with a $70 \mathrm{~mL}$ solution containing $0.2 \mathrm{~g} \mathrm{~L}^{-1}$ glucose; one with a $70 \mathrm{~mL}$ solution containing $0.1 \mathrm{~g} \mathrm{~L}^{-1} \mathrm{KNO}_{3}{ }^{-}$; and one control (no additions). All treatments included $0.12 \mathrm{~g} \mathrm{~L}^{-1}$ chloramphenicol to prevent de novo enzyme synthesis. The jars were flushed with $\mathrm{N}_{2}$ gas and $20 \mathrm{~mL}$ of acetylene (7.7\% headspace acetylene) was added, then the jars were incubated at $28^{\circ} \mathrm{C}$ and shaken at $200 \mathrm{rpm}$. Headspace gas samples $(5 \mathrm{~mL})$ were taken from each jar at 15 , 30,45 , and 75 minutes and analyzed for $\mathrm{N}_{2} \mathrm{O}$ using a gas chromatograph (Varian CP3800; Santa Clara, California) equipped with an electron capture detector.

Microbial biomass $\mathrm{C}$ content of the soil samples was measured by chloroform $\left(\mathrm{CHCl}_{3}\right)$ fumigation technique adapted from Vance et al. (1987). Fresh soil (50 g) was extracted with $0.5 \mathrm{M} \mathrm{K}_{2} \mathrm{SO}_{4}(200 \mathrm{~mL})$ and then centrifuged, filtered, and frozen until analysis. The extractants were analyzed for total organic C (TOC) using a Lachat TOC analyzer (model IL550 TOC; Loveland, Colorado). Additionally, fresh soil (50 g) was placed into a desiccator with a beaker containing $25 \mathrm{~mL}$ of purified $\mathrm{CHCl}_{3}$. The desiccator was evacuated using a vacuum until the $\mathrm{CHCl}_{3}$ boiled for 2 minutes, and then incubated at $25^{\circ} \mathrm{C}$ for 24 hours in the dark. After 24 hours, the dessicator was evacuated using the vacuum to remove all traces of $\mathrm{CHCl}_{3}$ vapour from the soils. The fumigated soils were then extracted as described above and the filtered extracts were frozen until analysis for TOC. Microbial biomass $\mathrm{C}$ was calculated using a $\mathrm{k}_{\mathrm{EC}}$ factor of 0.41 applied to the difference in TOC extracted from $\mathrm{CHCl}_{3}$ fumigated and unfumigated soils (Sparling et al., 2001).

Available $\mathrm{C}$ content of the soil samples was measured using a modified version of Sparling and Zhu (1993) by placing fresh soil (25 g) into $1 \mathrm{~L}$ glass jars and incubating at $25^{\circ} \mathrm{C}$ for 7 days. After 7 days, $1 \mathrm{~mL}$ gas samples were taken from the headspace and analyzed for $\mathrm{CO}_{2}$ concentration on a LI-COR $\mathrm{CO}_{2} / \mathrm{H}_{2} \mathrm{O}$ analyzer (Model LI6262; Lincoln, Nebraska). 
Total $\mathrm{C}$ content of the soil samples (dried at $60^{\circ} \mathrm{C}$ overnight and then ground on a Retsch MM2000 (Haan, Germany) mixer mill grinder) was measured on a LECO TruSpec CN Carbon/Nitrogen Determinator (St. Joseph, Michigan).

Groundwater $\mathrm{NO}_{3}{ }^{-}$concentrations were analyzed on a Lachat Quikchem FIA 8000 series using a Lachat XYZ Autosampler (ASX 500 series; Loveland, Colorado) after centrifugation at $3000 \mathrm{rpm}$ for 10 minutes and filtration through $0.45 \mu \mathrm{m}$ Advantec filter paper.

Soil water content was measured gravimetrically after drying at $105^{\circ} \mathrm{C}$ to constant weight.

\subsubsection{Loss of Carbon over Time}

The relationship between available $\mathrm{C}$ and DEA was used to estimate the longevity of available $\mathrm{C}$ in the denitrification wall needed to support detectable DEA rates (Burford and Bremner, 1975). Thirty-two soil samples were taken with a Dutch auger within the denitrification wall, 16 at $0.5 \mathrm{~m}$ and 16 at $1 \mathrm{~m}$ depth. Half of the soil samples (half at $0.5 \mathrm{~m}$ depth and half at $1 \mathrm{~m}$ depth) were flushed with $\mathrm{N}_{2}$ gas to create anaerobic conditions, and the other half were incubated aerobically in $350 \mathrm{~mL}$ glass jars at $25^{\circ} \mathrm{C}$ for 7 days. After 7 days, available $\mathrm{C}$ and DEA were measured following the methods described above. A linear regression was performed on the data to determine if the relationship between DEA and available $\mathrm{C}$ was significant $(\mathrm{p}<0.05)$. This relationship was then used to determine the minimum available $\mathrm{C}$ required to support detectable DEA (c.f. Schipper et al., 1994). A decay curve was then fitted to the available $\mathrm{C}$ data, collected over the last 14 years, and used to predict the time at which available $\mathrm{C}$ would fall below the minimum available $\mathrm{C}$ needed to support DEA. As a second approach, a first order decay curve was fitted to the total $\mathrm{C}$ data to predict when the total $\mathrm{C}$ within the wall would be depleted.

\subsubsection{Statistical Analysis}

To determine whether $\mathrm{C}, \mathrm{NO}_{3}{ }^{-}$, or both was limiting in the denitrification wall, a twoway ANOVA was performed on the DEA data with $\mathrm{NO}_{3}{ }^{-}$and $\mathrm{C}$ as the main factors. 
A significant result $(\mathrm{p}<0.05)$ for $\mathrm{NO}_{3}{ }^{-}$indicated $\mathrm{NO}_{3}{ }^{-}$limitation, while a significant result $(\mathrm{p}<0.05)$ for $\mathrm{C}$ indicated $\mathrm{C}$ limitation. If the interaction between $\mathrm{NO}_{3}{ }^{-}$and $\mathrm{C}$ was significant $(\mathrm{p}<0.05)$, then the system was considered co-limited by $\mathrm{NO}_{3}{ }^{-}$and $\mathrm{C}$ (Tank and Dodds, 2003). Two-sample t-tests assuming unequal variances were used to compare data from year 1 to year 14 to determine whether the various parameters measured had significantly decreased over time; $\mathrm{p}<0.05$ was considered significant.

\subsection{Results}

\subsubsection{Nitrate Removal and Biochemistry}

Higher $\mathrm{NO}_{3}{ }^{-}$concentrations entered wells $6-10$ compared to wells $1-5$, likely because groundwater entering into wells $1-5$ moved slowly while the hydraulic gradient around wells 6 - 10 was steeper and subsequently groundwater flow velocity was greater (Figure 3.2; Schipper and Vojvodic-Vukovic, 2000). There was a spike in $\mathrm{NO}_{3}{ }^{-}$concentrations both within and downslope of the wall in well 10 (at the very edge of the wall) which was most likely caused by some groundwater flowing around the side of the denitrification wall rather than through the wall. Fourteen years after installation, the denitrification wall continued to remove $\mathrm{NO}_{3}{ }^{-}$from groundwater

(Figure 3.3). Groundwater $\mathrm{NO}_{3}{ }^{-}$input averaged $2.6 \mathrm{mg} \mathrm{N} \mathrm{L}^{-1}$ (standard error (SE) of $0.4)$ in year 14 , which was significantly less $(\mathrm{p}=0.01)$ than an average of $9 \mathrm{mg} \mathrm{N} \mathrm{L}^{-1}$ (SE of 0.7) through the first 5 years after the wall was installed. Groundwater within the wall had $\mathrm{a} \mathrm{NO}_{3}{ }^{-}$concentration of $0.2 \mathrm{mg} \mathrm{N} \mathrm{L}^{-1}$ ( $\mathrm{SE}$ of 0.04 ) in year 14 corresponding to $92 \%$ removal, similar to the $91 \%$ removal measured over the first 5 years (Figure 3.3). 


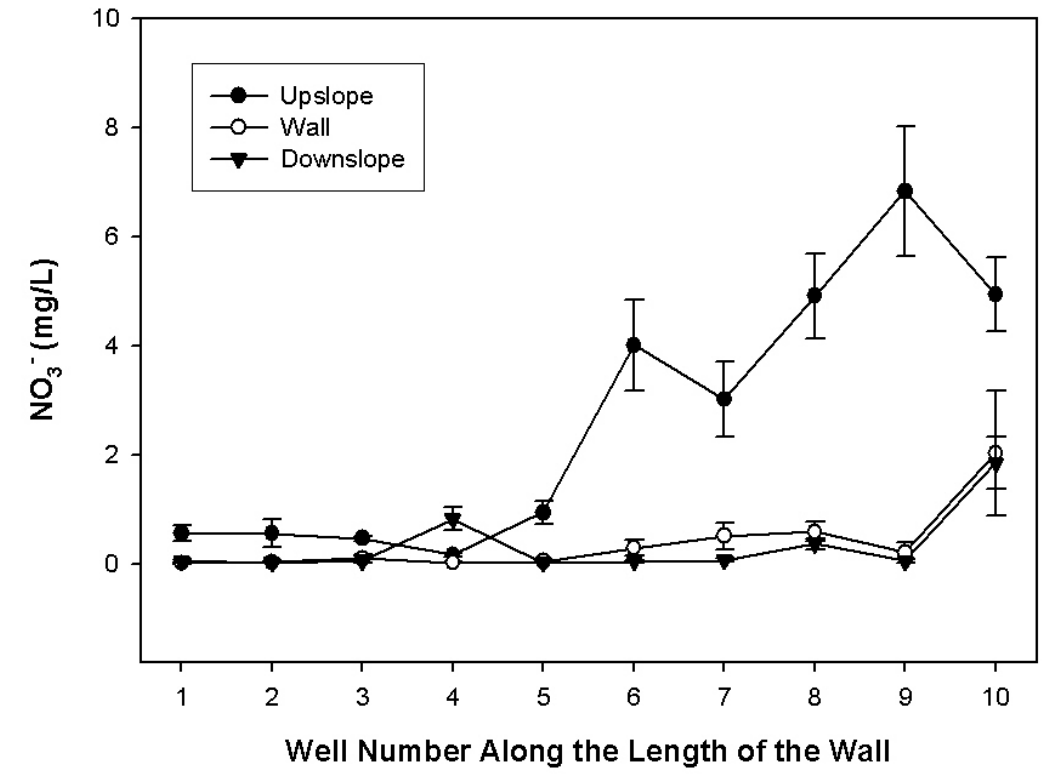

Figure 3.2 Nitrate concentrations (averaged through time) upslope, within, and downslope of the wall over a two month period in $2010(n=4$ and data are presented $+/-1 \mathrm{SE}$ ). Samples were taken on 20 July, 18 August, 23 August, and 30 August. The wells are arranged along the length of the wall at approximately $2 \mathrm{~m}$ intervals with the first and last well approximately $1 \mathrm{~m}$ from the edge of the denitrification wall.



Figure 3.3 Nitrate input to the denitrification wall and nitrate within the wall since installation in 1996 ( $n=10$ and data presented are +/- $1 \mathrm{SE}$ ). Note that there was a period of 9 years where no samples were taken and that the time scale is 30 days after the break in the $x$-axis. 
Groundwater $\mathrm{NO}_{3}{ }^{-}$input concentrations were extremely low in June $\left(0.84 \mathrm{mg} \mathrm{N} \mathrm{L}^{-1}\right)$ while the $\mathrm{NO}_{3}{ }^{-}$concentration in the wall was relatively high $\left(1.86 \mathrm{mg} \mathrm{N} \mathrm{L}^{-1}\right)$; this was likely due to the water table rising rapidly in the few weeks prior to measurement. By July, $\mathrm{NO}_{3}{ }^{-}$concentrations within the wall had decreased to $0.1 \mathrm{mg} \mathrm{N} \mathrm{L}^{-1}$ indicating that the wall had recovered quickly from the initial flush and $\mathrm{NO}_{3}{ }^{-}$removal had recommenced. $\mathrm{NO}_{3}{ }^{-}$removal continued in all subsequent sampling periods.

Over 3 months of measurement in year 14, DEA averaged $695 \mathrm{ng} \mathrm{N} \mathrm{g}^{-1} \mathrm{hr}^{-1}$ (SE of 82; excluding June), which was similar to year 1 (average of $740 \mathrm{ng} \mathrm{N} \mathrm{g}^{-1} \mathrm{hr}^{-1}$, SE of 72). The DEA measurement in June was high at $3269 \mathrm{ng} \mathrm{N} \mathrm{g}^{-1} \mathrm{hr}^{-1}$ and may have been due to initially rapid inputs of $\mathrm{NO}_{3}{ }^{-}$following heavy rains after a long period where the denitrifiers had been dormant during the unusually dry summer. The denitrification wall remained $\mathrm{NO}_{3}{ }^{-}$limited after 14 years (two-way ANOVA, $\mathrm{p}<$ 0.05; Table 3-2). DEA in both years 1 and 14 were greater than the values reported in years 2 - 5 (Schipper and Vojvodic-Vukovic, 2001), which were approximately $10 \%$ of what was measured in years 1 and 14 (Figure 3.4).

Table 3-2 ANOVA output for the denitrifying enzyme activity (DEA) amendment experiment. Potential denitrification rates were measured on soil samples that were amended with (i) nitrate (N) only, (ii) carbon (C) only, or (iii) both $N+C$. Values with $p<0.05$ are considered significant. $\mathrm{N}+\mathrm{C}$ is the interaction component to determine co-limitation.

\begin{tabular}{lllllllll}
\hline ANOVA & \multicolumn{2}{c}{ 15 June } & \multicolumn{2}{c}{ 20 July } & \multicolumn{2}{c}{18 Aug } & \multicolumn{2}{c}{23 Aug } \\
component & p-level & F & p-level & F & p-level & F & p-level & F \\
\hline N & 0.038 & 5.1 & $<0.01$ & 13.9 & $<0.01$ & 17.5 & $<0.01$ & 10.4 \\
C & 0.65 & 0.2 & 0.64 & 0.2 & 0.88 & 0.02 & $<0.01$ & 9.0 \\
N + C & 0.68 & 0.2 & 0.65 & 0.2 & 0.89 & 0.02 & 0.25 & 1.3 \\
\hline
\end{tabular}




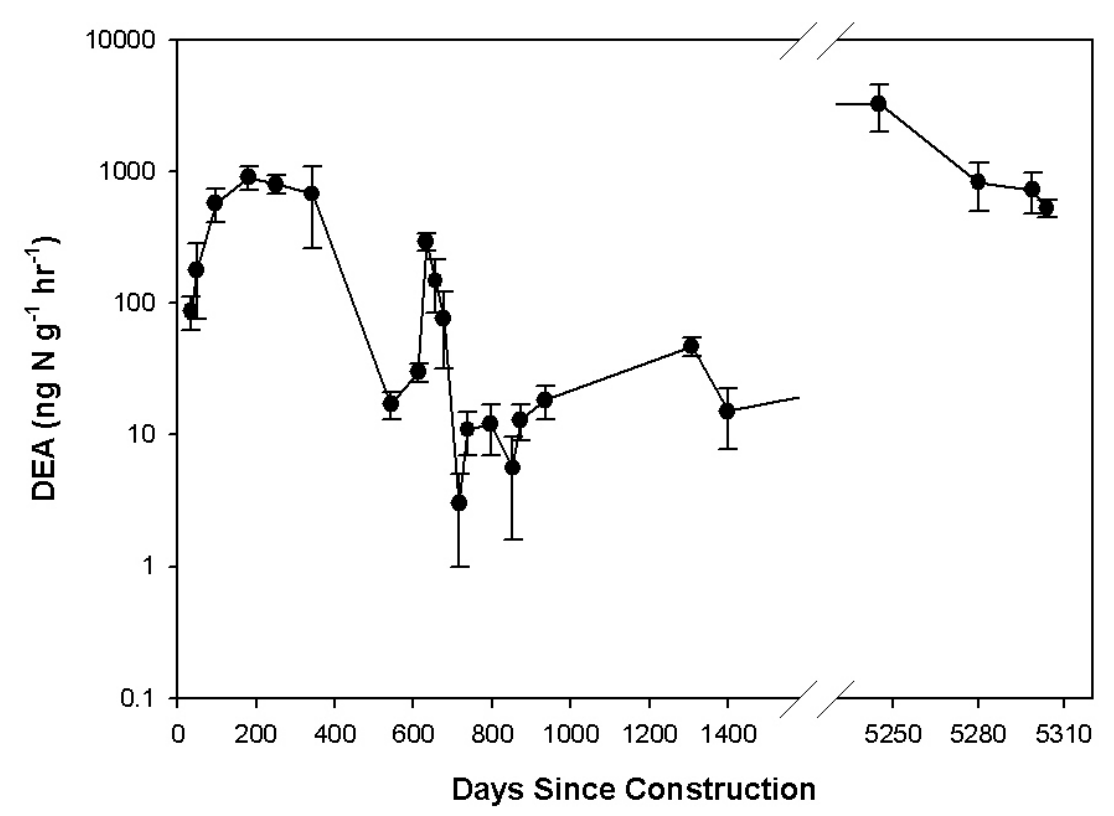

Figure 3.4 Denitrifying enzyme activity (DEA) rates over time in the denitrification wall since installation in 1996. Note that there was a period of 9 years where no samples were taken and that the time scale is 30 days after the break in the $x$-axis. DEA data are presented logtransformed ( $n=6$ and data presented are $+/-1 \mathrm{SE}$ ).

Total C had significantly decreased, by about half, from an average of $4.7 \%$ (SE of 0.31 ) in the first 5 years to an average of $2.2 \%$ (SE of $0.13 ; \mathrm{p}<0.01$ ) in year 14 (Figure 3.5). Similarly, microbial biomass $\mathrm{C}$ had significantly decreased by approximately half since the wall installation from an average of $445 \mu \mathrm{g} \mathrm{C} \mathrm{g}^{-1}$ soil (SE of 27) over the first 5 years to an average of $260 \mu \mathrm{g} \mathrm{C} \mathrm{g}^{-1}$ soil (SE of 42; $\mathrm{p}<$ 0.01) in year 14 (Figure 3.5). However, the microbial quotient, which expresses microbial biomass $\mathrm{C}$ as a percentage of total C (Haynes, 1999), remained relatively constant at $0.8 \%$ over the first 5 years of operation and $1.2 \%$ during year 14 .

Available $\mathrm{C}$ within the wall significantly decreased between the first and second year of operation (from $5.4 \mu \mathrm{g} \mathrm{C} \mathrm{g}^{-1} \mathrm{hr}^{-1}$ with a SE of 0.49 to $2.3 \mu \mathrm{g} \mathrm{C} \mathrm{g}^{-1} \mathrm{hr}^{-1}$ with a SE of $0.21 ; \mathrm{p}=0.04$ ), but has not significantly declined since (with an average of $1.9 \mu \mathrm{g} \mathrm{C}$ $\mathrm{g}^{-1} \mathrm{hr}^{-1}$ and a SE of 0.21 in year 14; Figure 3.5). 

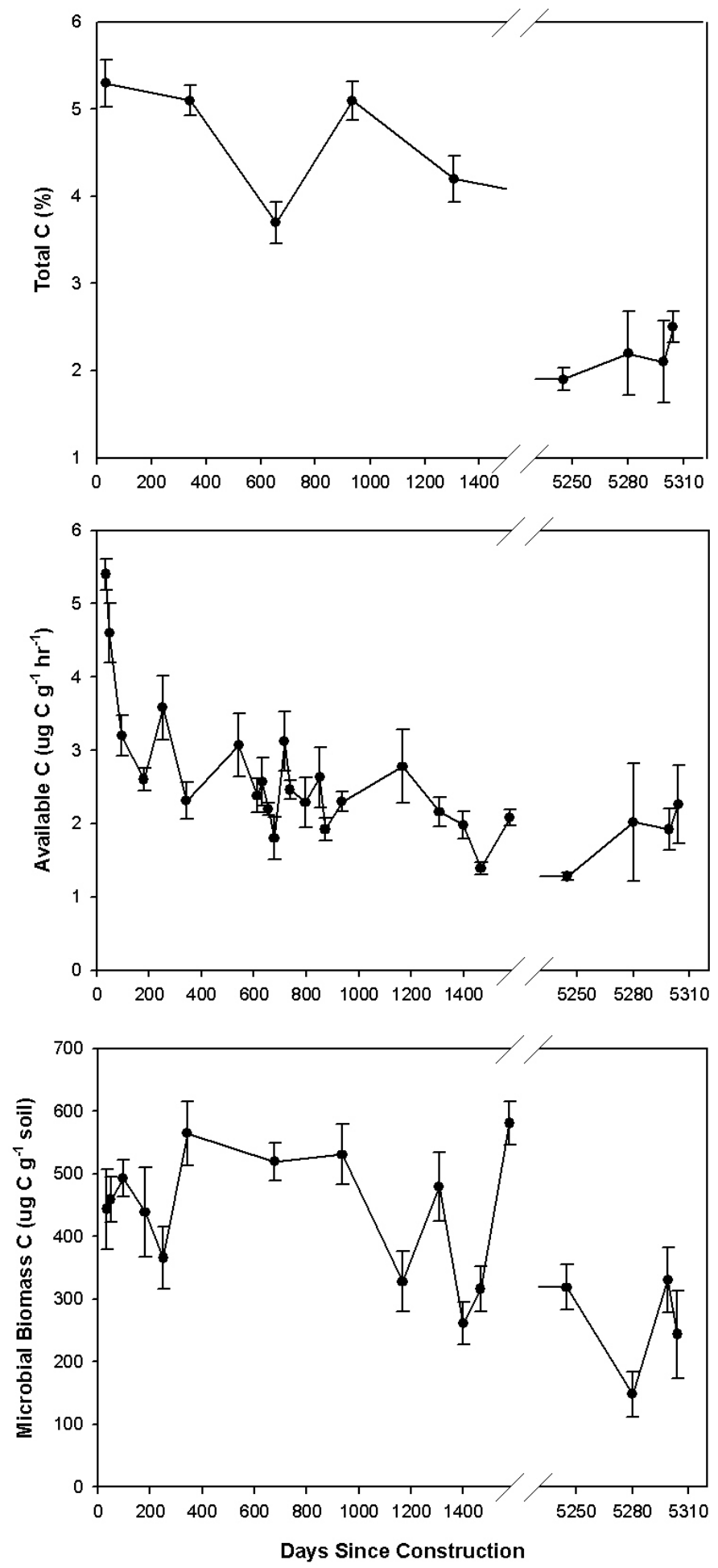

Figure 3.5 Total carbon, available carbon, and microbial biomass carbon over time in the denitrification wall since installation in $1996(n=6$ and data presented are $+/-1$ SE). Note that there was a period of 9 years where no samples were taken and that the time scale is $\mathbf{3 0}$ days after the break in the $x$-axis. 
There was no relationship between available $\mathrm{C}$ measured under anaerobic conditions and DEA (data not shown). However, there was a significant, linear relationship between available $\mathrm{C}$ measured under aerobic conditions and DEA (Figure 3.6; $\mathrm{R}^{2}=$ 0.47; $\mathrm{p}<0.01)$. The linear regression between available $\mathrm{C}$ and DEA indicated that DEA would be below detection at an available $\mathrm{C}$ of $0.07 \mu \mathrm{g} \mathrm{C} \mathrm{g}^{-1} \mathrm{~h}^{-1}$ (Figure 3.6).

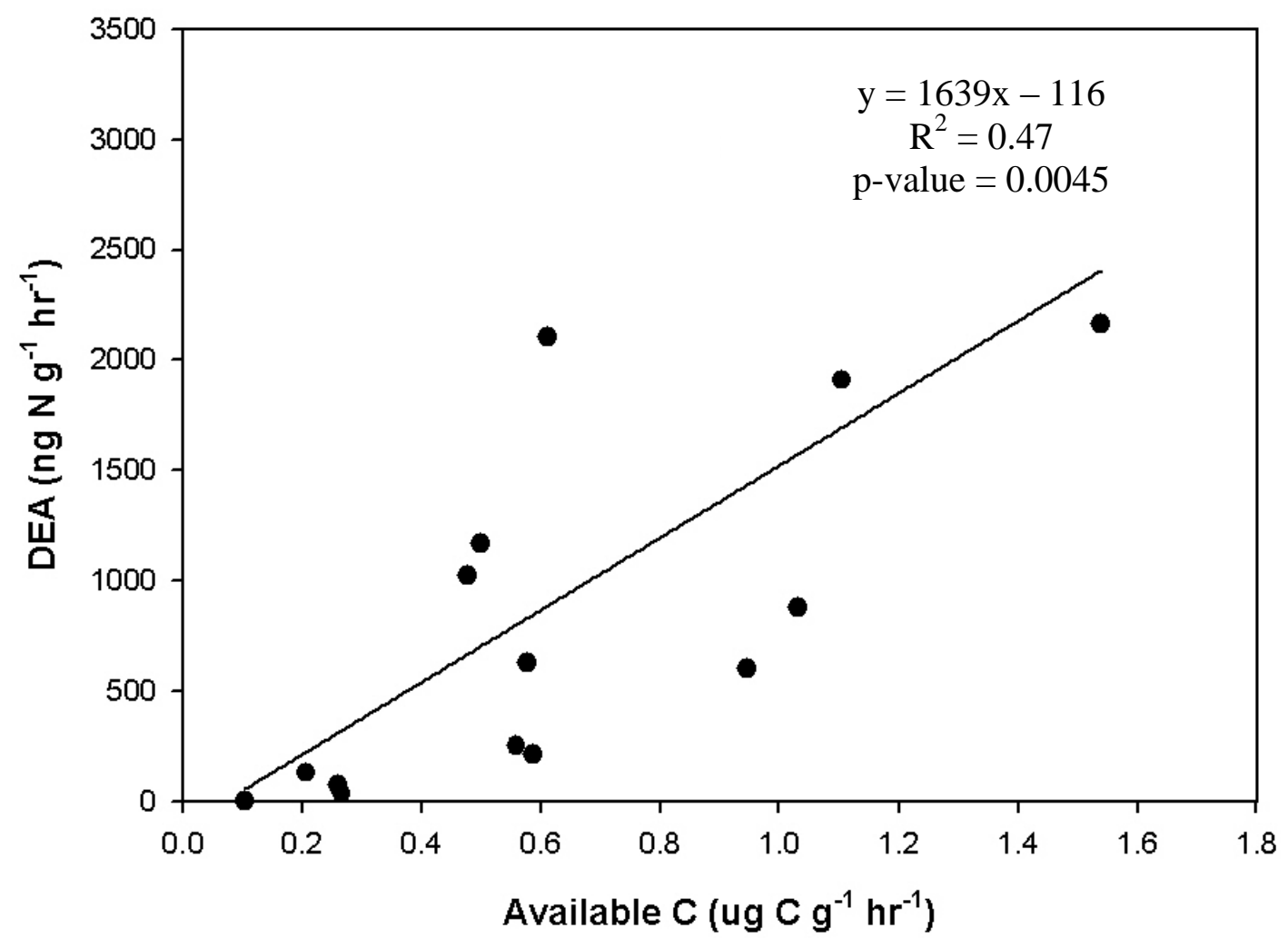

Figure 3.6 Increases in denitrifying enzyme activity (DEA) compared with increases in available $\mathrm{C}$ measured under aerobic conditions. Samples were taken at $0.5 \mathrm{~m}$ and $1 \mathrm{~m}$ depth.

\subsubsection{Depth Profiles}

Depth profile sampling was undertaken in order to determine if there were gradients in $\mathrm{C}$ or DEA above and below the water table. Both available $\mathrm{C}$ and total $\mathrm{C}$ were highest at about a depth of $90 \mathrm{~cm}$ at $2.26 \mu \mathrm{g} \mathrm{C} \mathrm{g}^{-1} \mathrm{hr}^{-1}$ and $2.5 \%$, respectively (Figure 3.7). Microbial biomass $C$ declined from the soil surface down to $30 \mathrm{~cm}$, then remained relatively constant down to $70 \mathrm{~cm}$, and then declined to a minimum value of $243 \mu \mathrm{g} \mathrm{C} \mathrm{g}^{-1}$ soil. The microbial quotient ranged between $2 \%$ and $3 \%$ for the first 70 $\mathrm{cm}$ and then declined to around $1 \%$ in the $90-100 \mathrm{~cm}$ range, which was similar to 
that measured at $1 \mathrm{~m}$ depth over the lifetime of the denitrification wall. DEA values peaked at $50 \mathrm{~cm}$ and remained higher than surface soil values until a depth of $110 \mathrm{~cm}$. There was a high degree of variation in DEA throughout the profile, which may have been influenced by variable soil moisture in the 6 replicates for each depth; the average coefficient of variation of DEA for the 6 depths was 0.95 . 


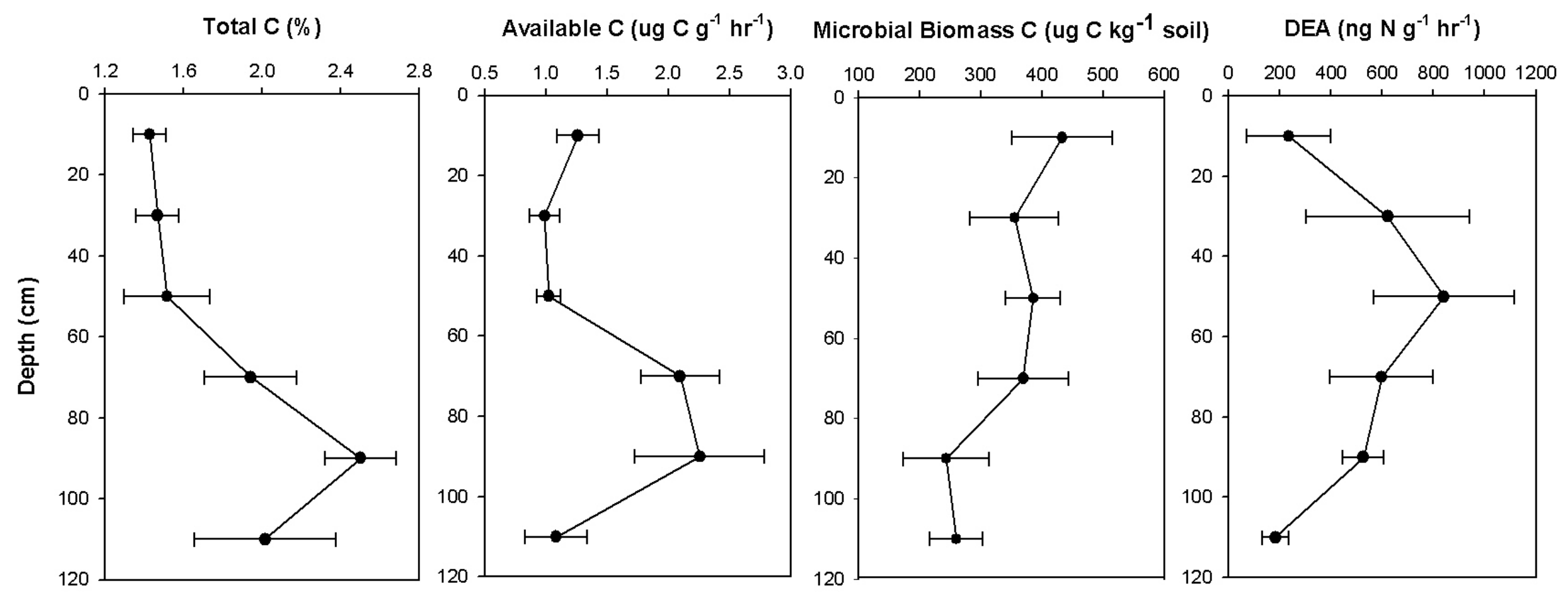

Figure 3.7 Depth profile sampling taken on 23 August 2010 for total carbon, available carbon, microbial biomass carbon, and denitrifying enzyme activity within the denitrification wall $(n=6$ and data presented are $+/-1 \mathrm{SE})$. 


\subsection{Discussion}

\subsubsection{Nitrate Removal and Biochemistry}

After 14 years, the denitrification wall continued to remove a large proportion of groundwater $\mathrm{NO}_{3}{ }^{-}$entering the wall, likely through denitrification (Schipper and Vojvodic-Vukovic, 1998). Two other transformations could result in the removal of $\mathrm{NO}_{3}{ }^{-}$: dissimilatory nitrate reduction to ammonium (DNRA) or biotic immobilization. Previous work on this wall discounted DNRA because ammonium concentrations did not increase in the wall concurrently with decreases in $\mathrm{NO}_{3}{ }^{-}$and changes in total $\mathrm{N}$ within the wall were minor suggesting that immobilization was most likely not a factor (Schipper and Vojvodic-Vukovic, 1998). DEA rates measured in year 14 were similar as measured in year 1 indicating that denitrification was still an important mechanism for $\mathrm{NO}_{3}{ }^{-}$removal. Further, denitrification in the wall remained $\mathrm{NO}_{3}{ }^{-}$ limited indicating that the wall had not been oversupplied with $\mathrm{NO}_{3}{ }^{-}$.

Continued $\mathrm{NO}_{3}{ }^{-}$removal through denitrification in a denitrification wall is dependent on a supply of available C (Schipper et al., 2010). Total C had declined since installation of the wall so that about half of the total $\mathrm{C}$ remained after 14 years. Carbon becomes available for denitrifiers through degradation of the sawdust by other heterotrophic microbes (Tiedje, 1988). It would appear that there was still sufficient $\mathrm{C}$ available in the denitrification wall for denitrifiers because DEA rates had remained high over 14 years and there was no increase in DEA when $\mathrm{C}$ was added (the wall was not $\mathrm{C}$ limited, Table 3-2). In fact, while available $\mathrm{C}$ decreased greatly over the first year of operation, available $\mathrm{C}$ remained relatively steady for the next 13 years (Schipper and Vojvodic-Vukovic, 1998; 2001).

Microbial biomass $\mathrm{C}$ decreased proportionally to total $\mathrm{C}$ as indicated by the steady microbial quotient of approximately $1 \%$ throughout 14 years since the wall was first built. As total $\mathrm{C}$ declined, there would be less $\mathrm{C}$ for microbes to degrade, and consequently the microbial population decreased. Nevertheless, there was still sufficient microbial population and total $\mathrm{C}$ to continue to supply denitrifiers with $\mathrm{C}$ from the decomposition of sawdust. Few studies of denitrification walls have 
measured total $\mathrm{C}$, available $\mathrm{C}$ and microbial biomass $\mathrm{C}$ (but see Moorman et al., 2010); however, the continued supply of available $C$ measured in this study suggests that sawdust was a good $\mathrm{C}$ source to use in a denitrification wall due to its longevity.

\subsubsection{Longevity of Denitrification Walls}

There have been two other studies that have looked at the longevity of denitrification walls (Robertson et al., 2008; Moorman et al., 2010). The denitrification wall in this study remained effective for 14 years, where more than $90 \%$ of $\mathrm{NO}_{3}{ }^{-}$input was removed. Nitrate input ranged from $2-15 \mathrm{mg} \mathrm{N} \mathrm{L}^{-1}$ during the 14 years of measurement. A denitrification wall constructed in Iowa, USA from 100\% woodchips was found to still be effective after 9 years (Moorman et al., 2010). The Iowa denitrification wall achieved around $60 \% \mathrm{NO}_{3}{ }^{-}$removal over the first two years and $50 \%$ thereafter, where $\mathrm{NO}_{3}{ }^{-}$input to the wall averaged $22 \mathrm{mg} \mathrm{N} \mathrm{L}^{-1}$. Similar to the New Zealand denitrification wall, the Iowa denitrification wall was not limited by C (i.e. glucose additions did not stimulate denitrification), suggesting that the wall was $\mathrm{NO}_{3}{ }^{-}$limited. The only other decadal study to date demonstrated that a denitrification wall constructed in Ontario, Canada from 20\% sawdust mixed with soil (Robertson and Cherry, 1995) still removed $\mathrm{NO}_{3}{ }^{-}$after 15 years (Robertson et al., 2008). Input $\mathrm{NO}_{3}{ }^{-}$concentrations in the Canada wall ranged from $<2 \mathrm{mg} \mathrm{N} \mathrm{L}^{-1}$ up to $100 \mathrm{mg} \mathrm{N} \mathrm{L}^{-1}$ over the 15 years of performance and the wall achieved near-complete $\mathrm{NO}_{3}{ }^{-}$removal over time. These three studies suggest that relatively small sawdust additions $(5 \% ; 20 \%)$ are just as sustainable as $100 \%$ woodchip additions, although $\mathrm{NO}_{3}{ }^{-}$input varied between the studies.

There was an apparent difference in $\mathrm{C}$ decomposition with depth in the denitrification wall. C concentrations were highest at $90 \mathrm{~cm}$ depth, where the soils were moist even during the dry summer months, which suggested that $\mathrm{C}$ decayed more slowly at depth most likely due to anaerobic conditions. Further supporting this, available $\mathrm{C}$ at $1 \mathrm{~m}$ depth was greater than at $0.5 \mathrm{~m}$ depth (mean at $0.5 \mathrm{~m}$ was $0.47 \mu \mathrm{g} \mathrm{C} \mathrm{g}^{-1} \mathrm{hr}^{-1}$; mean at $1 \mathrm{~m}$ was $0.82 \mu \mathrm{g} \mathrm{C} \mathrm{g}^{-1} \mathrm{hr}^{-1}$; Z-test $\mathrm{p}<0.01$ ). Similarly, in Iowa, $75 \%$ of $\mathrm{C}$ was decomposed at the $90-100 \mathrm{~cm}$ depth while only $13 \%$ of $\mathrm{C}$ was decomposed at $155-$ $170 \mathrm{~cm}$ depth after 9 years (Moorman et al., 2010). 
The first order decay curve fitted to changes in total $\mathrm{C}$ predicted a half-life of 11.1 years at $90 \mathrm{~cm}$ depth. Similarly, the study on the Iowa denitrification wall estimated that the half-life of $\mathrm{C}$ was 4.6 years at the $90-100 \mathrm{~cm}$ depth, and 36.6 years at the 155 - $170 \mathrm{~cm}$ depth (Moorman et al., 2010). The half-life for the New Zealand denitrification wall was longer than the one predicted by Moorman et al. (2010) at the same depth, suggesting that the Iowa denitrification wall may be subjected to more frequent aerobic conditions as water table varied and higher temperatures more often than the wall in this study.

There has been some evidence that the $\mathrm{C}$ in denitrification walls becomes less effective in removing $\mathrm{NO}_{3}{ }^{-}$over time as the $\mathrm{C}$ degrades (Robertson, 2010), but that does not seem to be the case in this study. We found that DEA rates after 14 years were similar to those measured in year 1 and that the denitrification wall was still removing $92 \%$ of $\mathrm{NO}_{3}{ }^{-}$input. However, DEA measurements in this study and in year 1 were much higher that what was observed in years $2-5$ (Schipper and VojvodicVukovic, 2001). DEA rates may have been so high in year 14 due to the flush of water in June after a long dry period, where the water table was below the wall, so that incomplete aerobic decomposition may have released substantial $\mathrm{C}$ that would be available to denitrifiers. Even though DEA rates were low in years $2-5, \mathrm{NO}_{3}{ }^{-}$ removal remained high (Schipper and Vojvodic-Vukovic, 2001). On the other hand, using laboratory column tests, it was shown that 2-year old and 7-year old wood chip material was $50 \%$ less effective in removing $\mathrm{NO}_{3}{ }^{-}$than fresh woodchips (Robertson, 2010). This would suggest that $\mathrm{NO}_{3}{ }^{-}$removal decreases by half in denitrification walls after the first year under idealized laboratory conditions, which is contrary to what we observed in this study. The difference is probably due to $\mathrm{NO}_{3}{ }^{-}$loading as $\mathrm{NO}_{3}{ }^{-}$remained limited in the New Zealand denitrification wall. As long as there is sufficient $\mathrm{C}$ and a sufficient microbial population to degrade the $\mathrm{C}$ to a usable form, $\mathrm{NO}_{3}{ }^{-}$removal will remain high as the denitrification wall ages.

We found that DEA was correlated to available $\mathrm{C}$ as found by others (Tiedje, 1988; Schipper et al., 1994), however, this relationship was not useful for predicting when 
$\mathrm{NO}_{3}{ }^{-}$removal in a denitrification wall will become limited. Upon applying a decay curve to the changes in available $\mathrm{C}$ data through time, it was apparent that available $\mathrm{C}$ had plateaued and was not be useful in predicting $\mathrm{C}$ decline into the future. A first order $\mathrm{C}$ decay curve was fitted to the total $\mathrm{C}$ data from the previous 14 years (Schipper and Vojvodic-Vukovic, 1998; 2001) where total C was predicted to $0.1 \%$ of soil in year 66 with a prediction interval of $(0.04 \%, 0.264 \%)\left(\mathrm{R}^{2}=0.92 ; \mathrm{p}<0.05\right)$. Although the fitted $\mathrm{C}$ decay curve gives an estimate on how long $\mathrm{C}$ will remain in the wall, it is unclear at what level of total $\mathrm{C}$ denitrification would become limited in the denitrification wall.

\subsection{Conclusions}

A denitrification wall installed 14 years ago was found to still support $\mathrm{NO}_{3}{ }^{-}$removal in accordance with Moorman et al. (2010) and Robertson et al. (2008) which found that denitrification walls were still effective after 9 years and 15 years respectively. $\mathrm{NO}_{3}{ }^{-}$entered the wall at a concentration of $2.6 \mathrm{mg} \mathrm{N} \mathrm{L}^{-1}$ and declined to $0.2 \mathrm{mg} \mathrm{N} \mathrm{L}^{-1}$ within the wall, indicating that the wall was still effective in $\mathrm{NO}_{3}{ }^{-}$removal. Denitrification rates (using DEA as an index) were found to be nearly as high as they were when the denitrification wall was initially installed. Total $\mathrm{C}$ content and microbial biomass $\mathrm{C}$ had decreased by half, but there was still sufficient available $\mathrm{C}$ to support denitrification. The data suggest that the denitrification wall was still functioning as well as it was initially right after construction in terms of $\mathrm{NO}_{3}{ }^{-}$ removal and that it will continue to do so in the near future. Further work is still required to determine the longevity of denitrification walls, specifically organic $\mathrm{C}$ content. We predicted that the total $\mathrm{C}$ in the New Zealand denitrification wall will not be depleted for a total 66 years, although it is likely available $\mathrm{C}$ will become limited to denitrifiers before then.

Long-term studies on denitrification walls are lacking; more research needs to be conducted on the effectiveness of denitrification walls made of varying $\mathrm{C}$ material (particularly biomass as it is readily available on farms), and on walls located in various climates, soils, and groundwater systems, especially in areas where the water table would never be below the wall. Since available $\mathrm{C}$ is the $\mathrm{C}$ source directly 
available to denitrifiers, it would be beneficial to predict available $\mathrm{C}$ decline into the future to determine longevity. In this study, available $\mathrm{C}$ plateaued and we could not usefully extrapolate available $\mathrm{C}$ decline into the future. Future studies should be undertaken to determine the relationship between total $\mathrm{C}$ and available $\mathrm{C}$ so that this relationship can be used to predict when denitrification will become $\mathrm{C}$ limited and $\mathrm{NO}_{3}{ }^{-}$removal will decrease. 


\section{Summary and Conclusions}

\subsection{Conclusions}

Denitrification walls are inexpensive to construct and generally require no maintenance. The low cost of this technology make it an appealing option for removing $\mathrm{NO}_{3}{ }^{-}$from groundwater. However, little is known about the sustainability of denitrification walls as none have yet failed due to $\mathrm{C}$ depletion. This thesis examined the longevity of denitrification walls by investigating a wall constructed in New Zealand in 1996. The main conclusions that were drawn were:

- The denitrification wall located in New Zealand remained effective at removing $\mathrm{NO}_{3}{ }^{-}$after 14 years.

I found $92 \% \mathrm{NO}_{3}{ }^{-}$removal from groundwater, high rates of DEA, and continued supply of available $\mathrm{C}$ in year 14 . Denitrification remained limited by $\mathrm{NO}_{3}{ }^{-}$, not $\mathrm{C}$, indicating that there was sufficient $\mathrm{C}$ available to denitrifiers. The data indicated that the wall was still effective and likely to continue to remove $\mathrm{NO}_{3}{ }^{-}$for the near future. Upon applying a $\mathrm{C}$ decay curve to the total $\mathrm{C}$ data, I predicted that the total $\mathrm{C}$ in the denitrification wall would not decline below $0.1 \%$ for another 52 years (66 years in total). Using stoichiometric equations, a denitrification wall in Canada with $20 \%$ sawdust by weight was predicted to remove $\mathrm{NO}_{3}{ }^{-}$for 200 years (Robertson and Cherry, 1995). Since the New Zealand denitrification wall is $5 \%$ sawdust by weight, this thesis and Robertson and Cherry (1995) predict a similar time estimate for the longevity of denitrification walls. At some point, the fraction of available $\mathrm{C}$ being released from total $\mathrm{C}$ will decrease to an extent that it can no longer support denitrification. As denitrification becomes $\mathrm{C}$ limited, $\mathrm{NO}_{3}{ }^{-}$removal will decline, most likely before the total $\mathrm{C}$ is depleted. It is difficult to predict when this will occur.

- $\quad$ Total C, available C, and DEA are greater lower in the denitrification wall. 
Total $\mathrm{C}$ and available $\mathrm{C}$ were greatest at $90 \mathrm{~cm}$ depth in the wall indicating that $\mathrm{C}$ decay was slower at lower depth, most likely due to anaerobic conditions below the water table. During the dry season or during drought periods when water table declines, it is likely that the shallower soils become aerobic causing decomposition of $\mathrm{C}$ to increase. On the other hand, the deeper soils retain some moisture which limits $\mathrm{O}_{2}$ diffusion thereby slowing $\mathrm{C}$ decomposition (Moorman et al., 2010). Although DEA rates peaked at $50 \mathrm{~cm}$, DEA rates at $90 \mathrm{~cm}$ were higher than observed in the surface soils. The sampling through the soil profile showed that while $\mathrm{C}$ may become depleted in the shallow soils over time, decomposition at depth is slower, and so there will still be enough $\mathrm{C}$ in the deeper soils to promote high $\mathrm{NO}_{3}{ }^{-}$removal through denitrification. This would suggest that sites with fluctuating water tables will become $\mathrm{C}$ depleted faster than sites with constantly high water tables.

I have demonstrated that a denitrification wall remained effective for $\mathrm{NO}_{3}{ }^{-}$removal after 14 years, but the technology does have some limitations. For this technology to be cost effective it is limited to shallow groundwater tables; the cost of construction would become prohibitive if the water table is too deep.

The denitrification wall in New Zealand was installed down to $1.5 \mathrm{~m}$ depth on the edge of a paddock on a dairy farm receiving effluent from Hautapu Dairy Factory. The shallow groundwater table was not confined and when the water table dropped during the dry season (summer), the groundwater flowed below the wall rendering the wall ineffective. Similarly, there appeared to be rerouting of groundwater around the side of the denitrification wall as shown by the high $\mathrm{NO}_{3}{ }^{-}$concentrations in the groundwater in well 10 within and downslope of the wall (Figure 3.2). These issues indicate that constructing a denitrification wall on an agricultural field with an unconfined aquifer is problematic. Denitrification walls would be ideal in areas where the shallow groundwater table is confined and the direction of groundwater flow is stable and known. This would allow for the groundwater to be easily intercepted by the wall and would avoid rerouting underneath or around the wall. For example, denitrification walls would be ideal around tile drains and septic tanks 
where the groundwater is relatively confined and easily intercepted (e.g. Robertston and Cherry, 1995; Jaynes et al., 2008).

\subsection{Future Research}

The main area for further research on denitrification walls is longevity. Since longevity is mainly affected by $\mathrm{C}$ content and supply within the denitrification wall, more studies of $\mathrm{C}$ cycling should be completed. Since available $\mathrm{C}$ is the $\mathrm{C}$ source directly available to denitrifiers, I attempted to predict available $\mathrm{C}$ decline into the future, but since changes in available $\mathrm{C}$ with time had plateaued, I was not able to usefully extrapolate the data out into the future to predict the longevity of the wall. In contrast, a first order $\mathrm{C}$ decay curve was fitted to the changes in total $\mathrm{C}$ with time, which predicted that total $\mathrm{C}$ would reach $<0.1 \%$ in 66 years. However, it is unclear when total $\mathrm{C}$ would become too low to support denitrification. Future studies should be undertaken to determine the relationship between total $\mathrm{C}$ and available $\mathrm{C}$ so that this relationship can be used to predict when denitrification will become $\mathrm{C}$ limited and $\mathrm{NO}_{3}{ }^{-}$removal will decrease.

While predicting available $\mathrm{C}$ decline will be a useful indicator of longevity, it does not tell the whole story. In this study, I was able to demonstrate a significant relationship between DEA and available C (Tiedje, 1988; Schipper et al., 1994) further supporting the hypothesis that denitrification is dependent on available $\mathrm{C}$. Studies should be conducted to determine when DEA rates will become too low to support $\mathrm{NO}_{3}{ }^{-}$removal. Using the minimum DEA value needed to support $\mathrm{NO}_{3}{ }^{-}$ removal, the lowest level of available $\mathrm{C}$ needed to support an adequate level of denitrification can be estimated using the relationship I presented in this thesis. A relationship between total $\mathrm{C}$ and available $\mathrm{C}$ can be used to predict available $\mathrm{C}$ decline into the future, and then the minimum available $\mathrm{C}$ value needed to support $\mathrm{NO}_{3}{ }^{-}$removal can be used to predict how long the denitrification wall will be effective.

With the inclusion of this study, there have now been three long-term studies on denitrification walls in various locations throughout the world. Each of the three 
denitrification walls was constructed with various $\mathrm{C}$ sources, $5 \%$ sawdust by weight amended with site soil (Schipper and Vojvodic-Vukovic, 1998), 20\% sawdust amended with soil (Robertson and Cherry, 1995), and 100\% woodchips (Jaynes et al., 2008). All three walls have been effective for many years, demonstrating that denitrification walls can be effective when using different types and amounts of $\mathrm{C}$ material, although it should be noted that each of the three walls treated different amounts and concentrations of $\mathrm{NO}_{3}{ }^{-}$. More research should be conducted by constructing new denitrification walls using various $\mathrm{C}$ sources. Ideally, denitrification walls should be constructed using $\mathrm{C}$ sources that are readily available and inexpensive. Biomass (e.g. maize cobs) tends to be readily available on farms, but also more labile and easily broken down than woodchips, so it would be beneficial to determine the longevity of denitrification walls using alternative biomass sources. Using $0.2 \mathrm{~m}^{3}$ barrels that imitated denitrification beds, Cameron and Schipper (2010) found that maize cobs had the highest $\mathrm{NO}_{3}{ }^{-}$removal rate after 2 years compared to green waste, wheat straw, and various sizes of Pinus radiata woodchip, but it is unclear how long the maize cobs could support $\mathrm{NO}_{3}{ }^{-}$removal.

A denitrification wall constructed in Canada was effective after 15 years (Robertson et al., 2008) and a wall in Iowa, USA was still functioning after 9 years (Moorman et al., 2010). The North Island, New Zealand, where the denitrification wall in this study was constructed, has a much warmer climate than Iowa and Canada, and so these studies show the effectiveness of denitrification walls in different climates. Even so, these three studies are not enough to fully determine the application of denitrification walls throughout the world. New denitrification walls should be constructed in various countries with differing climates and soil types to determine if walls are feasible under a broader range of conditions. Long-term studies will also need to be undertaken in order to determine how climate, soil type, and various groundwater systems affect long-term sustainability.

No denitrification walls have yet failed due to $\mathrm{C}$ depletion. Field studies should continue on the existing denitrification walls to determine longevity. At some point in the future, $\mathrm{C}$ levels will become too low to support denitrification; it will be 
valuable to continue studying existing walls until they reach this point. It is also important to continue to sample denitrification walls to determine when the efficiency may decrease. For example, a denitrification wall may promote denitrification for many years, but at such a low level that not much of the $\mathrm{NO}_{3}{ }^{-}$is being removed. All three long-term studies on denitrification walls have shown that after 9 years or more, $\mathrm{NO}_{3}{ }^{-}$removal continued to be very high. It appears that there was sufficient $\mathrm{C}$ within the three walls to support high rates of denitrification. It is also important to note that all three walls were constructed with various types and amounts of $\mathrm{C}$ which may affect longevity. Through studying the three existing walls and creating new ones, we can determine the optimum $\mathrm{C}$ type and amount to promote $\mathrm{NO}_{3}{ }^{-}$removal longterm as well as determining the applicability of this technology worldwide.

To date, denitrification walls have proven to be a cost-effective, long-term technology for reducing $\mathrm{NO}_{3}{ }^{-}$concentrations in groundwater. If these walls are used wisely (e.g. in areas of confined shallow aquifers), they are a realistic and affordable technology that could be used in a wide variety of settings. 


\section{References}

Arango, C.P., J.L. Tank, J.L. Schaller, T.V. Royer, M.J. Bernot and M.B. David. 2007. Benthic Organic Carbon Influences Denitrification in Streams with High Nitrate Concentration. Freshwater Biology. 52: 1210-1222.

Barkle, G.F., L.A. Schipper, C.P. Burgess, J. Milne and B.D. Painter. 2008. In Situ Mixing of Organic Matter Decreases Conductivity of Denitrification Walls in Sand Aquifers. Ground Water Monitoring and Remediation. 28: 57-64.

Barton, L., C.D.A. McLay, L.A. Schipper, and C.T. Smith. 1999. Denitrification Rates in a Wastewater-Irrigated Forest Soil in New Zealand. Journal of Environmental Quality. 28: 2008-2014.

Beaulieu, J.J., C.P. Arango, and J.L. Tank. 2009. The Effects of Season and Agriculture on Nitrous Oxide Production in Headwater Streams. Journal of Environmental Quality. 38: 637-646.

Bockle, R., R. Rohmann and A. Wertz. 1986. Process for Restoring Nitrate Contaminated Ground Waters by Means of Heterotrophic Denitrification in an Activated Carbon Filter and Aerobic Post-Treatment Underground. Aqua. 5: 286-287.

Bolan, N.S., D.J. Horne, L.D. Currie. 2004. Growth and Chemical Composition of Legume-Based Pasture Irrigated with Dairy Farm Effluent. New Zealand Journal of Agricultural Research. 47: 85-93.

Boussaid, F., G. Martin, J. Morvan, J.J. Collin, A. Landreau and H. Talbo. 1988. Denitrification In Situ of Groundwaters with Solid Carbon Matter. Environmental Technology Letters. 9(8): 803-816.

Brix, H. 1997. Do Macrophytes Play a Role in Constructed Treatment Wetlands? Water Science and Technology. 35(5): 11-17.

Burford, J.R. and J.M. Bremner. 1975. Relationships Between the Denitrification Capacities of Soils and Total, Water-Soluble and Readily Decomposable Soil Organic Matter. Soil Biology \& Biochemistry. 7: 389-394.

Burgin, A.J. and S.K. Hamilton. 2007. Have We Overemphasized the Role of Denitrification in Aquatic Ecosystems? A Review of Nitrate Removal Pathways. Frontiers in Ecology and the Environment. 5(2): 89-96.

Camargo, J.A. and A. Alonso. 2006. Ecological and Toxicological Effects of Inorganic Nitrogen Pollution in Aquatic Ecosystems: A Global Assessment. Environment International. 32: 831-849. 
Cameron, S.G. and L.A. Schipper. 2010. Nitrate Removal and Hydraulic

Performance of Organic Carbon for Use in Denitrification Beds. Ecological Engineering. 36(11): 1588-1595.

Carpenter, S.R., N.E. Caraco, D.L. Correll, R.W. Howarth, A.N. Sharpley, and V.H. Smith. 1998. Nonpoint Pollution of Surface Waters With Phosphorus and Nitrogen. Ecological Applications. 8(3): 559-568.

Close, M.E., M.R. Rosen, and V.R. Smith. 2001. Fate and Transport of Nitrates and Pesticides in New Zealand's Aquifers. In "Groundwaters of New Zealand", (M.R. Rosen and P.A. White, eds). New Zealand Hydrological Society Inc. Wellington. P. 185-220.

Di, H.J. and K.C. Cameron. 2002. Nitrate Leaching and Pasture Production from Different Nitrogen Sources on a Shallow Stoney Soil Under Flood-Irrigated Dairy Pasture. Australian Journal of Soil Research. 40: 317-334.

Dinnes, D.L., D.L. Karlen, D.B. Jaynes, T.C. Kaspar, J.L. Hatfield, T.S. Colvin and C.A. Cambardella. 2002. Nitrogen Management Strategies to Reduce Nitrate Leaching in Tile-Drained Midwestern Soils. Agronomy Journal. 94: 153-171.

Edgar, N.B. 2009. Icon Lakes in New Zealand: Managing the Tension Between Land Development and Water Resource Protection. Society and Natural Resources. 22: 1-11.

Elgood, Z., W.D. Robertson, S.L. Schiff and R. Elgood. Nitrate Removal and Greenhouse Gas Production in a Stream-Bed Denitrifying Bioreactor. Ecological Engineering. 36(11): 1575-1580.

Elmi, A.A., C. Madramootoo, M. Egeh, A. Liu and C. Hamel. 2002. Environmental and Agronomic Implications of Water Table and Nitrogen Fertilization Management. Journal of Environmental Quality. 31: 1858-1867.

Elmi, A., D. Burton, R. Gordon, and C. Madramootoo. 2005. Impacts of Water Table Management on N2O and N2 from a Sandy Loam Soil in Southwestern Quebec, Canada. Nutrient Cycling in Agroecosystems. 72: 229-240.

Falkowski, P.G. 1997. Evolution of the Nitrogen Cycle and its Influence on the Biological Sequestration of $\mathrm{CO}_{2}$ in the Ocean. Nature. 387: 272-274.

Galloway, J.N. 1998. The Global Nitrogen Cycle: Changes and Consequences. Environmental Pollution. 102(S1): 15-24.

Galloway, J.N., J.D. Aber, J.W. Erisman, S.P. Seitzinger, R.W. Howarth, E.B. Cowling, and B.J. Cosby. 2003. The Nitrogen Cascade. Bioscience. 53(4): 341356.

Gersberg, R.M., B.V. Elkins, and C.R. Goldman. 1983. Nitrogen Removal in Artificial Wetlands. Water Research. 17(9): 1009-1014. 
Gilliam, J.W. and R.W. Skaggs. 1986. Controlled Agricultural Drainage to Maintain Water Quality. Journal of Irrigation and Drainage. 112(3): 254-263.

Groffman, P.M., M.A. Altabet, J.K. Bohlke, K. Butterbach-Bahl, M.D. David, M.K. Firestone, A.E. Giblin, T.M. Kana, L.P. Nielsen, and M.A. Voytek. 2006. Methods for Measuring Denitrification: Diverse Approaches to a Difficult Problem. Ecological Applications. 16: 2091-2122.

Gruber, N. and J.N. Galloway. 2008. An Earth-System Perspective of the Global Nitrogen Cycle. Nature. 451: 293-296.

Hamilton, D. 2005. Land Use Impacts on Nutrient Export in the Central Volcanic Plateau, North Island. NZ Journal of Forestry. 49(4): 27-31.

Hanson, G.C., P.M. Groffman and A.J. Gold. 1994. Denitrification in Riparian Wetlands Receiving High and Low Groundwater Nitrate Inputs. Journal of Environmental Quality. 23: 917-922.

Haynes, R.J. 1999. Size and Activity of the Soil Microbial Biomass under Grass and Arable Management. Biology and Fertility of Soils. 30: 210-216.

Hiscock, K.M., J.W. Lloyd, and L.N. Lerner. 1991. Review of natural and artificial denitrification of groundwater. Water Research. 25(9): 1099-1111.

Hunt, P.G., K.C. Stone, T.A. Matheny, M.E. Poach, M.B. Vanotti and T.F. Ducey. 2009. Denitrification of Nitrified and Non-Nitrified Swine Lagoon Wastewater in the Suspended Sludge Layer of Treatment Wetlands. Ecological Engineering. 35: 1514-1522.

Hunter, W.J. 2001. Use of Vegetable Oil in a Pilot-Scale Denitrifying Barrier. Journal of Contaminant Hydrology. 53: 119-131.

Inwood, S.E., J.L. Tank and M.J. Bernot. 2007. Factors Controlling Sediment Denitrification in Midwestern Streams of Varying Land Use. Microbial Ecology. 53: 247-258.

Jacinthe, P., W.A. Dick and L.C. Brown. 1999. Bioremediation of NitrateContaminated Shallow Soils Using Water Table Management Techniques: Nitrate Removal Efficiency. Transactions of ASAE. 42: 1251-1259.

Janda, V., J. Rudovsky, J. Wanner and K. Marha. 1988. In Situ Denitrification of Drinking Water. Water Science \& Technology. 20(3): 215-219.

Jaynes, D.B., T.C. Kaspar, T. B. Moorman and T.B. Parkin. 2008. In Situ Bioreactors and Deep Drain-Pipe Installation to Reduce Nitrate Losses in Artificially Drained Fields. Journal of Environmental Quality. 37: 429-436.

Jensen, F.B. 2003. Nitrite Disrupts Multiple Physiological Function in Aquatic Animals. Comparative Biochemistry and Physiology. 135(1): 9-24. 
Kadlec, R.H. and R.L. Knight. 1996. Treatment Wetlands. Lewis Publishers. Boca Raton, FL.

Kadlec, R.H. 2009. Comparison of Free Water and Horizontal Subsurface Treatment Wetlands. Ecological Engineering. 35:159-174.

Khan, I.A. and R.F. Spalding. 2004. Enhanced In Situ Denitrification for a Municipal Well. Water Research. 38: 3382-3388.

Knight, R.L., V.W.E. Payne Jr., R.E. Borer, R.A. Clarke Jr., and J.H. Pries. 2000. Constructed Wetlands for Livestock Wastewater Management. Ecological Engineering. 15: 41-55.

Koerselman, W. and A.F.M. Meuleman. 1996. The Vegetation N:P Ratio: A New Tool to Detect the Nature of Nutrient Limitation. Journal of Applied Ecology. 33: 1441-1450.

Kruithof, J. C., J.A.M. van Paassen, W.A.M. Hijnen, H.A.L. Dierx and C.A. van Bennekom. 1985. Experiences with Nitrate Removal in the Eastern Netherlands. Unpublished Conference Proceedings, Paris. 22-24 October.

Ledgard, S.F. 2001. Nitrogen Cycling in Low Input Legume-Based Agriculture, with Emphasis on Legume/Grass Pastures. Plant and Soil. 228: 43-59.

Leverenz, H.L., K. Haunschild, G. Hopes, G. Tchobanoglous, and J.L. Darby. 2010. Anoxic Treatment Wetlands for Denitrification. Ecological Engineering. 36(11): 1544-1551.

Lowrance, R., J.C. Johnson Jr., G.L. Newton and R.G. Williams. 1998. Denitrification from Soils of a Year-Round Forage Production System Fertilized with Liquid Dairy Manure. Journal of Environmental Quality. 27(6): 1504-1511.

Mercado, A., M. Libhaber, and M.I.M. Soares. 1988. In Situ Biological Groundwater Denitrification: Concepts and Preliminary Field Tests. Water Science and Technology. 20: 197-209.

Moorman, T.B., T.B. Parkin, T.C. Kaspar, and D.B. Jaynes. 2010. Denitrification activity, wood loss, and $\mathrm{N} 2 \mathrm{O}$ emissions over 9 years from a wood chip bioreactor. Ecological Engineering. 36(11): 1567-1574.

Mulholland, P.J., et al. 2008. Stream Denitrification across Biomes and its Response to Anthropogenic Nitrate Loading. Nature. 452: 202-205.

Myrold, D.D. 2004. Microbial nitrogen transformations. In "Principles and Applications of Soil Microbiology", 2nd Edition (D.M. Sylvia, J.J. Fuhrmann, P.G. Hartel, and D.A. Zuberer, eds.). Prentice Hall, Upper Saddle River, NJ. p. 333-372. 
Nichol, S.E., M.J. Harvey and I.S. Boyd. 1997. Ten Years of Rainfall Chemistry in New Zealand. Clean Air. 31: 30-37.

Parfitt, R.L., L.A. Schipper, W.T. Baisden and A.H. Elliott. 2006. Nitrogen Inputs and Outputs for New Zealand in 2001 at National and Regional Scales. Biogeochemistry. 80: 71-88.

Parfitt, R.L., W.T. Baisden, L.A. Schipper and A.D. Mackay. 2008. Nitrogen Inputs and Outputs for New Zealand at National and Regional Scales: Past, Present and Future Scenarios. Journal of the Royal Society of New Zealand. 38(2): 7187.

Parliamentary Commissioner for the Environment (PCE). 2004. Growing for Good: Intensive Farming, Sustainability and New Zealand's Environment. Final Report. Wellington, New Zealand. 238p.

Powell, G.E., A.D. Ward, D.E. Mecklenburg and A.D. Jayakaran. 2007. Two-stage channel systems: Part 1, a practical approach for sizing agricultural ditches. Journal of Soil and Water Conservation. 62(4): 277-286.

Powlson, D.S., T.M. Addiscott, N. Benjamin, K.G. Cassman, T.M. de Kok, H. van Grinsven, J. L'hirondel, A.A. Avery and C. van Kessel. 2008. When Does Nitrate Become a Risk for Humans? Journal of Environmental Quality. 37: 291-295.

Rabalais, N.N. 2002. Nitrogen in Aquatic Ecosystems. AMBIO. 31(2): 102-112.

Randall, D.J. and T.K.N. Tsui. 2002. Ammonia Toxicity in Fish. Marine Pollution Bulletin. 45: 17-23.

Richard, Y. 1989. Operating Experiences of Full-Scale Biological and Ion-Exchange Denitrification Plants in France. Journal of the Institution of Water and Environmental Management. 3: 154-167.

Robertson, G.P. and P.M. Vitousek. 2009. Nitrogen in Agriculture: Balancing the Cost of an Essential Resource. Annual Review of Environment and Resources. 34: 97-125.

Robertson, W.D. and J.A. Cherry. 1995. In Situ Denitrification of Septic-System Nitrate Using Reactive Porous Media Barriers: Field Trials. Ground Water. 33(1): 99-111.

Robertson, W.D., D.W. Blowes, C.J. Ptacek and J.A. Cherry. 2000. Long-Term Performance of In Situ Reactive Barriers for Nitrate Remediation. Ground Water. 38(5): 689-695.

Robertson, W.D., G.I. Ford and P.S. Lombardo. 2005. Wood-Based Filter for Nitrate Removal in Septic Systems. Transactions of the ASAE. 48: 121-128. 
Robertson, W.D, C.J. Ptacek, and S.J. Brown. 2007. Geochemical and

Hydrogeological Impacts of a Wood Particle Barrier Treating Nitrate and Perchlorate in Groundwater. Groundwater Monitoring \& Remediation. 27(2): 85-95.

Robertson, W.D., J.L. Vogan and P.S. Lombardo. 2008. Nitrate Removal Rates in a 15-Year-Old Permeable Reactive Barrier Treating Septic System Nitrate. Ground Water Monitoring \& Remediation. 28(3): 65-72.

Robertson, W.D. and L.C. Merkley. 2009. In-Stream Bioreactor for Agricultural Nitrate Treatment. Journal of Environmental Quality. 38: 230-237.

Robertson, W.D. 2010. Nitrate Removal Rates in Woodchip Media of Varying Age. Ecological Engineering. 36(11): 1581-1587.

Rocca, C.D., V. Belgiomo, and S. Meric. 2005. Cotton-Supported Heterotrophic Denitrification of Nitrate-Rich Drinking Water with a Sand Filtration PostTreatment. Water SA. 31(2): 229-236.

Roennefahrt, K.W. 1986. Nitrate Elimination with Heterotrophic Aquatic Microorganisms in Fixed Bed Reactors with Buoyant Carriers. Aqua. 5: 283285.

Rogalla, F., P. Ravarini, G. De Larminat and J. Couttelle. 1990. Large Scale Biological Nitrate and Ammonia Removal. Journal of the Institution of Water and Environmental Management. 4(4): 319-329.

Royer, T.V., J.L. Tank and M.B. David. 2004. Transport and Fate of Nitrate in Headwater Agricultural Streams in Illinois. Journal of Environmental Quality. 33: 1296-1304.

Rupert, M.G. 2008. Decadal-Scale Changes of Nitrate in Ground Water of the United States, 1988-2004. Journal of Environmental Quality. 37: S-240-S-248.

Schaller, J.L., T.V. Royer and M.B. David. 2004. Denitrification Associated with Plants and Sediments in an Agricultural Stream. Journal of the North American Benthological Society. 23(4): 667-676.

Schipper, L.A., A.B. Cooper, C.G. Harfoot, and W.J. Dyck. 1993. Regulators of Denitrification in an Organic Riparian Soil. Soil Biology \& Biochemistry. 25(7): 925-933.

Schipper, L.A., C.G. Harfoot, P.N. McFarlane, and A.B. Cooper. 1994. Anaerobic Decomposition and Denitrification during Plan Decomposition in an Organic Soil. Journal of Environmental Quality. 23: 923-928.

Schipper, L.A. and M. Vojvodic-Vukovic. 1998. Nitrate Removal from Groundwater Using a Denitrification Wall Amended with Sawdust: Field Trial. Journal of Environmental Quality. 27: 664-668. 
Schipper, L.A. and M. Vojvodic-Vukovic. 2000. Nitrate Removal from Groundwater and Denitrification Rates in a Porous Treatment Wall Amended with Sawdust. Ecological Engineering. 14: 269-278.

Schipper, L.A. and M. Vojvodic-Vukovic. 2001. Five Years of Nitrate Removal, Denitrification, and Carbon Dynamics in a Denitrification Wall. Water Research. 35(14): 3473-3477.

Schipper, L.A., G.F. Barkle, M. Vojvodic-Vukovic, J.C. Hadfield and C.P. Burgess. 2004. Hydraulic Constraints on the Performance of a Groundwater Denitrification Wall for Nitrate Removal from Shallow Groundwater. Journal of Contaminant Hydrology. 69: 263-279.

Schipper, L.A., G.F. Barkle, and M. Vojvodic-Vukovic. 2005. Maximum Rates of Nitrate Removal in a Denitrification Wall. Journal of Environmental Quality. 34: $1270-1276$.

Schipper, L.A. and A. McGill. 2008. Nitrogen Transformation in a Denitrification Layer Irrigated with Dairy Factory Effluent. Water Research. 42(10-11): 24572464.

Schipper, L.A., W. Robertson, A.J. Gold, D.B. Jaynes, and S.C. Cameron. 2010a. Denitrifying Bioreactors - An Approach for Reducing Nitrate Loads to Receiving Waters. Ecological Engineering. 36(11): 1532-1543.

Schipper, L.A., S.C. Cameron, and S. Warneke. 2010b. Nitrate Removal from Three Different Effluents Using Large-Scale Denitrification Beds. Ecological Engineering. 36(11): 1552-1557.

Schlesinger, W.H. 2009. On the Fate of Anthropogenic Nitrogen. Proceedings of the National Academy of Sciences. 106(1): 203-208.

Seitzinger, S.P. 1988. Denitrification in Freshwater and Coastal Marine Ecosystems: Ecological and Geochemical Significance. Limnology and Oceanography. 33(4, part 2): 702-724.

Seitzinger, S., J. A. Harrison, J.K. Bohlke, A.F. Bouwman, R. Lowrance, B. Peterson, C. Tobias, and G. Van Drecht. 2006. Denitrification across Landscapes and Waterscapes: A Synthesis. Ecological Applications. 16(6): 2064-2090.

Smil, V. 1997. Global Population and the Nitrogen Cycle. Nature. Scientific America. 277: 76-81.

Soares, M.I.M., C. Braester, S. Belkin and A. Abeliovich. 1991. Denitrification in Laboratory Sand Columns: Carbon Regime, Gas Accumulation, and Hydraulic Properties. Water Research. 25(3): 352-332.

Soares, M.I.M. 2000. Biological denitrification of groundwater. Water, Air, and Soil Pollution. 123: 183-193. 
Songliu, L., H. Hongying, S. Yingxue and Y. Jia. 2009. Effect of Carbon Source on the Denitrification in Constructed Wetlands. Journal of Environmental Sciences. 21: 1036-1043.

Spalding, R.F. and M.E. Exner. 1993. Occurrence of Nitrate in Groundwater-A review. Journal of Environmental Quality. 22(3): 392-402.

Sparling, G.P. and C. Zhu. 1993. Evaluation and Calibration of Methods to Measure Microbial Biomass C and N in Soils from Western Australia. Soil Biology and Biochemistry. 25: 1793-1801.

Sparling, G.P., L.A. Schipper, and J.M. Russell. 2001. Changes in Soil Properties After Application of Dairy Factory Effluent to New Zealand Volcanic Ash and Pumice Soils. Australian Journal of Soil Research. 39: 505-518.

Stenzel, A. and R. Herrmann. 1990. Comparing the Effects of Acidic Deposition on the Chemistry of Small Stream in the South Island of New Zealand with those in Fichtelgebirge. F.R.G. Catena. 17: 69-83.

Strock, J.S., C.J. Dell and J.P. Schmidt. 2007. Managing Natural Processes in Drainage Ditches for Nonpoint Source Nitrogen Control. Journal of Soil and Water Conservation. 62(4): 188-196.

Tank, J.L. and W.K. Dodds. 2003. Nutrient Limitation of Epilithic and Epixylic Biofilms in Ten North American Streams. Freshwater Biology. 48: 1031-1049.

Tiedje, J.M. 1988. Ecology of Denitrification and Dissimilatory Nitrate Reduction to Ammonium. In "Biology of Anaerobic Microorganisms". J.B. Zehnder, ed. Wiley, New York, New York, USA. P. 179-244.

Tiedje, J.M., S. Simkins, and P.M. Groffman. 1989. Perspectives on Measurement of Denitrification in the Field Including Recommended Protocols for Acetylene Based Methods. Plant Soil. 115: 261-284.

Tozer, W.C., K.J. Wilkins, H. Wang, M. Van den Heuvel, T. Charleson and W.B. Silvester. 2005. Using 15N to Determine a Budget for Effluent-Derived Nitrogen Applied to Forest. Isotopes in Environmental and Health Studies. 41(1): 13-30.

USDA-National Resources Conservation Service. 2010. Keys to Soil Taxonomy, $11^{\text {th }}$ ed. Washington, D.C.

Vance, E.D., P.C. Brookes and D.S. Jenkinson. 1987. An Extraction Method for Measuring Soil Microbial Biomass C. Soil Biology and Biochemistry. 19(6): 703-707.

van Driel, P.W., W.D. Robertson and L.C. Merkley. 2006. Upflow Reactors for Riparian Zone Denitrification. Journal of Environmental Quality. 35: 412-420. 
Vitousek, P.M., J.D. Aber, R.W. Howarth, G.E. Likens, P.A. Matson, D.W. Schindler, W.H. Schlesinger, and D.G. Tilman. 1996. Human Alteration of the Global Nitrogen Cycle: Sources and Consequences. Ecological Applications. 7(3): 737-750.

Vogan, J.L., R.M. Focht, D.K. Clark, and S.L. Graham. 1999. Performance Evaluation of a Permeable Reactive Barrier for Remediation of Dissolved Chlorinated Solvents in Groundwater. Journal of Hazardous Materials. 68: 97108.

Wang, H., G. Magesan, and N Bolan. 2004. An overview of the Environmental Effects of Land Application of Farm Effluents. New Zealand Journal of Agricultural Research. 47: 389-403.

Whalen, J.K., C. Chang, B.M. Olson. 2001. Nitrogen and Phosphorus Mineralization Potentials of Soils Receiving Repeated Annual Cattle Manure Applications. Biology and Fertility of Soils. 34: 334-341.

Woli, K.P., M.B. David, R.A. Cooke, G.F. McIsaac, and C.A. Mitchell. 2010. Nitrogen Balance in and Export from Agricultural Fields Associated with Controlled Drainage Systems and Denitrifying Bioreactors. Ecological Engineering. 36(11): 1558-1566.

Zaman, M., M.L. Nguyen, A.J. Gold, P.M. Groffman, D.Q. Kellogg and R.J. Wilcock. 2008. Nitrous Oxide Generation, Denitrification, and Nitrate Removal in a Seepage Wetland Intercepting Surface and Subsurface Flows from a Grazed Dairy Catchment. Australian Journal of Soil Research. 46: 565-577. 


\section{Appendix A}

\section{Nitrate Removal and Biochemistry}

\section{Soil and Water Sampling}

In order to compare this study to the 1996 study on the denitrification wall, measurements were made according to Schipper and Vojvodic-Vukovic (1998), including: DEA; microbial biomass C; available C; soil water content; total C; and groundwater $\mathrm{NO}_{3}{ }^{-}$concentrations.

Each sampling period, 15 June, 20 July, 18 August, and 30 August, six soil samples were taken below the water table within the wall using a Dutch auger (diameter of 6 $\mathrm{cm})$. The soil sample was placed in a plastic bag and stored on ice until returning to the laboratory and then refrigerated at $4^{\circ} \mathrm{C}$ until analyzed. All soil samples were processed and analyzed within 3 days of collection.

Depth profile sampling within the wall was also undertaken. Six sites within the wall were sampled to a depth of $120 \mathrm{~cm}$ at intervals of $20 \mathrm{~cm}$ for a total of 6 samples per site on 23 August 2010. The soil samples were placed in plastic Ziploc bags and stored at $4^{\circ} \mathrm{C}$ in the laboratory until analysis.

In 1996, $3060 \mathrm{~mm}$ diameter slotted polyvinyl chloride (PVC) pipes were installed (10 upslope of the wall, 10 within the wall, and 10 downslope of the wall); the groundwater in these wells was sampled at every site visit, and also on 23 August and 6 September, by taping a sampling bottle to a measuring stick and lowering it into the well. The groundwater within the wells was removed using a battery operated pump the afternoon prior sampling to ensure that the groundwater sample was not contaminated. The water samples were stored on ice until returning to the laboratory where they were immediately filtered and frozen until analyzed.

\section{Soil and Water Analysis}

DEA rates in the soils samples (at $1 \mathrm{~m}$ depth within the wall; $\mathrm{n}=6$ for each sampling period) were measured using a modified method by Tiedje et al. (1989) (reviewed by 
Groffman et al., 2006) by placing $35 \mathrm{~g}$ of fresh soil and a $70 \mathrm{~mL}$ solution containing both $0.2 \mathrm{~g} \mathrm{~L}^{-1}$ glucose and $0.1 \mathrm{~g} \mathrm{~L}^{-1} \mathrm{KNO}_{3}{ }^{-}$into a $350 \mathrm{~mL}$ glass jar with a lid containing a rubber septa. To determine whether $\mathrm{NO}_{3}{ }^{-}$or $\mathrm{C}$ limited the rate of denitrification, each soil sample was partitioned into 3 additional jars: one with a 70 $\mathrm{mL}$ solution containing $0.2 \mathrm{~g} \mathrm{~L}^{-1}$ glucose; one with a $70 \mathrm{~mL}$ solution containing $0.1 \mathrm{~g}$ $\mathrm{L}^{-1} \mathrm{KNO}_{3}{ }^{-}$; and one control. All treatments included $0.12 \mathrm{~g} \mathrm{~L}^{-1}$ chloramphenicol to prevent do novo enzyme synthesis. The jars were then flushed with $\mathrm{N}_{2}$ gas for 10 minutes by placing needles hooked up to a manifold through the septa. $20 \mathrm{~mL}$ of acetylene (7.7\% headspace acetylene) was then injected into each jar through the septa in order to block the conversion of $\mathrm{N}_{2} \mathrm{O}$ to $\mathrm{N}_{2}$. The jars were then placed in an incubator set at $28^{\circ} \mathrm{C}$ and shaken at $200 \mathrm{rpm} .5 \mathrm{~mL} \mathrm{~N}_{2} \mathrm{O}$ samples were taken from each jar at $15,30,45$, and 75 minutes. $\mathrm{N}_{2} \mathrm{O}$ was analyzed on a gas chromatograph (Varian CP-3800; Santa Clara, California) equipped with an electron capture detector. Operating conditions were an oven temperature of $120^{\circ} \mathrm{C}$, injector temperature of $220^{\circ} \mathrm{C}$, a column temperature of $80^{\circ} \mathrm{C}$, and detector temperature of $375^{\circ} \mathrm{C}$. The carrier gas was $10 \%$ methane in argon at a flow rate $30 \mathrm{~mL} \mathrm{~min}^{-1}$ through a packed column.

Microbial biomass $\mathrm{C}$ was measured by chloroform $\left(\mathrm{CHCl}_{3}\right)$ fumigation adapted from Vance et al. (1987). 50g of fresh soil was weighed into $300 \mathrm{~mL}$ plastic bottles and extracted with $200 \mathrm{~mL} 0.5 \mathrm{M} \mathrm{K}_{2} \mathrm{SO}_{4}$ by placing the bottles into and end-over-end shaker for 30 minutes. The extracts were then centrifuged and the supernatant filtered through Advantec $0.45 \mu \mathrm{m}$ membrane filter paper and then placed into $15 \mathrm{~mL}$ plastic bottles. The samples were frozen until sent to be analyzed for total organic $\mathrm{C}$ (TOC) at Landcare Research Ltd. (Hamilton) on a Lachat TOC analyzer (model IL550 TOC). The TOC analyzer uses high temperature thermocatalytic oxidation and a multi-channel infrared detector. For the fumigation, $50 \mathrm{~g}$ of fresh soil was also measured into $100 \mathrm{~mL}$ glass beakers and placed into a desiccator lined with moist tissue paper in order to maintain humidity. A $100 \mathrm{~mL}$ glass beaker containing $25 \mathrm{~mL}$ of purified $\mathrm{CHCl}_{3}$ with a few anti-bumping granules was placed into the desiccator. The desiccator was evacuated using a Rocker 600 vacuum until the $\mathrm{CHCl}_{3}$ had boiled for 2 minutes. The vacuum was then disconnected and the tap on the desiccator was 
closed. The desiccator was placed in a dark incubator set at $25^{\circ} \mathrm{C}$ for 24 hours. After 24 hours, the seal in the desiccator was released and the beaker with the $\mathrm{CHCl}_{3}$ was removed as well as the damp tissues. The lid was placed back on the desiccator and it was evacuated using the vacuum to remove all traces of $\mathrm{CHCl}_{3}$ vapour from the soils. This was achieved by evacuating for 5 minutes, 5 times. The fumigated soils were then extracted as described above for the non-fumigated soils. The filtered extracts were frozen until analyzed for TOC. Microbial biomass was calculated by:

$\mathrm{OC}^{-1}$ soil $=\left[\mathrm{S}\left(\mathrm{V}+\mathrm{V}_{\mathrm{s}}\right)-(\mathrm{B} * \mathrm{~V})\right] / \mathrm{w}$

Where $\mathrm{OC}$ is the organic $\mathrm{C}$ of the soil, $\mathrm{S}$ is the sample $\mathrm{OC} \mathrm{mL}^{-1}, \mathrm{~V}$ is the extractant volume $(\mathrm{mL}), \mathrm{V}_{\mathrm{s}}$ is the soil water volume $(\mathrm{mL}), \mathrm{B}$ is the blank $\mathrm{OC} \mathrm{mL}^{-1}$, and $\mathrm{w}$ is the soil oven dry weight (g). Biomass $\mathrm{C}$ is then calculated by:

Biomass $\mathrm{C}\left(\mathrm{OC} \mathrm{g}^{-1}\right.$ soil $)=$ Extractable $\mathrm{C}$ flush $/ 0.41$

Where extractable $\mathrm{C}$ flush is the difference between the organic $\mathrm{C}$ of fumigated and non-fumigated soils and is converted to biomass $\mathrm{C}$ using the $\mathrm{k}_{\mathrm{EC}}$ factor, which is 0.41 for New Zealand soils (Sparling et al., 2001).

Available C was measured using a modified version of Sparling and Zhu (1993) by placing $25 \mathrm{~g}$ of fresh soil into $1 \mathrm{~L}$ glass jars with lids sealed with Vaseline containing rubber septa. The jars were incubated at $25^{\circ} \mathrm{C}$ for 7 days. After 7 days, $1 \mathrm{~mL}$ gas samples were taken from the headspace and analyzed for $\mathrm{CO}_{2}$ on a LI-COR $\mathrm{CO}_{2} / \mathrm{H}_{2} \mathrm{O}$ analyzer (Model LI-6262) and recorded on a YEW type 3057 portable recorder. The $\mathrm{CO}_{2}$ peak heights were measured manually with a ruler. The volume of $\mathrm{CO}_{2}$ respired per gram of soil was calculated by:

respired $\mathrm{CO}_{2}\left(\mu \mathrm{LCO}_{2} \mathrm{~g}^{-1} \mathrm{~h}^{-1}\right)=\left(\frac{\mathrm{A}}{\text { std }}-\frac{\mathrm{B}}{\mathrm{std}}\right) \times \mathrm{V} \times 10 / 0 \mathrm{DW} / \mathrm{Inc}$ 
where $\mathrm{A}$ is the sample peak height in $\mathrm{mm}$; std is the standard peak height $\left(1 \% \mathrm{CO}_{2}\right)$ in $\mathrm{mm}$; $\mathrm{B}$ is the blank peak height in $\mathrm{mm}$; V is the headspace volume of the bottle in $\mathrm{mL}$; ODW is the oven dry weight of the soil in $\mathrm{g}$; and Inc is the incubation time in $\mathrm{h}$.

Available $\mathrm{C}\left(\mu \mathrm{gCO}_{2} \mathrm{Cg}^{-1} \mathrm{~h}^{-1}\right)=$ respired $\mathrm{C} \times 1.7995 \times 0.2727$

Total $\mathrm{C}$ was measured using a combustion furnace at the department of biological sciences at the University of Waikato on a LECO TruSpec CN Carbon/Nitrogen Determinator. Soil samples were dried at $60^{\circ} \mathrm{C}$ overnight and then ground on a Retsch MM2000 mixer mill grinder. $0.25 \mathrm{~g}$ of dried, ground soil was measured out and placed in foil containers and analyzed on the LECO.

Groundwater $\mathrm{NO}_{3}{ }^{-}$concentrations were analyzed on a Lachat Quikchem FIA 8000 series using a Lachat XYZ Autosampler (ASX 500 series). The water samples were centrifuged for 10 minutes at $3000 \mathrm{rpm}$ and then filtered using Advantec $0.45 \mu \mathrm{m}$ membrane filters and placed into $50 \mathrm{~mL}$ plastic Falcon tubes. The samples were then diluted with deionized water by a factor of ten and placed into $15 \mathrm{~mL}$ Falcon tubes where they were frozen until analyzed.

Soil water content was measured gravimetrically. Aluminium tin was weighed on the balance and then $10-20 \mathrm{~g}$ of fresh soil was added to the tin. The soil samples were dried overnight in a $105^{\circ} \mathrm{C}$ oven and then weighed. By subtracting the total weight by the weight of the tin, the dry soil weight can be calculated. Soil water content is calculated as:

Gravimetric Water Content $=\frac{\text { Wet soil-Oven Dry Soil }}{\text { Oven Dry Soil }}$

\section{Loss of Carbon over Time}

The relationship between available $\mathrm{C}$ and DEA was used to estimate the longevity of $\mathrm{C}$ in the denitrification wall in terms of $\mathrm{NO}_{3}{ }^{-}$removal (Burford and Bremner, 1975). 32 soil samples were taken with a Dutch auger within the denitrification wall, 16 at $0.5 \mathrm{~m}$ and 16 at $1 \mathrm{~m}$ depth. Half of the soil samples (half at $0.5 \mathrm{~m}$ depth and half at 1 m depth) were flushed with $\mathrm{N}_{2}$ gas to create anaerobic conditions, and the other half 
were incubated aerobically in $350 \mathrm{~mL}$ glass jars at $25^{\circ} \mathrm{C}$ for 7 days. After 7 days, available $\mathrm{C}$ and DEA were measured following the methods described above. A linear regression was performed on the data to determine if the relationship between DEA and available $\mathrm{C}$ was significant $(\mathrm{p}<0.05)$. This relationship was then used to predict the amount of available $\mathrm{C}$ left in the denitrification wall when DEA was zero. A decay curve was then fitted to the available $\mathrm{C}$ data, collected over the last 14 years, and the length of time until DEA becomes limited by $\mathrm{C}$ was estimated.

\section{Statistical Analysis}

To determine nutrient limitation, a two-way ANOVA was performed on the data with $\mathrm{NO}_{3}{ }^{-}$and $\mathrm{C}$ as the main factors (Tank and Dodds, 2003). A significant result (p $<0.05)$ for $\mathrm{NO}_{3}{ }^{-}$indicated $\mathrm{NO}_{3}{ }^{-}$limitation, while a significant result $(\mathrm{p}<0.05)$ for $\mathrm{C}$ indicated $\mathrm{C}$ limitation. If the interaction between $\mathrm{NO}_{3}{ }^{-}$and $\mathrm{C}$ was significant $(\mathrm{p}<$ 0.05), then the system was co-limited by $\mathrm{NO}_{3}{ }^{-}$and $\mathrm{C}$. Two-sample t-tests assuming unequal variances were used to compare data from year 1 to year 14 to determine whether the various parameters measured had significantly decreased over time; $\mathrm{p}<$ 0.05 was considered significant. 


\section{Appendix B}

Table B- 1 Groundwater $\mathrm{NO}_{3}^{-}$data for each sampling period. Upslope is the groundwater $\mathrm{NO}_{3}{ }^{-}$concentrations upslope of the wall in mg $\mathrm{N} \mathrm{L}^{-1}$ and wall is the groundwater $\mathrm{NO}_{3}{ }^{-}$concentrations within the wall in $\mathrm{mg} \mathrm{N} \mathrm{L}^{-1}$.

\begin{tabular}{|c|c|c|c|c|c|c|c|c|c|c|}
\hline \multirow[t]{2}{*}{ Well } & \multicolumn{2}{|c|}{15 June } & \multicolumn{2}{|c|}{20 July } & \multicolumn{2}{|c|}{18 August } & \multicolumn{2}{|c|}{23 August } & \multicolumn{2}{|c|}{30 August } \\
\hline & Upslope & Wall & Upslope & Wall & Upslope & Wall & Upslope & Wall & Upslope & Wall \\
\hline 1 & 0.46 & 0.08 & 0.82 & 0.07 & 0.77 & 0 & 0.23 & 0 & 0.4 & 0 \\
\hline 2 & 1.35 & 2.37 & 1.21 & 0.07 & 0.37 & 0.04 & 0.65 & 0.02 & 0 & 0 \\
\hline 3 & 0.92 & No water & 0.55 & 0.02 & 0.56 & 0.26 & 0.38 & 0.01 & 0.37 & n.m. \\
\hline 4 & 0.48 & 0.70 & 0.25 & 0.05 & 0.12 & 0.01 & 0.21 & 0.02 & 0.10 & 0.02 \\
\hline 5 & 0.82 & 0.49 & 1.36 & 0.06 & 0.56 & 0.10 & 0.58 & 0.02 & 1.26 & 0 \\
\hline 6 & 0.39 & No water & 2.15 & 0.11 & 3.01 & 0.50 & 5.0 & 0.55 & 5.81 & 0 \\
\hline 7 & 0.15 & No water & 1.65 & 0.19 & 3.84 & 0.25 & 3.55 & 0.36 & n.m. & 1.2 \\
\hline 8 & 0.23 & 0.60 & 3.83 & 0.07 & 3.96 & 0.64 & 4.67 & 0.90 & 7.18 & 0.74 \\
\hline 9 & 2.57 & 0.05 & 4.89 & 0.07 & 4.71 & 0 & 8.56 & 0.77 & 9.16 & 0 \\
\hline 10 & 1.01 & 0.20 & 5.51 & 0.14 & 5.34 & 0.59 & 2.93 & 1.93 & 5.98 & 5.31 \\
\hline
\end{tabular}


Table B- 2 Data from the soil samples collected on 15 June 2010. Each sample was taken at a depth of approximately $1 \mathrm{~m}$. Total $\mathrm{C}$ is in \%; microbial biomass $\mathrm{C}$ is $\mu \mathrm{g} \mathrm{Cg}^{-1}$ soil; available $\mathrm{C}$ is $\mu \mathrm{g} \mathrm{C} \mathrm{g}{ }^{-1} \mathrm{hr}^{-1}$; denitrifying enzyme activity (DEA) is $\mathrm{ng} \mathrm{N}^{-1} \mathrm{hr}^{-1}$.

\begin{tabular}{lllll}
\hline Sample & Total Carbon & $\begin{array}{l}\text { Microbial Biomass } \\
\text { Carbon }\end{array}$ & Available Carbon & DEA \\
\hline 1 & 1.83 & 419 & 1.30 & 2179 \\
2 & 1.49 & 300 & 1.21 & 1136 \\
3 & n.m. & n.m. & n.m. & n.m. \\
4 & 2.10 & 341 & 1.43 & 0 \\
5 & 2.09 & 399 & 1.13 & 0 \\
6 & 2.19 & 283 & 1.31 & 6494 \\
\hline
\end{tabular}

Table B- 3 Data from the soil samples collected on 20 July 2010. Each sample was taken at a

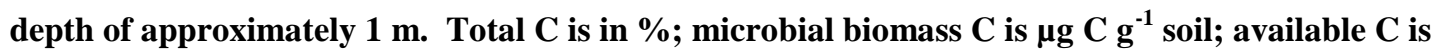
$\mu \mathrm{g} \mathrm{C} \mathrm{g}^{-1} \mathrm{hr}^{-1}$; denitrifying enzyme activity (DEA) is $\mathrm{ng} \mathrm{N} \mathrm{g}^{-1} \mathrm{hr}^{-1}$.

\begin{tabular}{lllll}
\hline Sample & Total Carbon & $\begin{array}{l}\text { Microbial Biomass } \\
\text { Carbon }\end{array}$ & Available Carbon & DEA \\
\hline 1 & n.m. & n.m. & n.m. & n.m. \\
2 & 2.50 & 103 & 1.96 & 2050 \\
3 & 1.00 & 146 & 1.84 & 846 \\
4 & 3.58 & 199 & 3.08 & 616 \\
5 & 1.18 & 113 & 0.87 & 101 \\
6 & 2.55 & 265 & 2.35 & 542 \\
\hline
\end{tabular}


Table B- 4 Data from the soil samples collected on 18 August 2010. Each sample was taken at a depth of approximately $1 \mathrm{~m}$. Total $\mathrm{C}$ is in \%; microbial biomass $\mathrm{C}$ is $\mu \mathrm{g} \mathrm{C} \mathrm{g}^{-1}$ soil; available $\mathrm{C}$ is $\mu \mathrm{g} \mathrm{C} \mathrm{g}^{-1} \mathrm{hr}^{-1}$; denitrifying enzyme activity (DEA) is $\mathrm{ng} \mathrm{N}^{-1} \mathrm{hr}^{-1}$.

\begin{tabular}{lllll}
\hline Sample & Total Carbon & $\begin{array}{l}\text { Microbial Biomass } \\
\text { Carbon }\end{array}$ & Available Carbon & DEA \\
\hline 1 & n.m. & n.m. & n.m. & n.m. \\
2 & 2.00 & 344 & 1.24 & 469 \\
3 & 1.00 & 251 & 1.21 & 881 \\
4 & 2.00 & 440 & 2.36 & 1705 \\
5 & 3.00 & 488 & 2.49 & 1038 \\
6 & 3.70 & 332 & 2.27 & 222 \\
\hline
\end{tabular}

Table B- 5 Data from the soil samples collected on 23 August 2010. Each sample was taken at a depth of approximately $1 \mathrm{~m}$. Total $\mathrm{C}$ is in \%; microbial biomass $\mathrm{C}$ is $\mu \mathrm{g} \mathrm{C}^{-1}$ soil; available $\mathrm{C}$ is $\mu \mathrm{g} \mathrm{C} \mathrm{g}^{-1} \mathrm{hr}^{-1}$; denitrifying enzyme activity (DEA) is $\mathrm{ng} \mathrm{N} \mathrm{g}^{-1} \mathrm{hr}^{-1}$.

\begin{tabular}{lllll}
\hline Sample & Total Carbon & $\begin{array}{l}\text { Microbial Biomass } \\
\text { Carbon }\end{array}$ & Available Carbon & DEA \\
\hline 1 & 1.9 & 334 & 1.50 & 529 \\
2 & 2.7 & 15 & 4.7 & 687 \\
3 & 2.3 & 425 & 2.34 & 580 \\
4 & 2.9 & 360 & 2.42 & 525 \\
5 & 3.0 & 49 & 1.25 & 152 \\
6 & 2.2 & 280 & 1.35 & 688 \\
\hline
\end{tabular}


Table B- 6 The data presented in this thesis. Upslope is the average upslope $\mathrm{NO}_{3}{ }^{-}$concentrations in $\mathrm{mg} \mathrm{N}^{-1}$. Wall is the average $\mathrm{NO}_{3}{ }^{-}$concentrations within the wall in $\mathrm{mg} \mathrm{N} \mathrm{L}^{-1}$. $\mathrm{AC}$ is available $\mathrm{C}$ in $\mu \mathrm{g} \mathrm{C} \mathrm{g}^{-1} \mathrm{hr}^{-1}$. MBC is microbial biomass $\mathrm{C}$ in $\mu \mathrm{g} \mathrm{C} \mathrm{g}^{-1}$ soil. TC it total $\mathrm{C}$ in \%. DEA is denitrifying enzyme activity in $\mathrm{ng} \mathrm{N}^{-1} \mathrm{hr}^{-1}$. SE is standard error for 6 measurements for the soil analyses and 10 measurements for the groundwater analyses.

\begin{tabular}{lllllllllllll}
\hline Date & Upslope & Upslope SE & Wall & Wall SE & AC & AC SE & MBC & MBC SE & TC & TC SE & DEA & DEA SE \\
\hline 15 June & 0.84 & 0.23 & 1.86 & 1.25 & 1.28 & 0.05 & 319 & 36 & 1.9 & 0.13 & 3269 & 1271 \\
20 July & 2.22 & 0.59 & 0.10 & 0.02 & 2.02 & 0.80 & 148 & 36 & 2.2 & 0.48 & 831 & 328 \\
18 August & 2.33 & 0.65 & 0.2 & 0.08 & 1.92 & 0.28 & 331 & 52 & 2.1 & 0.47 & 727 & 249 \\
23 August & 2.67 & 0.89 & 0.29 & 0.12 & 2.26 & 0.53 & 244 & 70 & 2.5 & 0.18 & 527 & 81 \\
30 August & 3.36 & 1.15 & 0.25 & 0.16 & n.m. & n.m. & n.m. & n.m. & n.m. & n.m. & n.m. & n.m. \\
\hline
\end{tabular}


Table B- 7 Data from the soil profile depth samples collected on 23 August 2010. Six soil samples were collected at $20 \mathrm{~cm}$ intervals. Total $\mathrm{C}$ is in \%; microbial biomass $\mathrm{C}$ is $\mu \mathrm{g} \mathrm{C}^{-1}$ soil; available $\mathrm{C}$ is $\mu \mathrm{g} \mathrm{C} \mathrm{g}^{-1} \mathrm{hr}^{-1}$; denitrifying enzyme activity (DEA) is $\mathrm{ng} \mathrm{Ng}^{-1} \mathrm{hr}^{-1}$.

\begin{tabular}{|c|c|c|c|c|c|}
\hline Sample & Depth & $\mathrm{TC}$ & MBC & $\mathrm{AC}$ & DEA \\
\hline 1 & $0-20$ & 1.2 & 600 & 1.14 & 289 \\
\hline 2 & $0-20$ & 1.6 & 495 & 1.09 & 1.29 \\
\hline 3 & $0-20$ & 1.6 & 130 & 1.10 & 1030 \\
\hline 4 & $0-20$ & 1.3 & 245 & 1.00 & 0 \\
\hline 5 & $0-20$ & 1.5 & 624 & 2.12 & 92 \\
\hline 6 & $0-20$ & 1.3 & 505 & 1.12 & 0 \\
\hline 1 & $20-40$ & 1.1 & 282 & 0.41 & 367 \\
\hline 2 & $20-40$ & 1.3 & 420 & 0.96 & 0 \\
\hline 3 & $20-40$ & 1.7 & 583 & 1.20 & 30 \\
\hline 4 & $20-40$ & 1.4 & 92 & 1.18 & 781 \\
\hline 5 & $20-40$ & 1.7 & 491 & 1.13 & 2106 \\
\hline 6 & $20-40$ & 1.7 & 266 & 1.07 & 448 \\
\hline 1 & $40-60$ & 1.4 & 433 & 1.18 & 89 \\
\hline 2 & $40-60$ & 0.9 & 249 & 0.66 & 1077 \\
\hline 3 & $40-60$ & 1.2 & 425 & 1.14 & 1622 \\
\hline 4 & $40-60$ & 1.4 & 483 & 0.98 & 138 \\
\hline 5 & $40-60$ & 2.4 & 578 & 1.33 & 1522 \\
\hline 6 & $40-60$ & 1.7 & 247 & 0.84 & 597 \\
\hline 1 & $60-80$ & 1.1 & 277 & n.m. & 105 \\
\hline 2 & $60-80$ & 1.6 & 261 & n.m. & 961 \\
\hline 3 & $60-80$ & 2.0 & 373 & 2.16 & 911 \\
\hline 4 & $60-80$ & 2.1 & 489 & 2.27 & 1210 \\
\hline 5 & $60-80$ & 2.8 & 661 & 2.74 & 355 \\
\hline 6 & $60-80$ & 2.1 & 157 & 1.21 & 45 \\
\hline 1 & $80-100$ & 1.9 & 334 & 1.50 & 529 \\
\hline 2 & $80-100$ & 2.7 & 15 & 4.70 & 687 \\
\hline 3 & $80-100$ & 2.3 & 425 & 2.34 & 580 \\
\hline 4 & $80-100$ & 2.9 & 360 & 2.42 & 525 \\
\hline
\end{tabular}




\begin{tabular}{llllll}
5 & $80-100$ & 3.0 & 49 & 1.25 & 152 \\
6 & $80-100$ & 2.2 & 280 & 1.35 & 688 \\
1 & $100-120$ & 2.5 & 317 & 1.98 & 236 \\
2 & $100-120$ & 3.0 & n.m. & 1.02 & 0 \\
3 & $100-120$ & 2.1 & 372 & 1.12 & 291 \\
4 & $100-120$ & 1.1 & 240 & 1.36 & 295 \\
5 & $100-120$ & 0.8 & 257 & 0.94 & 36 \\
6 & $100-120$ & 2.6 & 115 & 0.07 & 243 \\
\hline
\end{tabular}

Table B- 8 Data from the loss of carbon experiment. Samples 1, 3, 5, 7, 9, 11, 13, and 15 were incubated aerobically while samples $2,4,6,8,10,12,14$, and 15 were incubated anaerobically. The units for available $\mathrm{C}$ (AC) are $\mu \mathrm{g} \mathrm{C} \mathrm{g}^{-1} \mathrm{hr}^{-1}$ and the units for denitrifying enzyme activity (DEA) are $\mathrm{ng} \mathrm{N} \mathrm{g}{ }^{-1} \mathrm{hr}^{-1}$.

\begin{tabular}{|c|c|c|c|}
\hline Sample & Depth & $\mathrm{AC}$ & DEA \\
\hline 1 & 0.5 & 0.48 & 1023 \\
\hline 2 & 0.5 & 0.55 & 2459 \\
\hline 3 & 0.5 & 0.27 & 32 \\
\hline 4 & 0.5 & 0.54 & 3359 \\
\hline 5 & 0.5 & 0.59 & 212 \\
\hline 6 & 0.5 & n.m. & n.m. \\
\hline 7 & 0.5 & 0.26 & 75 \\
\hline 8 & 0.5 & 0.40 & 1222 \\
\hline 9 & 0.5 & 0.92 & 2966 \\
\hline 10 & 0.5 & 0.44 & 1336 \\
\hline 11 & 0.5 & 0.56 & 252 \\
\hline 12 & 0.5 & 0.53 & 2944 \\
\hline 13 & 0.5 & n.m. & n.m. \\
\hline 14 & 0.5 & 0.52 & 3059 \\
\hline 15 & 0.5 & 0.10 & 0 \\
\hline 16 & 0.5 & 0.46 & 1451 \\
\hline 1 & 1 & 1.03 & 878 \\
\hline 2 & 1 & 0.91 & 506 \\
\hline
\end{tabular}




\begin{tabular}{llll}
3 & 1 & 0.95 & 602 \\
4 & 1 & 0.94 & 288 \\
5 & 1 & 0.58 & 626 \\
6 & 1 & 0.55 & 323 \\
7 & 1 & 0.61 & 2105 \\
8 & 1 & 0.47 & 1194 \\
9 & 1 & 1.54 & 2164 \\
10 & 1 & 1.02 & 1078 \\
11 & 1 & 0.50 & 1166 \\
12 & 1 & 1.56 & 1202 \\
13 & 1 & 0.21 & 129 \\
14 & 1 & 0.59 & 579 \\
15 & 1 & 1.10 & 1910 \\
16 & 1 & 0.50 & 1037 \\
\hline
\end{tabular}




\section{Appendix C}

Reviewers' comments:

Associate Editor:

Both reviews found the manuscript of interest for the Journal. Moderate revision is required. All the comments need to be individually addressed. Some additional editorial comments are as follows.

1. Provide the FAO soil order in the M\&M.

- $\quad$ The soil order has been added to the M\&M.

2. Revise References to meet format requirements - consult a recent copy of AGEE.

- $\quad$ This has been corrected.

3. Keep Table titles to one sentence - place other text as a table footnote.

This has been corrected.

Reviewer \#1:

Authors describe the current denitrification capacity and C stocks remaining in a 14yr old bioreactor. This information is valuable for determining the life expectancy for these structures and will determine their ultimate feasibility for wide-spread nitrate removal. The methods appear sound and the conclusions appropriate. Several minor comments are listed below.

Authors state that the hydraulic gradient through the wall was greater near wells 6-10 vs wells 1-5. If this has been consistent throughout the life time of the wall, would not that suggest that the nitrate loading on the 6-10 half of the wall has been consistently greater than the other half? If so, were there any measurable differences between the 2 halves regarding remaining $\mathrm{C}$ stocks etc.? As it is not just time but nitrate load that should determine life expectancy for these structures, you may be able to compare the wall at two different long-term loadings.

This is an interesting idea, but it assumes that organic matter decomposition is limited by nitrate concentration. However, organic matter decomposition will 
continue in the absence of nitrate. While nitrate load may affect how much nitrate is removed by the wall, it will not affect $\mathrm{C}$ decomposition. No change.

Specific comments:

P3 156. Delete 2nd "available".

- $\quad$ The second available was deleted.

P 4 13. I think it inaccurate to state that "agricultural practices are aimed at minimizing denitrification" as I know of few if any practices specifically designed for this purpose. Many practices are designed to keep the root zone well aerated to benefit the crops growing on the soil. This does indirectly reduce denitrification, but aeration of roots is the design objective not reduction of denitrification.

- $\quad$ This phrase was perhaps a bit misworded in the manuscript. It was changed to "...agricultural practices are aimed at keeping the root zone aerated which indirectly reduces denitrification.

P5 151\&56. Interesting use of the pronoun "I". To which of the co-authors does this pertain? Perhaps "we" would be more appropriate.

- The "I" was changed to "we" in both cases.

P10 149 Change "gradients" to "gradient" to agree with verb.

- "Gradients" was corrected to "gradient".

P11 121. Stated here is that the wall nitrate concentration was $1.86 \mathrm{mg} / \mathrm{L}$ in June, but this is not the value shown in fig 2.

- $\quad$ Fig 2 has been fixed, the data point is now showing.

P12 135. Could you add in parentheses what the detection limit is for DEA?

- We did not test the machine for the detection limit for DEA. Our standard curves measured $\mathrm{N}_{2} \mathrm{O}$ down to $100 \mathrm{ppb}$, but we are unsure if the machine can detect concentrations below $100 \mathrm{ppb}$. We did have some zero concentrations which could have been between zero and $100 \mathrm{ppb}$. In any case, the majority of the $\mathrm{N}_{2} \mathrm{O}$ concentrations were above $100 \mathrm{ppb}$ and many of them were over $1 \mathrm{ppm}$. No change made.

Reviewer \#2: AGEE 6810 
This study evaluated the effectiveness of denitrification walls 14 years after establishment. Nitrate removal, microbial biomass $\mathrm{C}$ as well as denitrification enzyme activity was measured. The denitrification wall was found to be effective at removing nitrate 14 years after installation even though the total $\mathrm{C}$ and microbial biomass $\mathrm{C}$ decreased by about half of the initial levels. This manuscript falls within the scope of papers published by AGEE.

1. Please describe how the soil surface above the $1.5 \mathrm{~m}$ wall was maintained (cropped or bare or .).

- $\quad$ A sentence about this was added to M\&M section under study area.

2. There were many measurements made from samples collected within the wall. The samples collected outside the wall were either from upslope or downslope positions. It would have been informative if soils from the same position within the field which did not have the wall were collected and analyzed. These could have been the control treatments so that the DEA analysis from the wall could be compared to the background DEA assay from an unamended soil.

- $\quad$ Collecting samples from the same position in the field would have been informative, but it was not done for this study. We only collected groundwater samples from upslope and downslope in order to compare nitrate input vs. Output. Soil samples were only collected within the wall, as our main objective was to determine whether the denitrification wall was still functioning after 14 years in terms of nitrate removal. No change was made.

3. How much nitrate was converted to $\mathrm{N} 2 \mathrm{O}$ vs $\mathrm{N} 2$ in a denitrification wall? If nitrate is completely converted to $\mathrm{N} 2$, then this could be seen as a positive result from an environmental perspective. If however a significant amount of $\mathrm{N} 2 \mathrm{O}$ is released, then the denitrification wall converts one environmental contaminant (nitrate) to another (nitrous oxide). Some information/discussion on the relative proportion of denitrification products should be included.

- $\quad$ This is an interesting comment, but $\mathrm{N} 2 \mathrm{O}$ emissions were not tackled in this study. We did not measure $\mathrm{N} 2 \mathrm{O}$ concentrations and se we did not focus on this aspect. This was not determined in the current study, but there is a discussion of this in Schipper et al. (2010) review. No change made. 


\section{Specific Comments}

Pg 5 1 15-16 Exposure to aerobic conditions could also enhance N2O emissions.

- $\quad$ This is true and was added to the end of the sentence.

Pg 8 1 8-10 Please note that there are also problems associated with using chloramphenicol and the way to minimize this effect would be to use shorter incubation times without chloramphenicol. See Pell et al. 1996. Soil Biol. \& Biochem 28:393-398.

- We used chloramphenicol to make sure that the methods were the same as the previous papers on the denitrification wall. The previous studies (Schipper and Vojvodic-Vukovic, 1998; 2001) used chloramphenicol in the amendments for DEA. No change made.

Pg 11157 How does this SOC concentration compare to the background C contents of this soil?

- $\quad$ Schipper and Vojvodic-Vukovic (1998) reported that immediately after construction total carbon was $53 \mathrm{~g} \mathrm{~kg}-1$ (5.3\%) and that upslope total carbon was 1.6 $\mathrm{g} \mathrm{kg}-1(0.16 \%)$. The upslope total carbon is assumed to be the background $\mathrm{C}$ content of the soil. This was added into the M\&M study area section.

Pg 16160 Delete the word 'be'.

- "be" was deleted. 